\title{
Interpreting site formation processes affecting re-emergent cultural sites within reservoirs: A case study of St. Thomas, Nevada
}

Denyse Wyskup

West Virginia University

Follow this and additional works at: https://researchrepository.wvu.edu/etd

\section{Recommended Citation}

Wyskup, Denyse, "Interpreting site formation processes affecting re-emergent cultural sites within reservoirs: A case study of St. Thomas, Nevada" (2006). Graduate Theses, Dissertations, and Problem Reports. 888.

https://researchrepository.wvu.edu/etd/888

This Thesis is protected by copyright and/or related rights. It has been brought to you by the The Research Repository @ WVU with permission from the rights-holder(s). You are free to use this Thesis in any way that is permitted by the copyright and related rights legislation that applies to your use. For other uses you must obtain permission from the rights-holder(s) directly, unless additional rights are indicated by a Creative Commons license in the record and/ or on the work itself. This Thesis has been accepted for inclusion in WVU Graduate Theses, Dissertations, and Problem Reports collection by an authorized administrator of The Research Repository @ WVU. For more information, please contact researchrepository@mail.wvu.edu. 
Interpreting Site Formation Processes Affecting Re-emergent Cultural Sites within Reservoirs: A Case Study of St. Thomas, Nevada.

\author{
Denyse Wyskup
}

Thesis submitted to the Eberly College of Arts and Sciences at West Virginia University in partial fulfillment of the requirements for the degree of

\author{
Master of Arts \\ in \\ Geography
}

Steven J. Kite, Ph.D., Chair

Robert Hanham, Ph.D.

Trevor Harris, Ph.D.

Department of Geology and Geography

Morgantown, West Virginia

2006

Keywords: Reservoir, Erosion, Sedimentation

(C) 2006 Denyse Wyskup 


\section{ABSTRACT \\ Interpreting Site Formation Processes Affecting Re-emergent Cultural Sites within Reservoirs: A Case Study of St. Thomas, Nevada.}

\section{Denyse Wyskup}

The inundation of cultural resources due to the construction of dams as water retention mechanism is a global problem, affecting thousands of historic and prehistoric sites. Recent warming trends, in combination with increasing water usage from growing populations and urban expansion has initiated dramatic pool-level shallowing in many reservoirs, especially in the American Southwest, resulting in the re-emergence of inundated cultural sites. The "ghost town" of St. Thomas, Nevada, represents one example of a site that was impacted in this manner. This historic settlement is one of many hundreds of sites that became submerged when Boulder Dam was constructed to impound the waters of the Colorado River to create Lake Mead reservoir in 1935;

providing irrigation, hydroelectric power and flood control in the lower Colorado River basin.

This research identifies those processes governing and manipulating site formation and the stability of remaining structural features. Field investigation, soil analysis, $X$ ray diffraction, examination of historic gauge records and aerial imagery indicates that St. Thomas, and perhaps other cultural sites located within the down-draw boundary of reservoirs, are susceptible to severe degradation from mechanical lacustrine wind-wave action, biologic intrusion and structural instability caused by shrink-swell sediments. Preservation and conservation measures for cultural sites located within these environments are not well developed; the data collected and the results generated from this research are valuable tools in formulating and constructing conservation plans for these sites. 


\section{Acknowledgements}

I want to thank the Cultural Resource Team at Lake Mead NRA for all their help and support while conducting this research. Their knowledge and manpower were integral to completing this research. 


\section{Table of Contents}

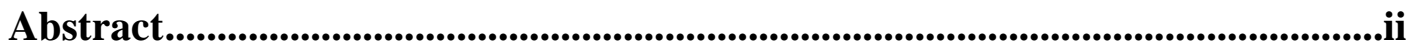

Acknowledgements ..........................................................................................iii

Table of Contents ........................................................................................................................iv

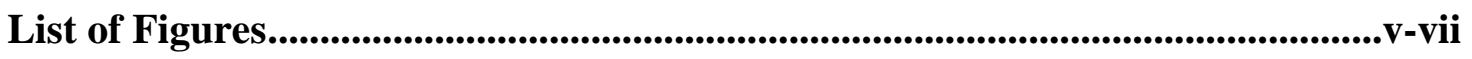

List of Tables ..............................................................................................................viii

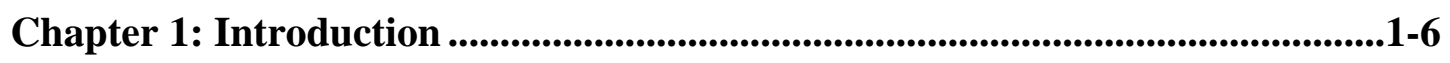

Chapter 2: Background St. Thomas, Nevada.........................................................7-13

Chapter 3: Texts Consulted and Research Design.............................................14-21

Chapter 4:

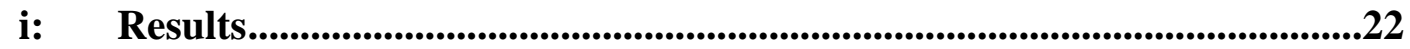

ii: $\quad$ Reservoir Filling and Sediment Accumulation........................................22-34

iii: Water Level Fluctuation...............................................................................34-37

iv: Field Observations.................................................................................38-60

v: Submerged Environment ......................................................................60-63

vi: $\quad$ Variables Contributing to Erosion.................................................................63-77

Discussion.................................................................................................................78-80

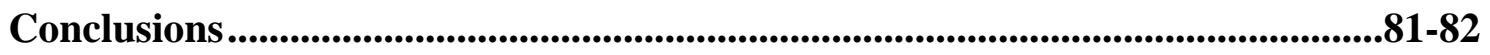

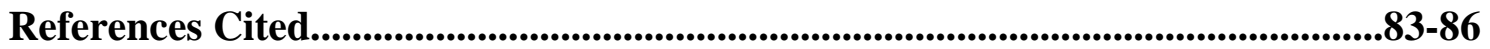

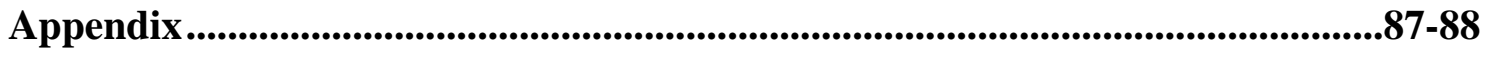




\section{List of Figures}

Figure 1. Late 1800s homesteads at St. Thomas, Nevada.....................................2

Figure 2. Satellite image of Lake Mead and the upper and lower Colorado River drainage basins

Figure 3. Landsat image of Lake Mead with labeled areas of interest significant to this research .7

Figure 4. Portion of the San Pedro \& Los Angles Railroad circa 1925 10

Figure 5. Mercantile store 1929; one of several local businesses operating at St. Thomas during the community's economic boom .

Figure 6. St. Thomas Point overlooking St. Thomas and Lake Mead .17

Figure 7. Remaining re-emerged walls and remnants of the blacksmith shop at St.Thomas 18

Figure 8. Geology of the Overton Arm ....................................................................24

Figure 9. Convergence of Colorado River and Lake Mead in Pierce Basin......28 Figure 10. Map of the thickness of post-impoundment sediment in Lake Mead.

Figure 11. Sidescan-sonar image of the town of St. Thomas, which was submerged shortly after Lake Mead started to fill. .33

Figure 12: Bench mark on 1932 topographic map indicates base surface at St. Thomas as $1150 \mathrm{ft}(\sim 350 \mathrm{~m})$. .35

Figure 13. Historic water level fluctuations at Lake Mead NRA

Figure 14. Gentry Hotel, May $13^{\text {th }} 1934$.............................................................39

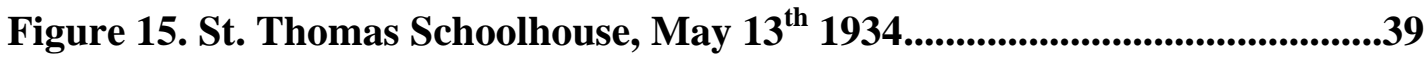

Figure 16. Gentry Store, circa 1900..........................................................40

Figure 17. Gentry Hotel.......................................................................................40

Figure 18. Gentry Store .........................................................................................41

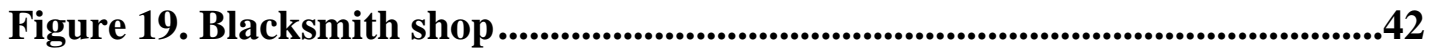

Figure 20. Spalling on the Gentry house.................................................................42

Figure 21. Plan view of the blacksmith shop indicating placement of Test Unit 1 
Figure 22. Plan view of Test Unit 1 at terminus of excavation.

Figure 23. Test unit one terminus of excavation..

Figure 24. Portion of the foundation of the St. Thomas Schoolhouse, looking southwest toward Lake Mead.

Figure 25. Plan of St. Thomas Schoolhouse indicating approximate location of Test Unit 2.

Figure 26. Plan view of Test Unit 2 at terminus of excavation ......................49

Figure 27. Test unit two at terminus of excavation..............................................49

Figure 28. St. Thomas Point overlooking re-emerged area................................50

Figure 29. Aerial photo taken during tamarisk leaf-off. ......................................50

Figure 30. Site map of St. Thomas depicting exposed cultural features, tested areas, excavated test units and ground patterns ...............................52

Figure 31. Two level home (left) where deposits were in excess of $63 \mathrm{~cm} . . . . . . . . .53$

Figure 32. Oil changing pit (right) where deposits were in excess of $63 \mathrm{~cm} . . . . . .54$

Figure 33. Dimpling pattern observed in the foreshore region. ............................55

Figure 34. Cracked ground observed further backshore.....................................56

Figure 35. Aerial photo acquired in 1925 by the Fairchild Corporation prior to the submersion of St. Thomas and surrounding area. .........................58

Figure 36. Gentry garage..................................................................................60

Figure 37. Thermal stratification of Lake Mead during summer months .........61

Figure 38. Biological zones associated with the physical structure of lakes...... 62

Figure 39. Homestead removal circa 1935. ..................................................64

Figure 40. Rising waters on highway 91. ..................................................64

Figure 41. Aerial photo taken June 2003...............................................................67

Figure 42: Aerial photo taken June 2003.............................................................67 
Figure 43. Aerial photo taken June 2003.

Figure 44. Cracking on schoolhouse wall .......................................................70

Figure 45. Foundation separation at Gentry Store.........................................70

Figure 46. Clay mineral peaks and patterns for sediment samples; d-spacing in angstroms.. ................................................................................................72

Figure 47. Clay mineral peaks and patterns for collected soil samples after ethylene glycol treatment; d-spacing in angstroms.............................72

Figure 48. Sample TT_3, from Feature 6, d-spacing, peaks for identified minerals. .73

Figure 49. Sample TT_3_A, from Feature 6, d-spacing and peaks for identified minerals after ethylene glycol treatment.

Figure 50. Sample B_51, from the garage pit, d-spacing and peaks for identified minerals. .74

Figure 51. Sample B_51_A, from the garage pit, d-spacing and peaks for identified minerals after ethylene glycol treatment.

Figure 52. Figure 48: Sample DS_24, from Test Unit 1 A stratum, d-spacing and peaks of identified minerals. . .75

Figure 53. Sample DS_24_A, from Test Unit 1 A stratum, d-spacing and peaks of identified minerals after ethylene glycol treatment. . .75

Figure 54. Sample E_1, from Test Unit $1 \mathrm{C}$ stratum, d-spacing and peaks of identified minerals. . .76

Figure 55. Sample E_1_A, from Test Unit 1 C stratum, d-spacing and peaks of identified minerals after ethylene glycol treatment. 


\section{List of Tables}

Table 1. List of dams located on the Muddy and Virgin Rivers including tributaries; Hoover and Glen Canyon dams are included for

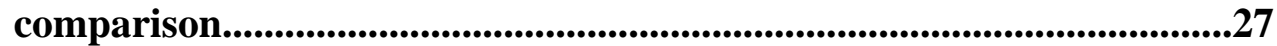

Table 2. Percent of gravel, sand, silt and clay fraction in each soil sample........56

Table 3. Soil sample origins and designated test numbers.................................71 


\section{Introduction}

\section{Chapter One}

Dams have been used for decades within the United States as water retention and diversion mechanisms. Data gathered by the International Rivers Network and National Inventory of Dams (NID) indicate that the number of dams within the United States is between 76,000 and 2.5 million (Brink, 2004). The extensive range between these figures results from discrepancies concerning approximate height and storage capacity required to categorize structures as dams. Most dams in the United States were constructed in a 50 year time span between 1920 and 1969; one-quarter of all existing dams were built in the 1960s (Graf, 2005).

The damming of Boulder Canyon, now known as Hoover Dam, marked a new era in dam construction. These “very large structures,” with reservoir capacities greater than $1,233,480,000 \mathrm{~m}^{3}$, were constructed to increase the economic viability of areas with river resources (Graf, 2005). However environmentalists, conservationists, engineers and scientists now recognize that the socio-economic benefits reaped from dams also impede a river's natural ability to convey water and sediment, alter the equilibrium of biologic ecosystems and fluvial systems, destroy cultural resources and displace human populations.

Tens of thousands of historic and prehistoric cultural sites have been submerged throughout the United States through the construction of water retention dams; the "ghost town” of St. Thomas, Nevada, represents one example of a site that was impacted in this manner (Figure1). The historic settlement of St. Thomas is one of many hundreds of cultural sites that became submerged when Boulder Dam was constructed to create Lake Mead reservoir in 1935. However, due to water level fluctuations and pool level 
shallowing, this historic site has re-emerged, in turn exposing the remaining cultural features to erosional elements that irreversibly degrade and compromise the structural integrity of remaining features. This thesis focuses on identifying those processes and the variables controlling site formation and degradation at St. Thomas during submergence and re-emergence phases. This information is then used to develop and prescribe conservation measures to ensure site stability.

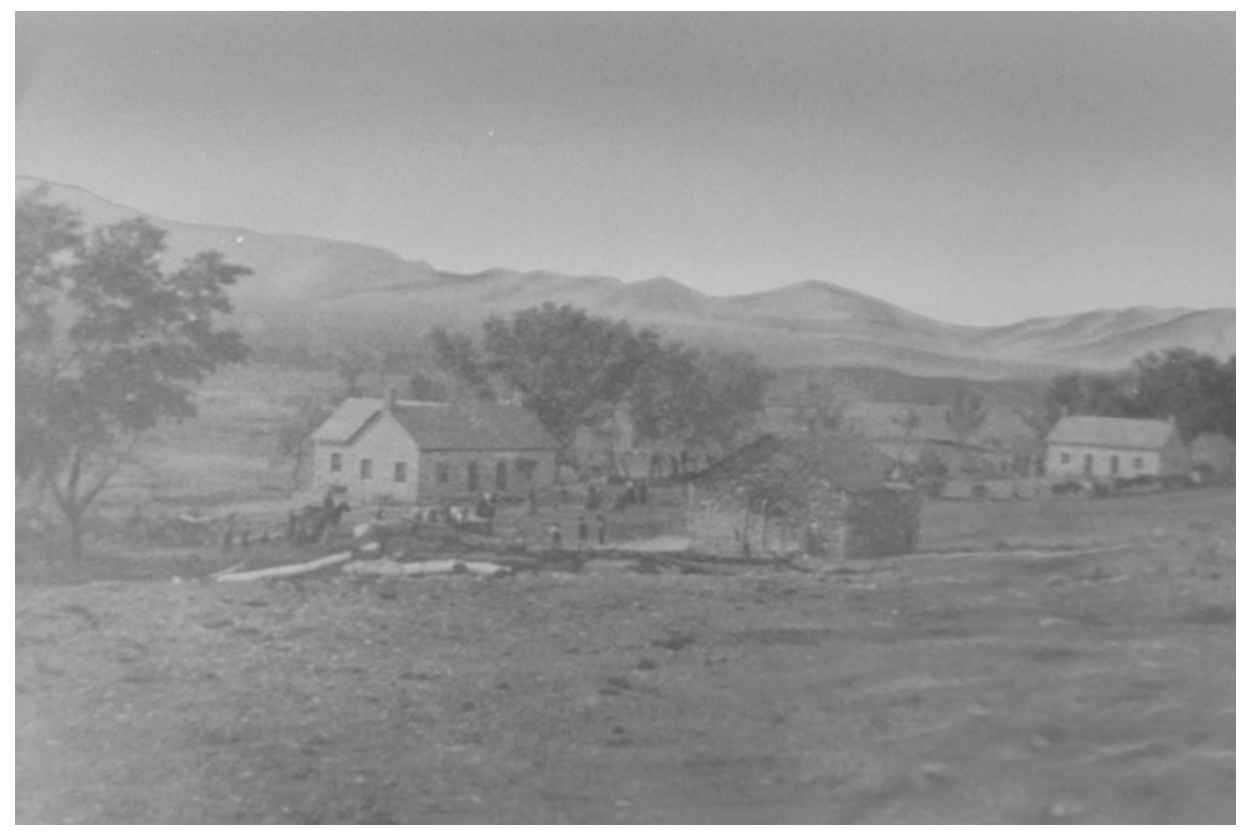

Figure 1: Late 1800s homesteads at St. Thomas, Nevada. Photo source: University of Las Vegas Lied Special Collections Library.

\section{Purpose for Research}

Dam construction is a global phenomena and the utilization of these man-made features serve multiple objectives, including rectifying environmental predicaments humans have created by occupying areas where dense populations are not suited for long term occupation, as in the American Southwest. The purposes for constructing dams within the Colorado River drainage basin are diverse and includes energy generation, water flow regulation to prevent flooding and recreation. 
The adverse effects dams place on ecosystems was first noticed by ecologists and environmentalists such as Edward Abbey (1971), who provided insight into the construction of Glen Canyon Dam, which inundated one of the United States' most spectacular canyons and desert ecosystems. These scholars ascertained the negative impacts that dams would have upon the environment, though only recently through the formation of organizations such as the World Commission on Dams, has there been advocacy to comprehend the cultural losses the world is experiencing as a result of reservoir inundation and fluctuation.

Although dams have been in use for centuries within the United States, the regulations overseeing cultural heritage management were initiated only recently with enactment of the1960 Reservoir Salvage Act, which required construction agencies spend funds on the mitigation of impacts to archaeological sites. The Historic Preservation Act of 1974, later superceded this act.

Dams will continue to be used as a mechanism to increase human sustainability within marginal or depleted environments. The key to rectifying cultural heritage mismanagement and avouch preservation and conservation of cultural heritages in peril of flooding and submersion is the initiation of preservation methods that are cost and time effective.

Creating and implementing cost and time-effective solutions to unstable cultural sites requires an understanding of the sedimentation and erosional processes affecting site formation during the evolution of reservoirs, from impoundment to submergence and then re-emergence. Lenihan et al. (1981) specifies that the evolution of reservoirs occurs in two specific impoundment regimes: pre-impoundment, in which dam construction and 
land-use are the primary activities degrading cultural sites; and post-impoundment, which is characterized by inundation and alteration to a laucustrine environment subject to erosional processes caused by water-level fluctuations.

Episodic re-emergence events at St. Thomas create unique impact sequences not seen in reservoirs with more static water levels. Typically, water level fluctuation in reservoirs is manually controlled through periods of water release that correspond with increased seasonal recharge or downstream water shortages. Lake Mead derives 95 percent of its recharge from spring thaw melting of snow accumulations at the headwaters of the Colorado River.

To date, a decrease in winter accumulation and an increase in water usage combine to cause fluctuating, but long term decline of levels in Lake Mead and other reservoirs on the Colorado River, such as Lake Mohave and Lake Powell. In addition to examining the mechanical stresses structures are exposed to from active water level fluctuations, this research will also explore the biologic stresses that structures induce as a result of reservoir down-draw. One of the biological factors reducing site stability and causing structural degradation derives from Tamarix ramosissima.

Tamarix ramosissima, a member of the Tamarisk family and also referred to as saltcedar, is a deciduous invasive species found within floodplains, riparian areas, wetlands and lake margins throughout the western United States (Carpenter,1998). This woody plant species can either be branched shrubs or small trees that reach up to $5 \mathrm{~m}$ in height. Once established, tamarisk can withstand extreme environmental conditions and will choke out native species such as cottonwood and willow; forming monotypic stands (Grubb et al., 2002). 
The origins of tamarisk in the western United States is uncertain, but popular belief denotes its arrival in California in the early 19th century from East Coast nurseries who where importing the exotic from Eurasia. This exotic was cultivated in the United States as an ornamental shrub and valued for its use as a windbreak and stabilization mechanism for eroding stream banks (Carpenter, 1998). Not until the 1920s was this species recognized as invasive.

\section{Objective of Thesis}

The variables discussed thus far alter site stability and formation at St. Thomas through constant transitions from static to active states. This thesis explores the processes at work that degenerate site and structural stability, and influence site formation. Conducting a case study of St. Thomas, Nevada, is integral to understanding how degradational processes operate. Accomplishing this research requires examining the mechanical-lacustrine, biologic and human processes that govern and manipulate site formation. Examining these elements will aid in identifying the processes at work that irreversibly degrade the remaining structural features at St. Thomas. It is anticipated that the data generated from this research will be used as a tool or guide to develop preservation and conservation measures, which can be implemented to prevent and retard the degradation of sites in similar environments.

The discussion thus far outlines the need to establish conservation parameters for cultural sites located within degradational environments and specifically those located within the down-draw boundary of receding reservoirs. The re-emergence of inundated sites will continue as long as the prevailing environmental conditions in the arid 
Southwest persist, and may increase in geographic significance as dam removal becomes a favored stream and ecosystem restoration measure.

The questions explored within this thesis examine the mechanical-laucustrine, microerosional, biologic and human processes threatening site stability, and, in turn, revealing available options to deterring site degradation. The fundamental research questions for this analysis will address the following:

(i) What processes and variables are most destructive to site stability?

(ii) How has the hydraulic regime within Lake Mead changed since initial impoundment?

(iii) How many times, and for what lengths of time, has St. Thomas re-emerged?

(iv) What are the possible sources contributing to sedimentation at St. Thomas?

(v) Is it possible to determine sedimentation rates at St. Thomas, if so what are the rates?

(vi) What state of stability characterizes the underwater environment during submersion?

(vii) What is the structural strength of the remaining features?

(viii) At what scale are erosional processes operating? 


\section{Chapter Two}

\section{Background: St. Thomas, Nevada}

Lake Mead National Recreation Area NRA (Figures 2 and 3) encompasses 1.5 million acres and is located in the Mojave Desert within the Basin and Range physiographic region. Although this region is known for its extreme climate and topography, evidence indicates that human occupation occurred here as early as the Archaic period, sometime after 3000 B.C.. Native Americans continuously occupied the region until the 18th century A.D. when the area opened up to westward expansion and migration from the eastern United States (McClellan et al., 1980).

This area was dominated by two eras of immigration; first by the Mormon settlement of the Moapa Valley and the establishment of the Muddy Mission; followed by the era known as "the Gentile period" that led to the procurement of all land holdings by nonMormons. This thesis focuses on the era since the citizens of St. Thomas were forced to relocate after the United States government declared eminent domain on their real estate. 


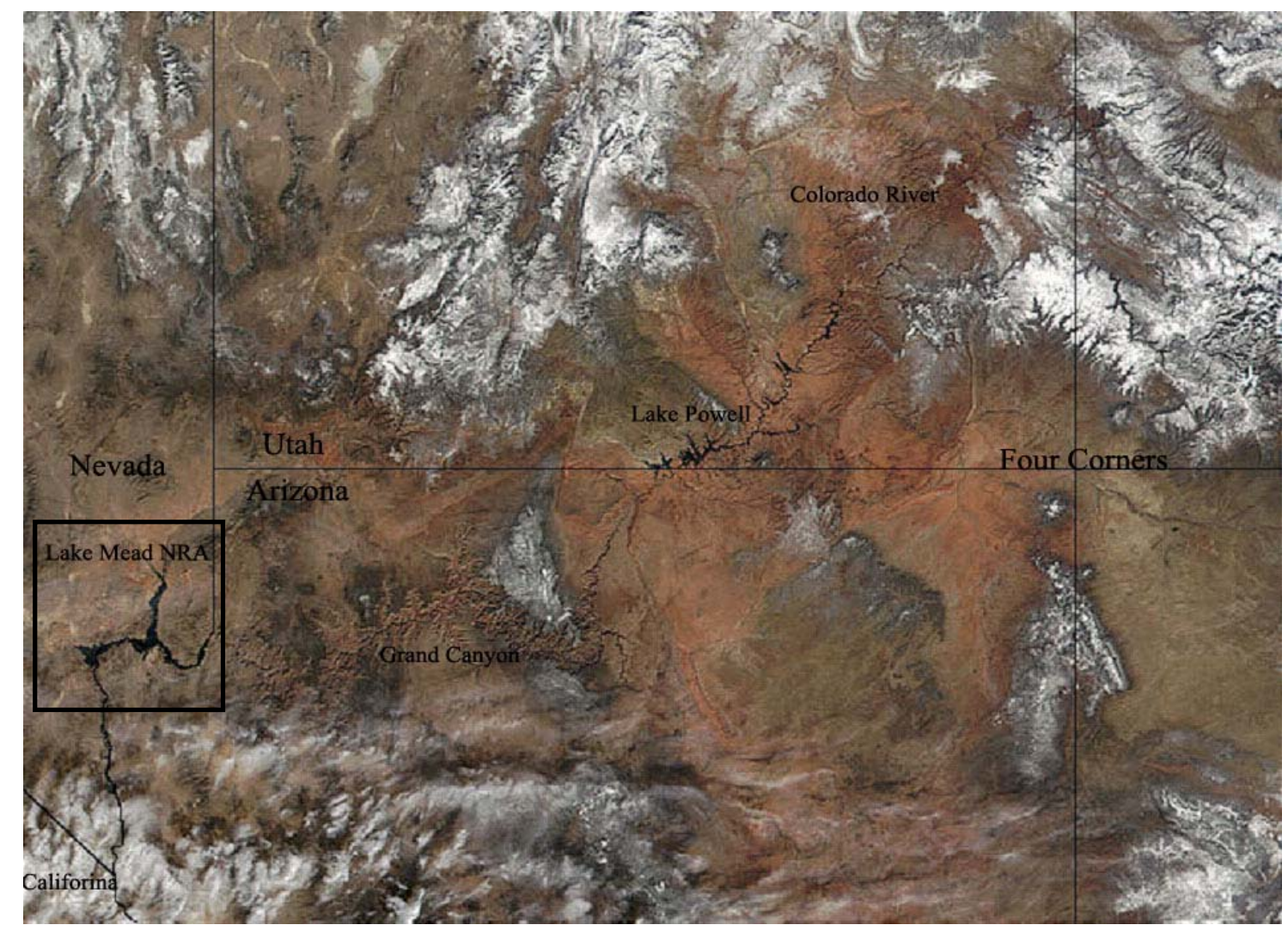

Figure 2: Satellite image of Lake Mead and the upper and lower Colorado River drainage basins. Photo source: U.S. Geological Survey National Map, 2005.

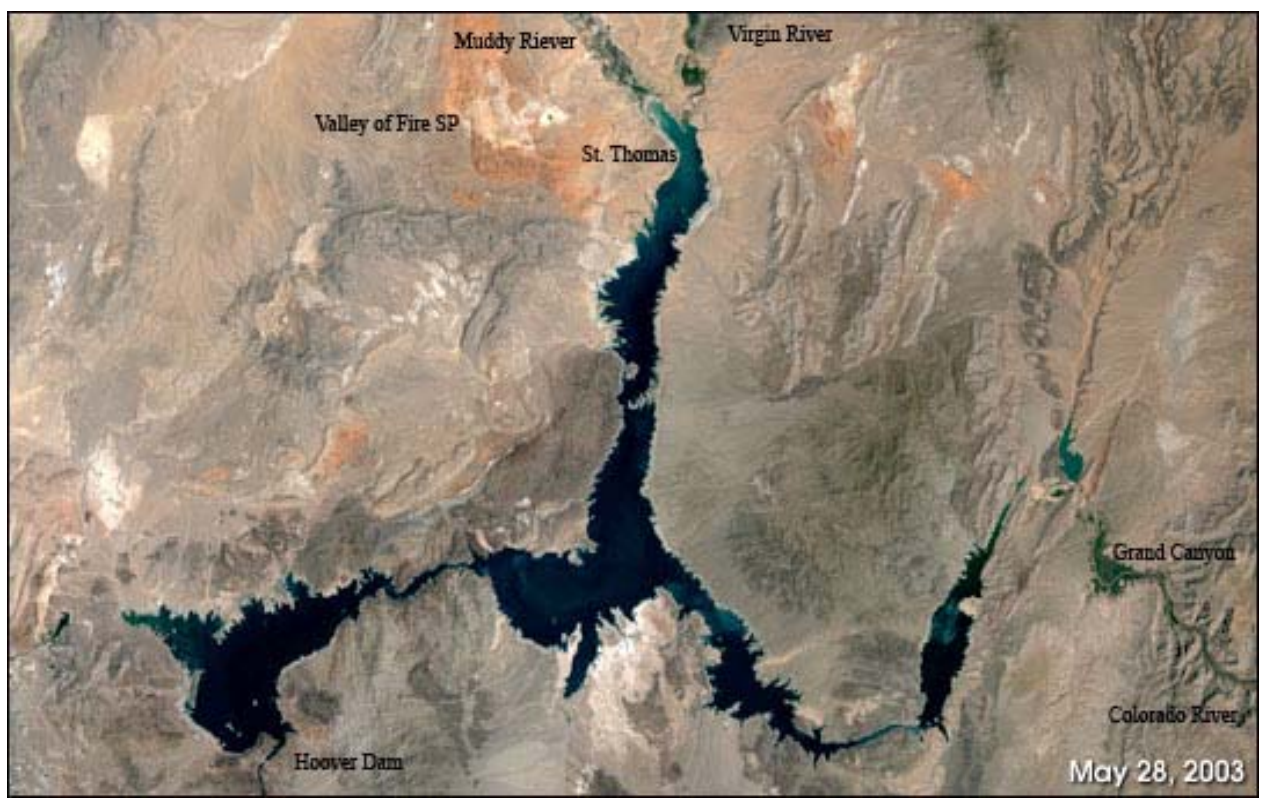

Figure 3: Landsat image of Lake Mead with labeled areas of interest significant to this research. Photo source: Allen and Simmon, 2003. 
St. Thomas was founded in January 1865 at the confluence of the Virgin and Muddy rivers (Figure 3). Confusion amongst the settlers persisted as to the true location of St. Thomas with respect to federal territorial boundary and arguments ensued over whether St. Thomas was located within Utah, Arizona, or New Mexico Territory. The Mormons at the time thought the area to be located within Washington County, Utah.

The settlement acquired its name after Thomas S. Smith, “the presiding elder” of the Mormon Muddy Mission, who sought to achieve objectives set forth by Brigham Young. Along with St. Joseph (now Logandale) and Overton, St. Thomas was one of three towns established within this valley to fulfill Young's westward vision to establish selfsustaining "family" communities within the region, free from the discrimination and inequality they received from their former neighbors and the United States government. St. Thomas's role in this vision was to make a pre-emptive claim to the Muddy Valley region, to grow cotton to ensure Mormon self-sufficiency and to establish a river route to supply the colonists and return goods to Zion (McClellan et al., 1980). Life within this rural settlement was rigorous due to the extreme environmental conditions, but the community persisted in establishing gardens, orchards, vineyards, and grain and cotton fields.

During February 1866, the original settlement of St. Thomas was moved $\sim 4 \mathrm{~km}$ northwest and surveyed to accommodate roughly 45 families. The question as to the location of St. Thomas with respect to county and territory was assumed to have been resolved in 1866 when the federal government designated the town post office to be within Washington County, Utah. The year 1867 brought uncertainty to the community when the jurisdiction of St. Thomas was once again placed in question by the federal 
government, for the resurvey by the U.S. government instituted St. Thomas as the seat of Lincoln County, Nevada. Life carried on until an official survey conducted in 1870 resolved the boundary conflict and officially placed the town within Lincoln County, Nevada (McClellan et al., 1980). Notification from officials of Nevada to the citizens of St. Thomas stated that any person residing within the community who wished to remain, would be required to pay all back taxes for the years 1867 to 1870 in gold coin, which the Mormon settlers lacked.

The majority of citizens chose to leave after Brigham Young visited the community and released the settlers from their calling due to his disappointment over the viability of the surrounding country and the attitude of the federal government towards the Mormon settlers. Daniel Bonelli and his family were the sole Mormon settlers who chose to remain in St. Thomas. Bonelli established a ferry route at the confluence of the Virgin and Colorado Rivers to supply salt, feed, and food provisions to the Eldorado miners located on the Colorado (McClellan et al., 1980).

The procurement of these properties marked the beginning of the Gentile period at St. Thomas. By 1871, most of the original Mormon settlers had moved on. Much of the abandoned land was bought by the Jennings family, who harvested the left-behind crops and built on the prosperity established by the original Mormon settlers (McClellan et al., 1980). St. Thomas remained a strong agricultural community and other industries, such as salt and ore mining, prospered until the town's evacuation and eventual submersion. Together, agriculture and mining aided in establishing St. Thomas as an integral stop on the Salt Lake City-Los Angeles Arrowhead Trail. This road subsequently became State Highway 91 and was the primary connector of these two destinations at the turn of the 
$20^{\text {th }}$ Century. Track was laid in 1911 for a spur of the San Pedro \& Los Angeles Railroad to connect and transfer goods from St. Thomas to the surrounding communities (Figure 4).

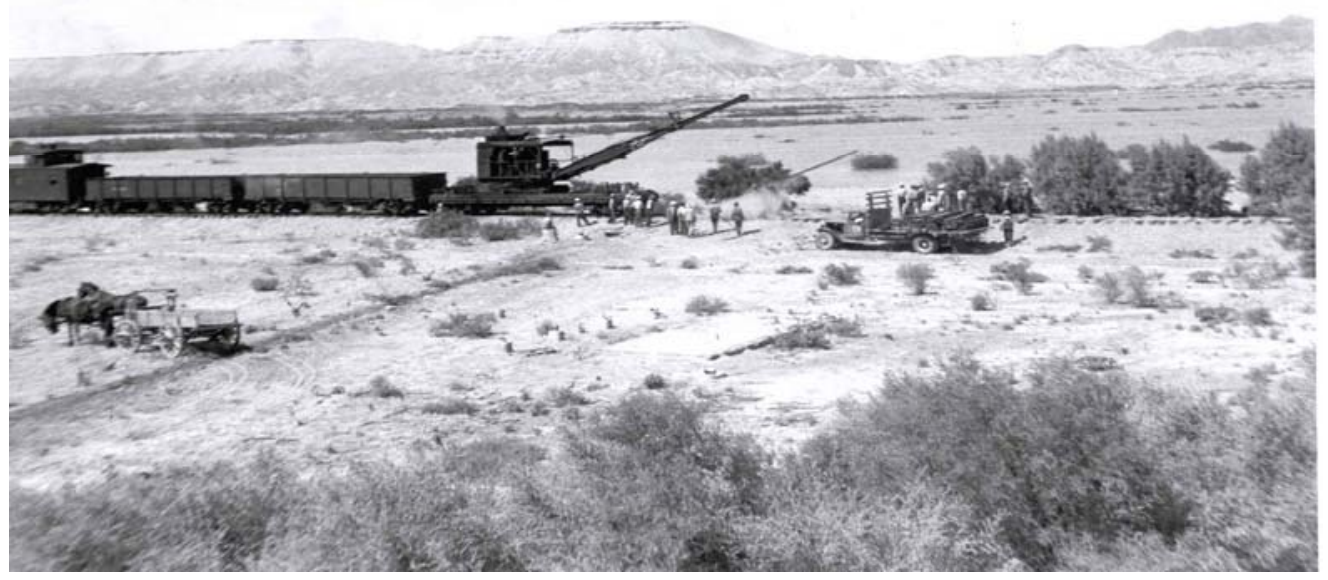

Figure 4: Portion of the San Pedro \& Los Angles Railroad circa 1925. Photo source: University of Las Vegas Lied Special Collections Library.

By 1918, St. Thomas was a thriving community with an economy that supported several local businesses such as the Gentry Store, R. Hanning Grocery Store, Gentry Hotel, William Sellers Café, Howell Garage and Rox Whitmore Meat Market (McClellan et al., 1980). Mercantile stores were also found throughout the community (Figure 5) (McClellan et al., 1980). Foundations of many of these structures remain today. This date also marked the peak year of commerce for St. Thomas, but was then followed by 20 years of gradual business stagnation and eventual abandonment. 


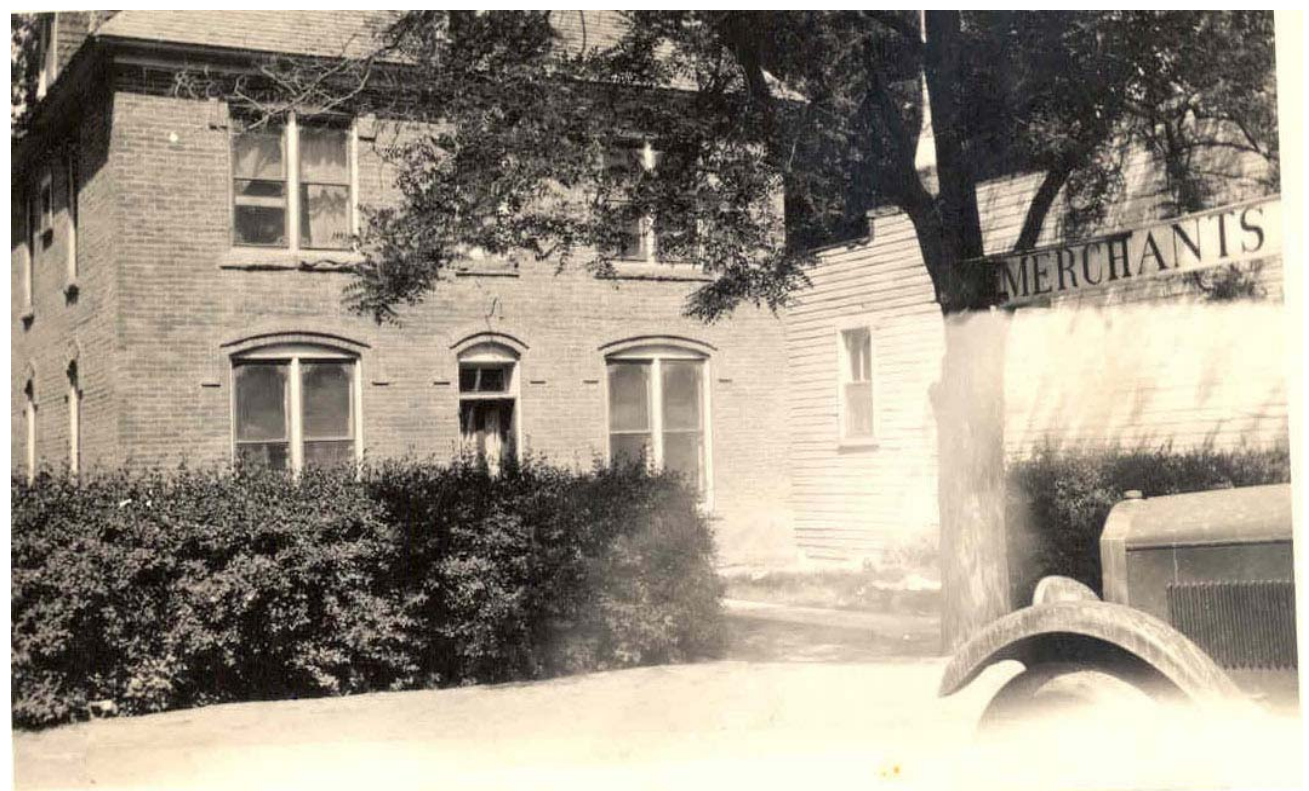

Figure 5: Mercantile store 1929; one of several local businesses operating at St. Thomas during the community's economic boom. Photo source: University of Las Vegas Lied Special Collections Library.

This downturn in economic prosperity was brought about by three events: the abandonment of Highway 91 as the primary Salt Lake City-Los Angeles connector, the announcement of plans for the Boulder Dam Project, and a decline in copper prices that led to mine closures and cancellation of railroad freight services to St. Thomas (Hafner, 1967). Eminent domain was declared on all landholdings in St. Thomas and by 1926 the government began appraising properties. To the dissatisfaction of landholders, the consensus held amongst citizens was that properties were estimated grossly under market value; by 1932 all holdings were United States property (Hafner, 1967).

The St. Thomas post office continued to function until June 11, 1938, when the post master closed the office by marking the last pieces of mail with cancellation stamps "last day-covers”. Myth has it that the machine was then thrown into Lake Mead (Hafner, 1967). Hugh Lord, the service station owner, is credited as being the last citizen to leave 
St. Thomas; he reluctantly left during the night when he awoke to find rising waters surrounding his bed (Hafner, 1967). 


\section{Chapter Three}

\section{Texts Consulted and Research Design}

\section{Reservoir Processes and Inundation- Texts Consulted}

The body of literature encompassing the preservation and effects of inundation and reemergence on cultural resources in response to reservoir construction and down-draw is sparse due to the relatively recent onset of interest. The earliest published study conducted by U.S. National Park Service (1981), entitled the "National Reservoir Inundation Study,” examined the erosional variables that compromise site stability. This report was the first attempt by any American government or private agency to examine the effect of continuous and intermittent freshwater inundation upon prehistoric and historic cultural resources. This study was more recently supplemented by research sponsored by the World Commission of Dams and published within the report Dams and Cultural Heritage Management (2000) and a Journal of Geomorphology special edition (Bayer, 2005), dedicated to researching the influences dams place on fluvial systems. These resources provided many secondary sources on reservoir erosion and site stability. The yet to be released book "Damming the Past" by Brandt and Hassan (in press), who are also authors in the World Commission of Dams Report, promises to be a valuable resource.

The mechanics and processes functioning within reservoirs are diverse; therefore, literature pertaining to reservoir hydraulics, such as Koelzer (1969) and Davis and Sorenson (1969), were used as aides to deduce and decipher historic and current site formation processes at work within the reservoir. This literature was valuable in understanding how sediment dispersion within reservoirs is dependent upon numerous 
variables such as flow velocity, particle size, density of suspended sediments, water temperature and chemistry of inflowing streams. Leopold (1994) and Knighton (1998) were key sources used to understand possible origin, transport and storage paths of sediment entering Lake Mead.

Erosional processes at St. Thomas influence site formation and structural stability of the remaining features. Brown et al. (1999) was a valuable resource used to decipher the mechanical processes operating at St. Thomas during episodes of pool-level shallowing. This source was used to identify and understand wind-wave, seiche, and beach processes at work during periods of re-emergence. Carpenter (1998) and Grubb et al. (2002) were used as tools to identify and interpolate the negative biologic factors, namely tamarisk, influencing site formation and erosion.

\section{Fieldwork \& Data Collection}

Reservoirs differ from one another, so it is difficult to draw generalizations from one reservoir that can be applied to others. Adequate understanding of the processes affecting site formation within a human-made reservoir requires a broad examination of its morphological characteristics, such as reservoir shape, shoreline development, and sedimentation. In addition, an overview of the limnological characteristics within Lake Mead's Northern Arm, where St. Thomas is situated, was undertaken to determine the physical, chemical, and biological processes influencing environmental conditions at St. Thomas.

The successful accomplishment of the research objectives requires field survey of the re-emerged portions of St.Thomas, placing random soil probes where deposits remain intact and excavating two $1 \mathrm{~m}$ by $1 \mathrm{~m}$ test units. Two field sessions were planned and 
carried out. A May 2005 field session focused on project feasibility, permit requirements, establishing communication with park officials and preliminary survey.

Field investigations conducted in January 2006 concentrated on discerning the processes at work that distributed sediment at St. Thomas, conducting assessments on the conditions of the remaining structures and the analysis of historic 1925 aerial photography of St. Thomas on reserve at Whittier College. Soil probes were placed in areas where sediments remain, using an Oakfield soil probe with a diameter of $2.9 \mathrm{~cm}$ and beginning in the foreshore area (approximately $3 \mathrm{~m}$ from the present shoreline) and moving in a southwesterly direction toward St. Thomas Point (Figure 6).

Probes were placed based on the following criteria:

i. At places where changes in soil pattern, i.e. cracking or dimpling, were visible.

ii. Where texture changes were suspected or identifiable.

iii. Where increased distance from water, to determine depth and extent of sediment moisture retention after re-immersion.

iv. By walled structures that contained sediment.

v. Where significant alterations in slope were observed.

Each probe and test unit location were mapped using a handheld Trimble GeoXT Geographic Positioning System (GPS) and downloaded into a Geographic Information Systems (GIS) database created by the cultural resource management team at Lake Mead NRA for inclusion in the final site map. 


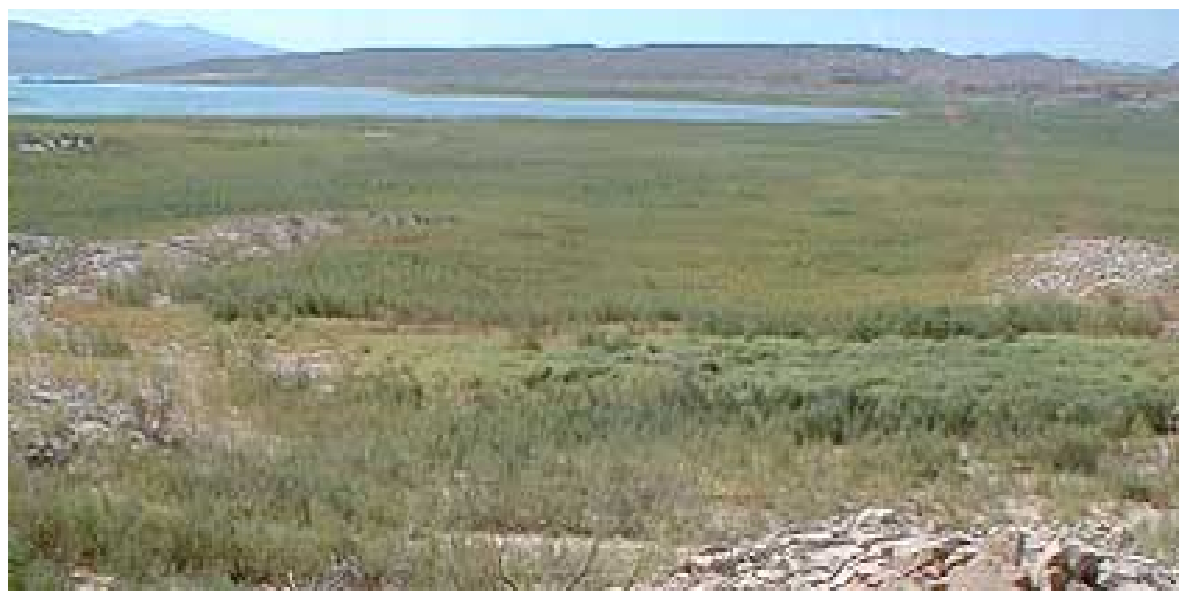

Figure 6: St. Thomas Point overlooking St. Thomas and Lake Mead. Photo taken May 2006.

The identification of intact deposits at St. Thomas is complicated by historical reservoir down-draw. The placement of test units was limited to areas containing intact deposits. Test Unit One was placed within a small, walled structure known as the blacksmith shop (Figure 7). The second unit was placed in the St. Thomas Schoolhouse to determine the extent of deposition and small-scale erosion in large structures. 


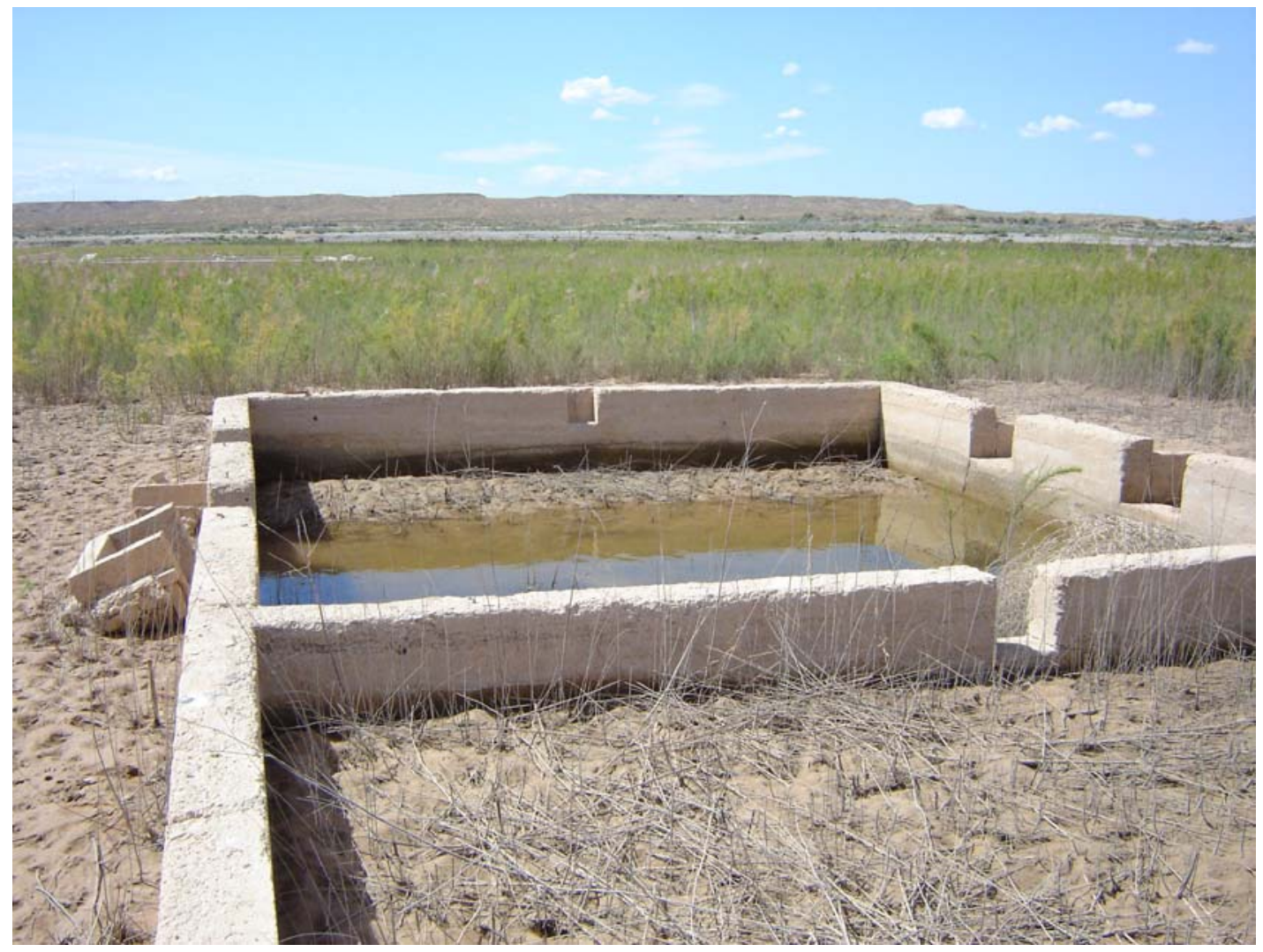

Figure 7: Re-emerged walls and remnants of the blacksmith shop at St.Thomas. Note sediment accumulation within the structure. Photo taken May 2005.

The procedures for excavating the $1 \mathrm{~m}$ by $1 \mathrm{~m}$ test units were as follows. Excavation of a test unit proceeded with shovel and trowel, following natural soil breaks until a buried A strata, the original settlement soil, was exposed. Soil samples (100 ml) were collected from each unit to determine smectite content through X-ray diffraction. All sediments were screened through $0.60 \mathrm{~cm}$ mesh, all cultural material found within the unit was noted and placed back within the unit once excavation ceased; no artifacts were collected. Each unit was photographed with digital and SLR color cameras and mapped using a handheld Trimble GeoXT GPS. Wall profiles and plan views were drawn for two walls within each test unit. All collected data and information were made available to Lake Mead NRA. 
Excavating these units aided in clarifying the origins of soil deposits, the extent of deposition, the depth of intact deposits, and the presence and extent of erosional activity. One by one meter test units established the vertical sequence of strata, grain size, texture and color. These variables are evidence of previous periods of emergence.

An understanding of the processes depositing these sediments is integral to understanding sediment transport, reservoir dynamics and flow processes within the hydraulic system of Lake Mead's hydraulic system. Comparisons also were made to determine if sedimentation patterns, texture and depth exist between facies identified in the 1999 to 2001 lake floor surveys conducted by the Woods Hole Division of the U.S. Geological Survey (Twichell et al., 2003). Terrestrial survey of the site provided data revealing the observable relationships between site stability, status and composition of structures, dominant mechanical, biological and human impact agents, and alterations to landforms.

Field research conducted during the January field session also included travel to Whittier College, Los Angeles, California, to view the 1925 aerial photos of St. Thomas. Reference was made to these images in U.S. Geological Survey Professional Paper 295 (Gould, 1948) which, listed the Fairchild Corporation as the company contracted by the Bureau of Reclamation to document lands to be submerged after Hoover Dam became operational. Restructuring of the Fairchild Corporation during the 1980s phased out the Division of Aerial Acquisition and scattered the archived photos to various museums and academic institutions throughout the United States. A web search indicated the flight line acquired in 1925 was housed at Whittier College, California. 
In addition to investigating the mechanical, biologic, and human agents impacting the cultural site, consideration also was given toward the resistance of remaining structures. For purposes of this paper, resistance is defined as the ability to withstand or resist erosional forces based upon the structures overall composition.

\section{Clay Mineral Analysis}

Testing for large-scale erosion resulting from accumulated soil deposits within features was performed using particle size analysis and X-ray diffraction (XRD). Procedures outlined by Kite and Bell (1992) were used to identify and separate clay, silt and sand fractions from each sample. Once the clay fraction was isolated from the samples, procedures prescribed by Warshaw and Roy (1961) were used to prepare and mount samples for XRD analysis. XRD was used to determine the presence of smectites, also known as shrink-swell clays, within collected soil samples. Smectites are a group of phyllosilicates minerals that form 2:1 clays, with two tetrahedral layers sandwiching a central octahedral layer. Expansion of the clay occurs due to a potassium deficiency that weakens the bonds between layers, allowing water to penetrate intermediate layers and increase interlayer space; also known as d-spacing (Warshaw and Roy, 1961).

$\mathrm{XRD}$ is the process of measuring the scattering of X-rays projected onto a crystal, and thereby producing a diffraction pattern that reveals the structure or d-spacing in the crystal lattice. XRD was run twice on each sample, prior to introducing ethylene glycol as an expansion molecule and after the ethylene glycol treatment. This procedure identifies the clay minerals according to similarities in the d-spacing of known clay minerals. 


\section{Reconstructing Water Level Fluctuation}

To identify episodic fluctuations in water level, historic Bureau of Reclamation gage data kept on file at Hoover Dam were utilized to reconstruct a time sequence of lake elevation and thereby allowing the reconstruction of down-draw and low-water periods that revealed incidences or periods when St. Thomas was re-emerged.

Understanding the evolution of the reservoir landscape depends on the quality of the: aerial photography, identification and location of the remaining structures and their condition prior to submergence, pre-submersion and current contour maps, the examination of sedimentation patterns, and historic water-level records for Lake Mead.

Pre-submersion and current contour maps, on record at the University of Las Vegas's Lied Special Collections Library and U.S. Geologic Survey National Map, an interactive web based map data source, in addition to aerial photography located at the Fairchild Collection and on-line at Earth Resources Observation System, aided in understanding the evolution of the landscape as a product of geomorphic processes and human land-use. Identifying the location of structures prior to submergence in 1938 aided in understanding how reservoir flow and hydraulics operate during submergence and re-emergence, and the stress impacting structural stability.

A time series of lake elevation was generated using historic Bureau of Reclamation gage records. Compiling and sorting the monthly elevation data generated a single line chart that plotted water elevation by month from 1935 to 2005. 


\section{$\underline{\text { Chapter Four }}$}

\section{Results}

This chapter introduces data generated from past research on site formation processes, historic background research, lab research and fieldwork sessions conducted in May 2005 and January 2006 to identify those erosional and depositional processes affecting site formation and degradation at St. Thomas. To deduce and identify those processes affecting site formation and stability, this chapter is broken into five sections: reservoir filling and sediment accumulation, water level fluctuation, fieldwork observations, the submerged environment, and variables contributing to erosion.

These sections will describe and identify those processes controlling and regulating site formation processes at St. Thomas. The information and data within these sections acquaint the reader with the re-emergent and submerged environments of St. Thomas, and provide a detailed study of the erosional and depositional processes effecting site stability and formation during episodes of pool-level fluctuation. The final section identifies and describes the erosional processes and mechanisms causing degradational threats to site and structural stability.

\section{Reservoir Filling and Sediment Accumulation}

As Lake Mead began filling in 1935, five intermountain basins became submerged, that are separated by narrow steep-sided canyons the Colorado River had previously cut through mountain ranges (Longwell, 1948). Lake Mead roughly occupies a $160 \mathrm{~km}$ stretch of the Colorado River channel from the mouth of the Grand Canyon to the Hoover Dam, that creates three distinct arms (Figure 3). The Overton Arm, where St. Thomas is situated, extends $60 \mathrm{~km}$ north of Virgin Basin in the remnant Virgin River Valley, 
Cenozoic rocks from the Muddy Creek Formation underlie the landscape (Figure 8). Slopes along margins of this formation consist predominantly of gentle gradients constructed from submerged alluvial fans or moderately consolidated Cenozoic sedimentary deposits of sand, silt and clay (Longwell, 1948).

Approximately 95 percent of the water recharging Lake Mead is derived from spring thaw originating from snow accumulation in the Rocky Mountains, and the headwaters of the Colorado River. Two additional perennial streams, Muddy and Virgin rivers, are located in the northern apex of the Overton Arm and contribute approximately 2 to 3 percent of the water in Lake Mead. The Virgin River contributes the majority of Lake Mead's water, roughly 1.5 to 2 percent depending on climatic conditions (Longwell, 1948).

Sediment accumulation within Lake Mead has occurred since impoundment of the Colorado River in 1935 though; accumulation in the lake has not been uniform. Surveys conducted during 1999 to 2001 by the Woods Hole Division of the U.S. Geological Survey, revealed that the largest sediment accumulations occurs in the deepest parts of the reservoir and cover the floors of the drowned valleys (Twichell et al., 2003). The derivation of accumulated deposits and dispersion mechanisms operating in Lake Mead are not uniform but are varied due to attempts to minimize reservoir sedimentation (Twichell et al., 2003). 


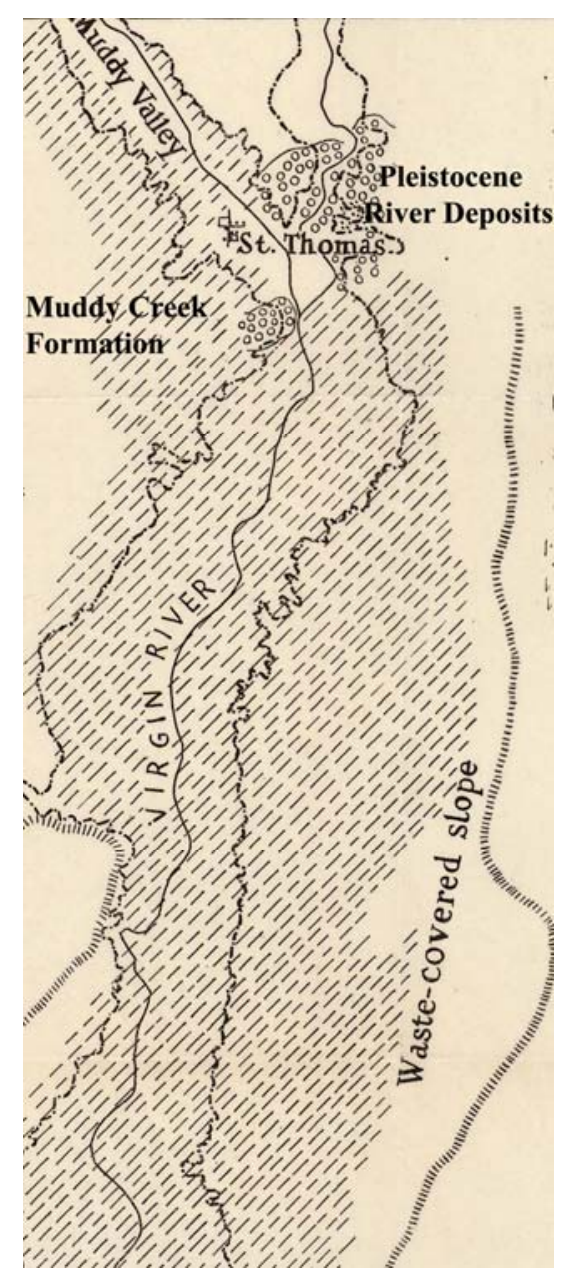

Figure 8: Geology of the Overton Arm. Dashed lines symbolizes Muddy Creek Formation and open dots symbolize Pleistocene river deposits. Modified from: Longwell, 1936.

\section{Pre-1963 Sediment Origin and Transport}

When dams are constructed and reservoirs are formed over rivers that previously transport an extensive sediment volume, then regulation of sedimentation is needed to extend reservoir life. Typically, Colorado River water was turbid prior to dam construction. Early Spanish explorers dubbed it the "colored river” after observing hue variations on the main stem near the junctions of major tributaries (Thomas, 1948). Sediment budget studies conducted by the U.S. Geological Survey indicate that the 
majority of suspended sediment accumulating within Lake Mead prior to 1963 was derived from the Colorado Plateaus province in Arizona, Utah and New Mexico (Twichell et al., 2003).

Holocene alluvium comprises floodplains that flank the main stem and tributaries, and forms islands, bars, and shoals within the channel. The reworking of this alluvium is the dominant source of sediment filling Lake Mead (Twichell et al., 2003). Sediment is also derived, to a lesser extent, from overland flow over impermeable bedrock and in steep, erosive tributary stream channels.

Transportation of suspended sediment into Lake Mead prior to 1963 was primarily a result of stream flow regulated by climatic conditions controlling the storage of alluvial sediments. Trimble (1983) recognized that sediment transport within a fluvial system is not a direct input-output system where sediment added to a river follows a direct path to the terminus (Trimble, 1983). Instead, stream flow velocities and the stream's ability to efficiently transport material of particular sizes regulates sediment budgets.

Alluvium in the Colorado River system is characterized as being in one of three modes: in transit, live sediment, or dead storage (Thomas, 1948). These modes can be altered by fluctuations in the stream-flow velocities of a sufficient magnitude to entrain and transport previously live sediments stored in alluvial features. Major sources of alluvium within the Colorado River are San Juan, Little Colorado, and Paria rivers, where torrential precipitation events elevate flow during August, September and October, and transport previously live sediment into the main stem of the Colorado River system (Thomas, 1948). These sediments remain in live storage within the main stem until spring runoff transports these sediments further down the fluvial system. Ninety-five 
percent of sediments enter Lake Mead within this seasonal window. The Virgin River is thought to contribute 2 to 4 percent entering the reservoir, with the Muddy River contributing far less sediment (Thomas, 1948).

\section{Post-1963 Sediment Transport and Origin}

The life expectancy of a reservoir is dependent upon sediment management and the ability to control sediment filling and sustain water storage capacity. Without any sediment management plan, the productive lifespan of Lake Mead based upon projections of the ratio of sediment volume to the water-storage capacity of the reservoir revealed in a 1948 volume study conducted by U.S. Geological Survey was calculated to be 280 years (Gould, 1948).

To regulate and extend the life of Lake Mead, the Bureau of Reclamation, in conjunction with the states involved in the initiation of the Colorado River Compact of 1922, proposed the Colorado River Storage Project (CRSP). The CRSP was created to more efficiently allocate the mean annual $9,251,100,000 \mathrm{~m}^{3}$ of water that flows between the upper and lower basins by constructing a series of dams in the reaches of the upper basin. The function of this system was to also act a sediment regulatory system to extend the lifespan of Lake Mead. Congress founded the CRSP in 1956, allowing the construction of Glen Canyon Dam and creation of Lake Powell to trap suspended sediments before entering Lake Mead.

To date, approximately 60 dams occur in the upper and lower Colorado River drainage basins and due to over-regulation of water sources, which limits stream flow, and massive water consumption from growing urban populations, the river no longer empties into the Sea of Cortez. Damming is the single greatest hydrological interference by 
humans. Dams influence flow duration and magnitude at all time-scales, and in turn significantly alter the Colorado River's below-dam sediment budget and ability to efficiently transport sediment (Petts, 2005). Damming the Colorado River has transformed a natural open system to a regulated open system dependent on humans to initiate and control flow velocities

Eleven dams are on the Muddy River and six on the Virgin River (National Inventory of Dams, 2005). These dams are not of the same order of magnitude as the Hoover Dam (table 1), but still alter stream hydraulics, stream stability and sediment transport. Dams modify the processes controlling sediment dispersion in the Overton Arm of Lake Mead and sedimentation at St. Thomas.

\begin{tabular}{|c|c|c|c|c|}
\hline Dam & River & $\begin{array}{l}\text { Dam Height } \\
\text { (meters) }\end{array}$ & $\begin{array}{c}\text { Reservoir } \\
\text { Capacity } \\
\text { (cubic feet) }\end{array}$ & Dam Size \\
\hline Glen Canyon & Colorado & 216.4 & 25070481000.0 & Very Large \\
\hline Hoover Dam & Colorado & 222.5 & 36702197400.0 & Very Large \\
\hline Macdonald Lake & Virgin & 4.0 & 123348.0 & Small \\
\hline Quail Creek Div. & Virgin & 22.2 & 363877.0 & Medium \\
\hline Quail Creek South & Virgin & 24.4 & 56740080.0 & Large \\
\hline Rock Springs & Virgin & 9.1 & 616740.0 & Medium \\
\hline Dufurrena Pond & Virgin & 2.4 & 283700.0 & Small \\
\hline Windmill Wash & Virgin & 19.5 & 826432.0 & Medium \\
\hline Bowman Dam & Muddy & 15.8 & 5007929.0 & Medium \\
\hline Mill 1 Pond A & Muddy & 12.5 & 74009.0 & Small \\
\hline Mill 2 Pond D & Muddy & 10.4 & 30837.0 & Small \\
\hline Mill 2 Pond E & Muddy & 4.9 & 246696.0 & Small \\
\hline Mill 2 Pond B & Muddy & 6.1 & 74009.0 & Small \\
\hline Mill 2 Pond C & Muddy & 5.2 & 98678.0 & Small \\
\hline Mill 1 Pond B & Muddy & 13.7 & 18502.0 & Small \\
\hline Honeybee Dam & Muddy & 3.1 & 123348.0 & Small \\
\hline RGS MesaDredge & Muddy & 9.0 & 62167.0 & Small \\
\hline RGS Mesa Ponds & Muddy & 12.2 & 679154.0 & Medium \\
\hline
\end{tabular}

Table 1: List of dams located on the Muddy and Virgin Rivers including tributaries; Hoover and Glen Canyon dams are included for comparison. Dam size is assigned according to Graf's (2005) size definitions of American dams. Dam data were generated from the U.S. Army Corps of Engineers National Inventory of Dams (2005). 


\section{Sediment Transport within Lake Mead}

Suspended sediments derived from Colorado, Virgin, and Muddy rivers and tributary streams, and entering Lake Mead (Figure 9) depend on reservoir hydraulics for dispersion. Density currents operate as a gravity flow of fluid through, under, or over a fluid of approximately higher or lower density with little mixing occurring between the two fluids (Figure 9) (Howard, 1948). Density currents derived from the Colorado River are responsible for transporting sediments that enter the reservoir in eastern Pierce basin and extend throughout the entire reservoir. Density currents flowing through

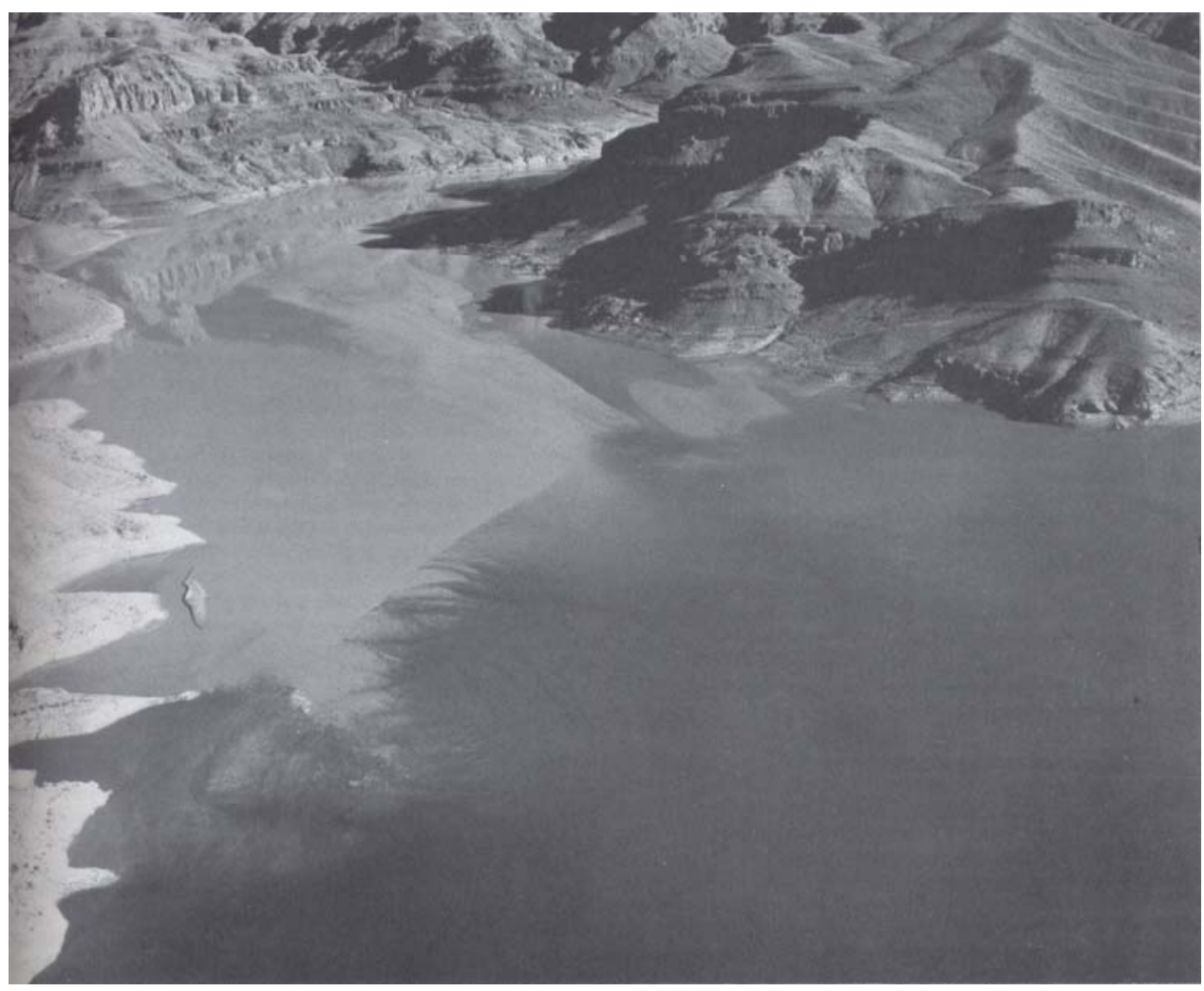

Figure 9: Convergence of Colorado River and Lake Mead in Pierce Basin. Note sharp contrast between relatively clear lake water and turbid river water that rushes down to the lake bottom; this illustrates how density currents operate. Photo source: Howard, 1948. 
Lake Mead is influenced by suspended sediment concentration, dissolved load and water temperature entering the reservoir from the Colorado River and other tributaries (Howard, 1948). These underflow currents climatically and seasonally control the transport status of sediments in the Colorado River. Typically, denser water entering the reservoir plunges to the submerged channel's thalweg, and then flows along the submerged channel dispersing sediment as flow velocity dissipates (Morris and Fan, 1998).

Sediment distribution associated with density currents show outward fining, in which larger sediments (coarse sands) are deposited on a lacustrine delta or at the confluence of river and reservoir waters. The remaining medium and fines (sand, silt and clay) travel longer distances until settling occurs. Analysis conducted by Howard (1948), prior to the construction of Glenn Canyon Dam, indicated that the size of transported particles varies seasonally. During typically low discharges between November and March, sand particles larger than 62 microns compose less than ten percent of the suspended load, whereas clay particles smaller than 4 microns make up over half of the total. These relationships are reversed during spring thaws from April to January when Colorado River flow volume is greatest, and carries greater than 50 percent sand and less than 10 percent clay. Coarse sands greater than 500 microns become entrained by spring flows, but typical annual suspended load outside of large discharge events comprise less than 30 percent sand of 62 microns (Howard, 1948). Since construction of Glenn Canyon Dam, a decrease in sedimentation has occurred, along with a degree of sediment fining due to upstream sediment trapping from Lake Powell. 


\section{Additional Inputs Affecting Sedimentation at St. Thomas}

Deciphering the origin of deposits at St. Thomas is complicated by the site's location at the confluence of the Muddy and Virgin rivers. These perennial streams are fed by two different sources. Whereby springs sustain flow in the Muddy River and the Virgin River derives most of its flow from high plateaus and the Pine Valley Mountains in southwestern Utah. The Virgin River contributes more sediment than the Muddy River, but the exact percentage is dependent upon seasonal and climatic variations that regulate flow velocities (Longwell, 1948).

Little research is available density currents associated with Virgin River transport sediments within the Overton Arm. Surveys conducted by U.S. Geological Survey in 1940 (Gould, 1948) indicate that sediment from the Virgin River extends approximately $28 \mathrm{~km}$ south into Lake Mead, but the extent to which density currents transport sediments further within the remnant channel is debatable (Gould, 1948). Evidence from these U.S. Geological Surveys indicates clay, silt and sand have traveled approximately 18 km upstream from the former junction of the Virgin and Colorado rivers at the Lower Narrows (Gould, 1948). Visual surveys conducted by the Bureau of Reclamation during 1940 to 1948 indicate high suspended loads occur in seasonal conjunction with increased Colorado River discharge events during April. In January they disappear and return to lower density loads comprised of medium and fine grained of 4 to 62 microns (Howard, 1948).

Questions arise over the source or sources of sediments deposited at St. Thomas. St. Thomas's location west of the mouth of the Virgin delta has left open-ended questions concerning sediment deposition. Bottom samples taken in 1948 indicate that a $60 \mathrm{~cm}$ 
layer of silt and clay accumulated on top of the original sandy channel bottom at the toe of the delta near the Lower Narrows of Overton Arm. Density currents associated with the Virgin River are assumed to be the mechanism depositing these sediments, but the extent to which density currents from either the Virgin or Muddy rivers contribute to sediment accumulation at St. Thomas is uncertain.

\section{Observations of Sediment Thickness, Dispersion and Accumulation Rate}

Sidescan sonar and high-resolution seismic data acquired during the 2001 Woods Hole (Twichell et al., 2003) survey of the Virgin Basin and Overton Arm of Lake Mead allowed mapping of the post-impoundment sediments to determine the thickness of accumulation within each basin (figure 10). Sediment accumulation is sparse in the Overton Arm and in the area surrounding St. Thomas, but deposition is apparent in the remnant Muddy channel. 


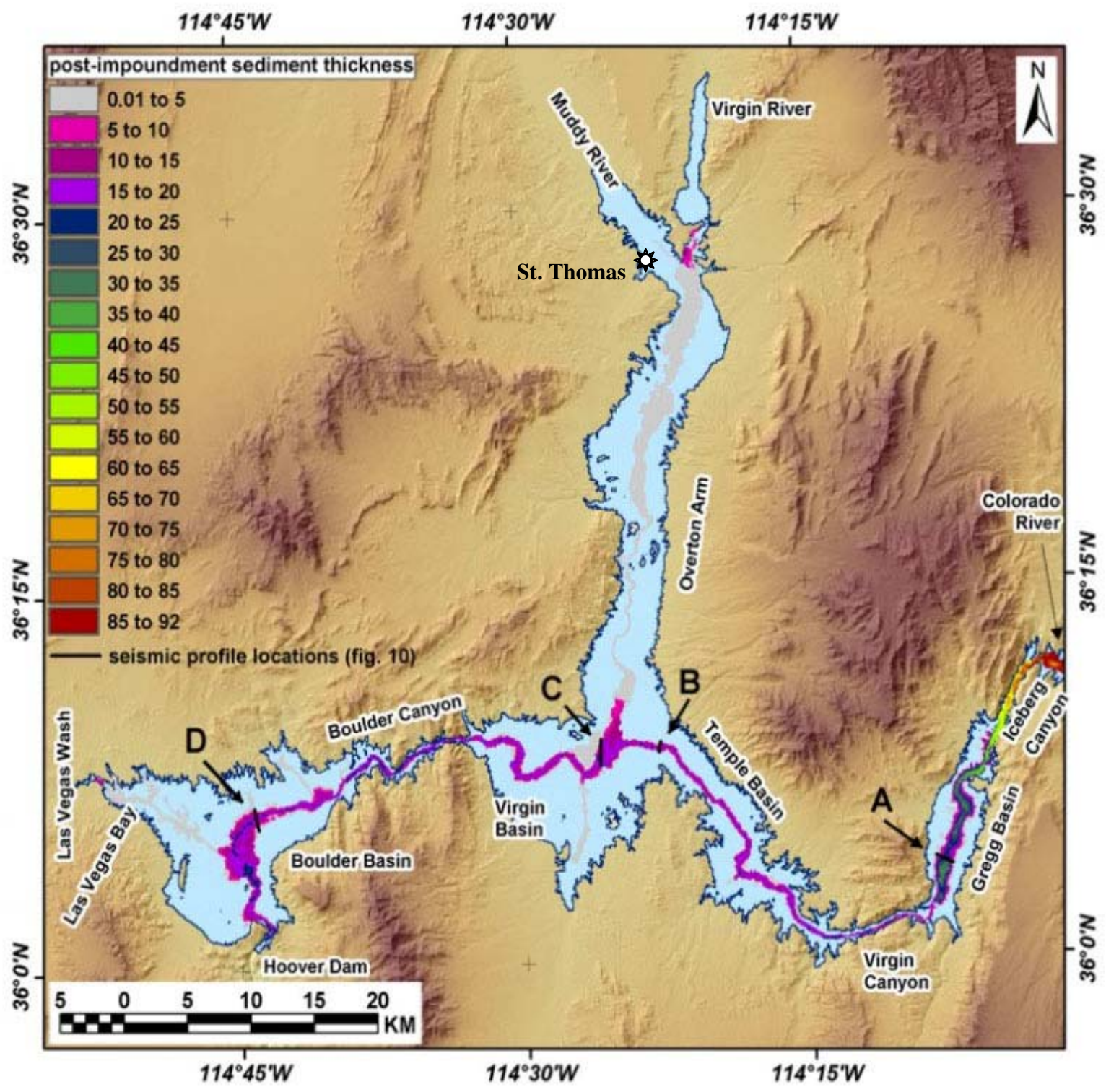

Figure 10: Map of the thickness of post-impoundment sediment in Lake Mead. Light blue indicates lake area. These sediments have accumulated since completion of the Hoover Dam in 1935. Modified from: Twichell et al., 2003.

Side-scan imagery does reveal other areas of sediment accumulation within St.

Thomas (Figure 11). This image depicts several remaining roads and foundations and the largest foundation located in the southeastern corner is the St. Thomas schoolhouse. In contrast to other foundations, which give a high acoustic backscatter and appear white, the interior of the schoolhouse foundation is a distinct dark grey similar to the reflectance 
from the post-depositional sediments in the former bed of the Muddy River, and giving a clue that walled structures such as the schoolhouse are possible sediment traps.

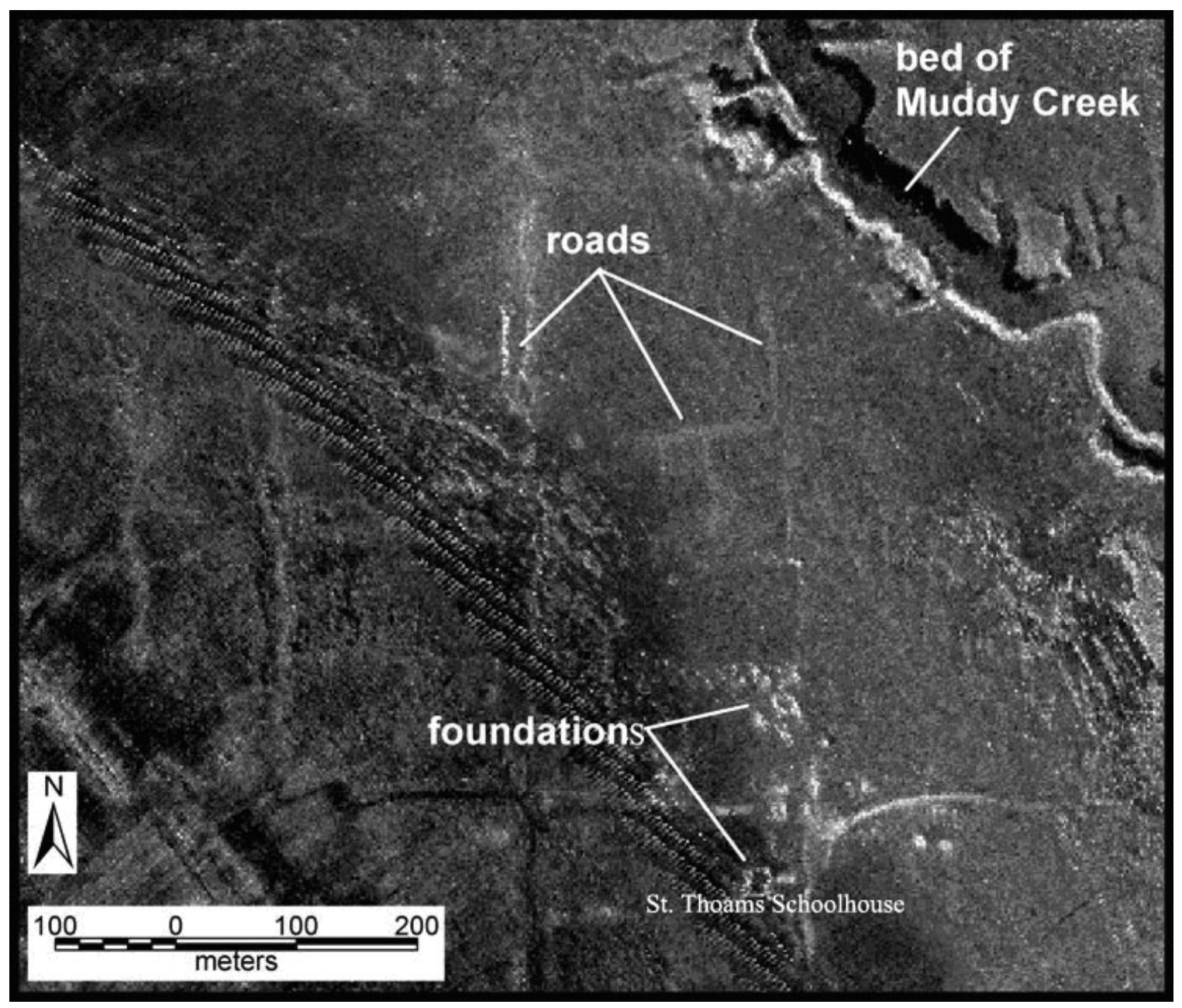

Figure 11: Sidescan-sonar image of the town of St. Thomas, which was submerged shortly after Lake Mead started to fill. Streets trend north-south and east-west and some of the high-reflectance targets are foundations. Modified from: Twichell et al., 2003.

The rates of sediment accumulation are uncertain and are not a primary objective of this project. However, sediment accumulation research conducted by U.S. Geological Survey (Covay and Beck, 2001) offers a general overview of accumulation rates in the Overton Arm. St. Thomas's depositional history is complicated for reservoir down-draw caused by environmental and societal influences upon Colorado River causes pool-level 
shallowing, and the placement of dams on Virgin and Muddy rivers upstream of the reservoir influences sediment dispersion processes.

Surveys performed by the U.S. Geological Survey (Covay and Beck, 2001) in 1998 attempted to discern sediment deposition rates throughout Lake Mead utilizing cesium$137\left({ }^{137} \mathrm{Cs}\right)$, an anthropogenic by-product of atmospheric nuclear testing, as a stratagraphic marker to calculate sediment accumulation during three different periods: from the initial impoundment (1935 to1937) to the appearance of ${ }^{137} \mathrm{Cs}$ in the atmosphere in 1952; from 1952 to the maximum concentration of ${ }^{137} \mathrm{Cs}$ in the atmosphere in 1964; and from 1964 to the 1998 data collection date (Covay and Beck, 2001). Deposition rates for the first period varied throughout the reservoir due to variability in each site's date of submergence. However, cores taken at Stewart Point, roughly $14 \mathrm{~km}$ south of St. Thomas, showed annual sediment deposition rates as $0.80 \mathrm{~g} / \mathrm{cm}^{2} / \mathrm{yr}$ (Covay and Beck, 2001). Exact rates of accumulation could not be calculated for the second and third periods at Stewart Point due to uncertainty in locating the $1964{ }^{137}$ Cs peak (Covay and Beck, 2001). Deposition in other areas of the lake varied, based on distance from the confluence of the Colorado River into Lake Mead at Pierce Basin indicate a significant decrease in accumulation in cores taken from the submerged Colorado River channel during the third period when Glen Canyon Dam became operational.

\section{Water Level Fluctuation}

As discussed thus far, determining sediment deposition origins and rates is complicated by reservoir hydraulics and human and environmental influences on the fluvial systems effecting St.Thomas. To date, post-depositional sediments at St. Thomas cannot be attributed to density currents of the Colorado, Virgin, or Muddy rivers. 
Erosional processes during reservoir down-draw complicate identifying the mechanisms responsible for depositing these sediments, by removing sediments from their original locations and destroying stratagraphic markers in depositional sequences. Three documented re-emergence periods occurred in 1945, 1955 and 1965, prior to the most recent 2003 emergence (Daraon, S., oral communication, 2006). However, analysis of historic Lake Mead elevation records, in combination with a 1932 topographic map benchmark elevation of $1150 \mathrm{ft}$ ( $350 \mathrm{~m}$ ) (figure 12) at St. Thomas, reveals additional reemergence events occurred in 1946, 1947, 1949, 1951, 1952, 1954 and 1964 as a result of reservoir down-draw (Figure 13). A time series was created to reveal a sequence of emergent episodes occurring from 1935 to 2005 (Figure 13).

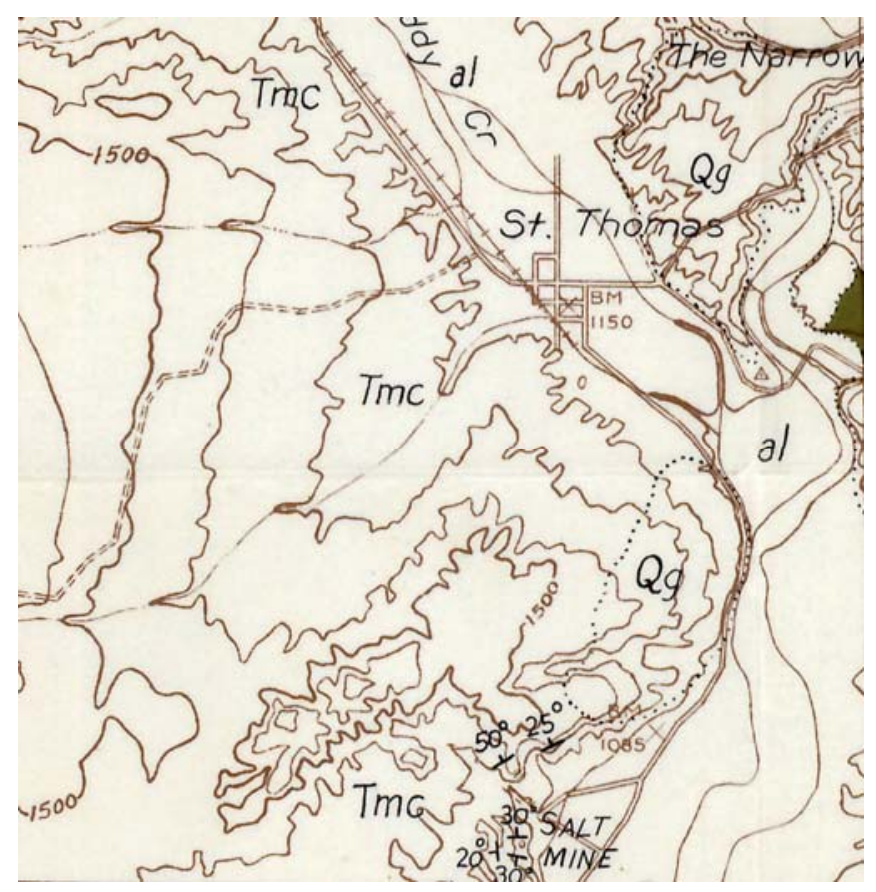

Figure 12: Bench mark on 1932 topographic map indicates surface elevation at St.Thomas as $1150 \mathrm{ft}$ ( 350 m). Map from: Longwell,1932.

The stage recovery rate for each reemergence phase varies and episodes occurring from 1945 to 1947 and 1949 to 1951 returned to pool levels during the next spring thaw 
(Figure 13). Episodes from 1954 to 1957 and 1964 to 1970 remain continuously reemerged until the reservoir regained its pool level in 1957 and 1970 (Figure 13). In addition to revealing re-emergence episodes, respectively figure 13 also illustrates historic water regulation on the Colorado River. Prior to 1969 annual lake elevations fluctuated dramatically. However since 1969 water levels have remained somewhat static or suggest gradual increases or decreases occurring. This change in fluctuation is attributed to upstream regulation by Glen Canyon Dam that became operational in 1969. However, since 2000 the waters of Lake Mead have receded as a result of increased water usage and decreased snow accumulations. Increased water regulation is not a solution to this problem. Once again in 2003 St. Thomas's structures re-emerged and it is uncertain if or when lake levels will rise to re-submerge St. Thomas. 


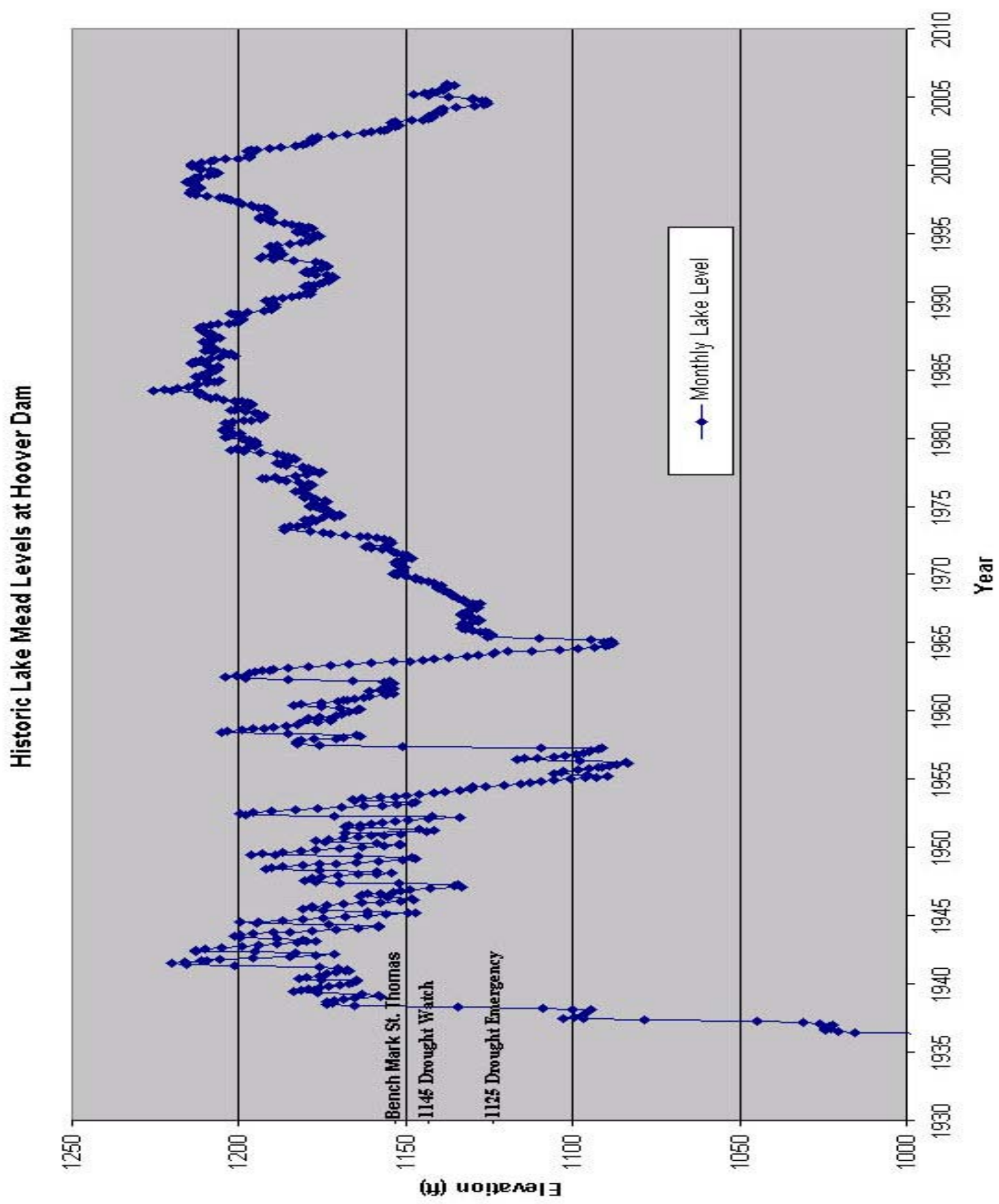

Figure 13: Historic water level fluctuations at Lake Mead. 
Field Observations- May $6^{\text {th }}$ to $12^{\text {th }} 2005$

The first session of field research was conducted to develop a preliminary scope of work, determine the feasibility of the project and apply for the necessary permits. Meetings were arranged with the cultural resources team of Lake Mead NRA and surveys were conducted at St. Thomas to determine the building materials utilized during construction, perform condition assessments on the remaining features and conduct preliminary visual investigations to determine variables contributing to erosion.

\section{Composition and Condition of Remaining Structures}

The building structure composition is integral to determine resistance to erosion. Five building materials were utilized at St. Thomas: adobe, wood, brick, sandstone and coarse gravel-aggregate concrete with a thin outer layer of fine textured concrete (Jensen, E. oral communication, January, 2006). Adobe was primarily used during the early stages of the settlement. No adobe or intact wood structures persist at St.Thomas. Brick and stone are the least common materials remaining for those buildings constructed with brick, such as the Gentry Hotel (Figure 14) or St. Thomas Schoolhouse (Figure 15), were disassembled and used in the construction of buildings in Overton, Nevada (Jensen, E. oral communication, January, 2006). Sandstone was used as a secondary building material in

the construction of the Gentry Store (Figure 16) (Jensen, E. oral communication, January, 2006). Neither the Gentry Store, nor the Hotel, retains any significant structural walls. Only footings or remnants of foundations remain (Figures 17 and 18). 


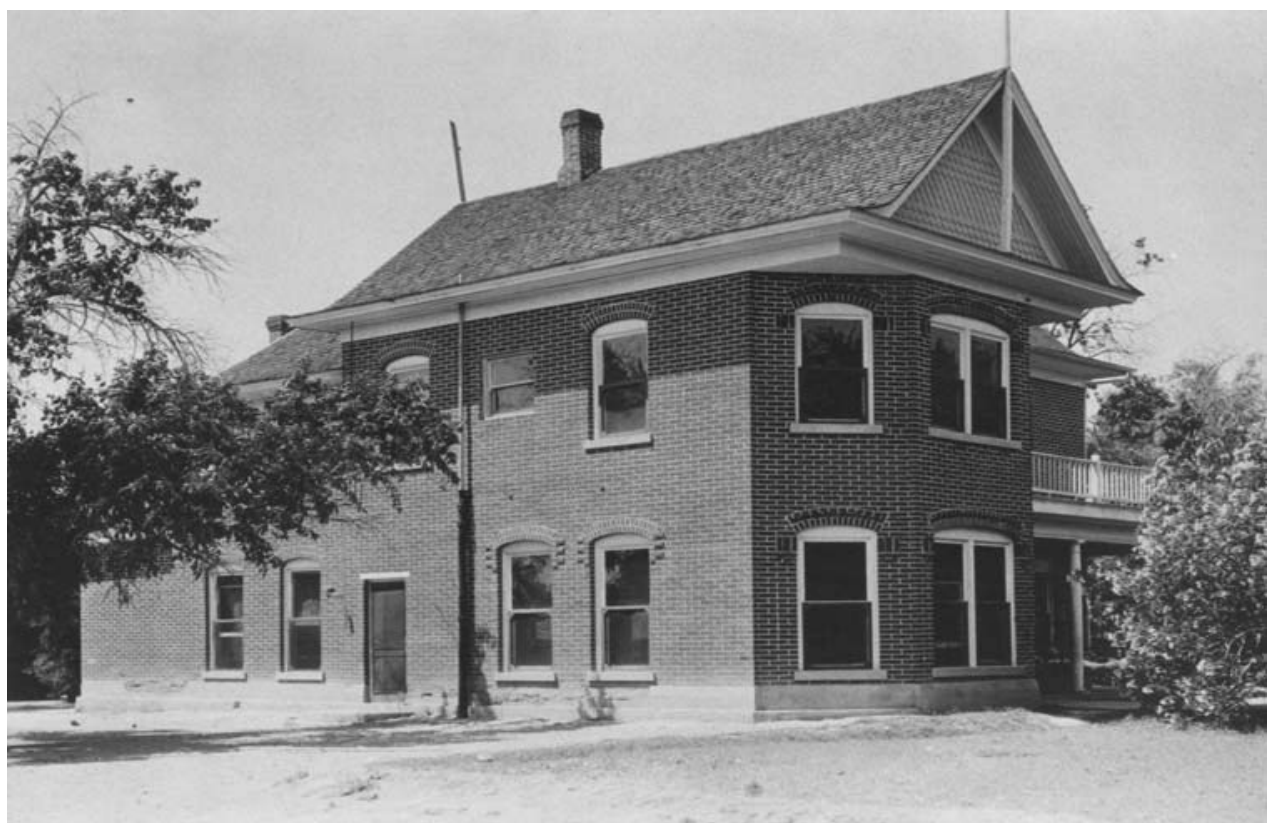

Figure 14: Gentry Hotel, May $13^{\text {th }} 1934$. Photo source: University of Las Vegas Lied Special Collections Library.

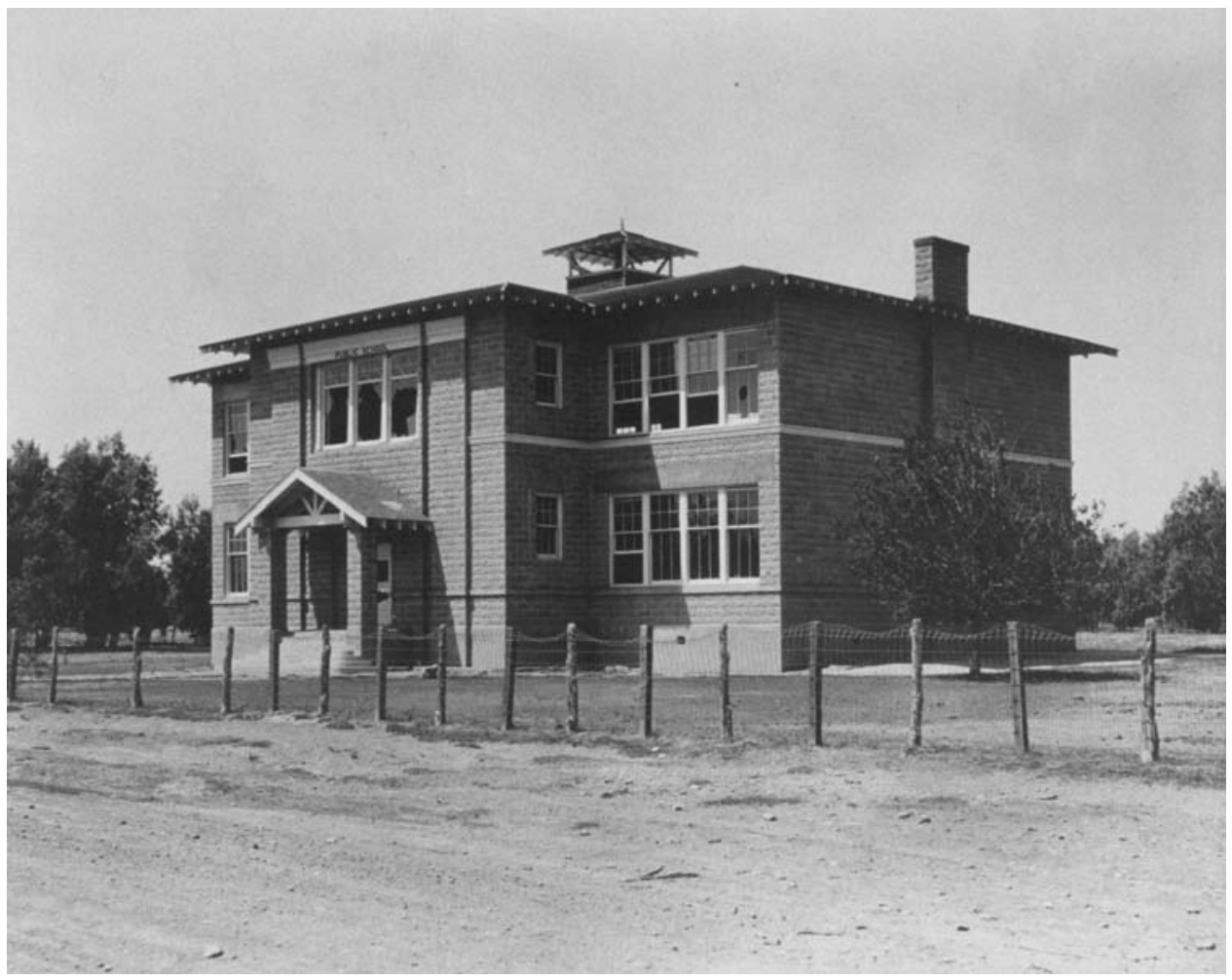

Figure 15: St. Thomas Schoolhouse, May $13^{\text {th }} 1934$. Photo source: University of Las Vegas Lied Special Collections Library. 


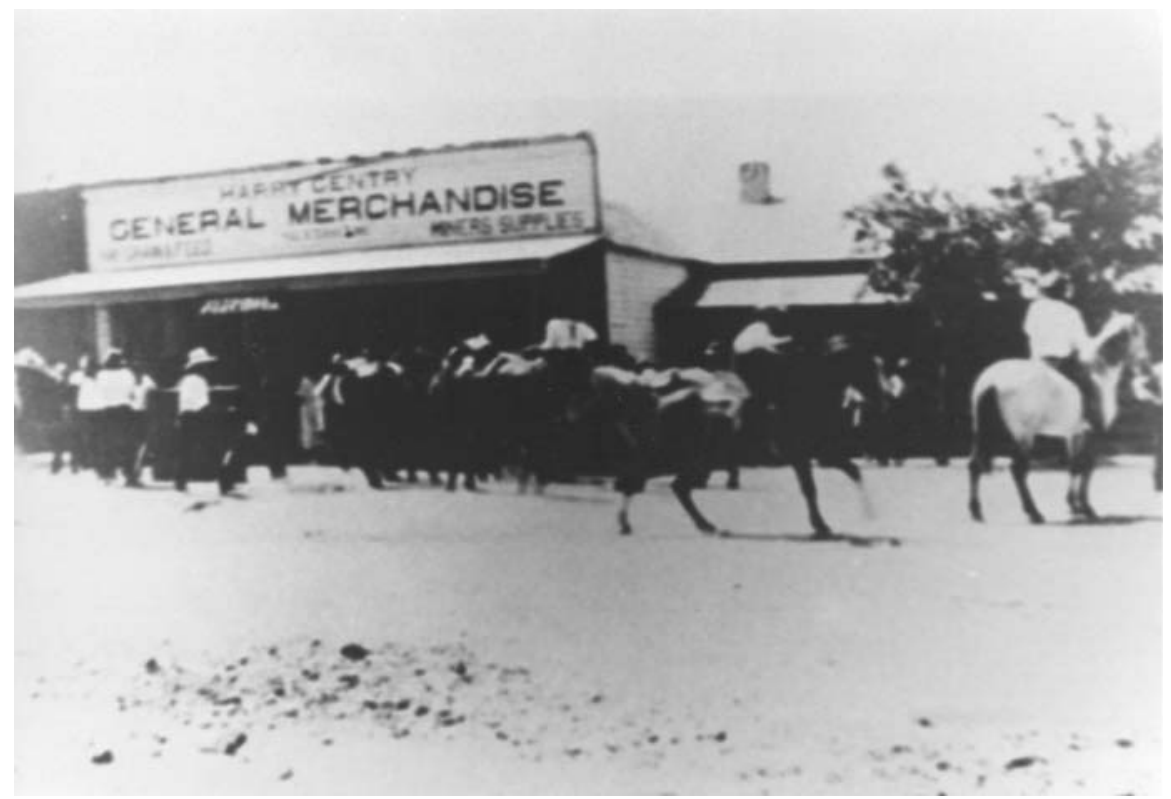

Figure 16: Gentry Store, circa 1900. Photo source: University of Las Vegas Lied Special Collections Library

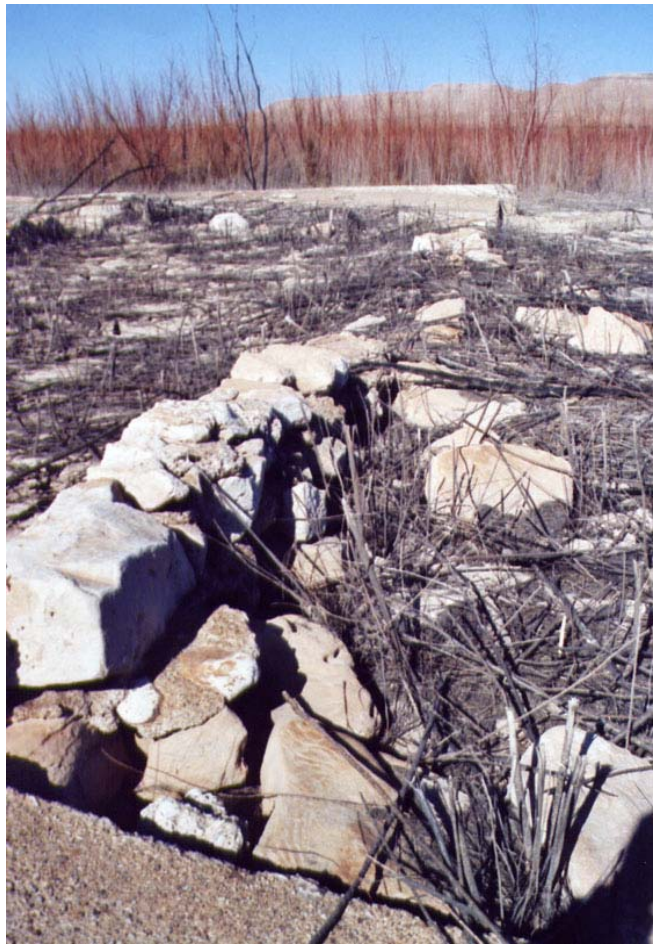

Figure 17: Gentry Store. Photo taken January 2006. 


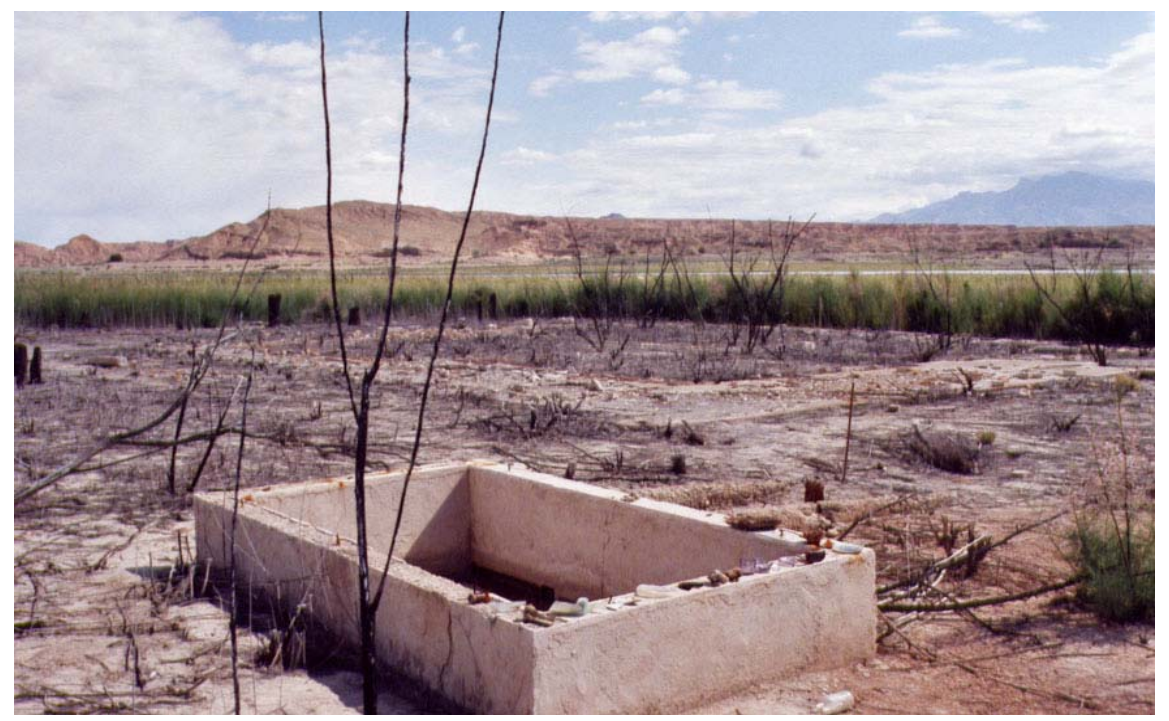

Figure 18: Gentry Hotel. Photo taken May 2005.

Concrete is the primary building material used in structures with intact walls. These structures were constructed by hand mixing concrete, and then pouring the mixture into molds with reinforced rebar (Jensen, E. oral communication, January, 2006). Structures composed of fine textured concrete, such as the blacksmith shop (Figure 19) or schoolhouse (Figure 15), have retained structural integrity and resisted erosion better than structures comprised of coarse gravel concrete with an outer layer of fine textured concrete. Commonly, the outer layer of concrete is crumbling and spalling from walls (Figure 20). The variables contributing to the decay of these structures is a focus of this research. 


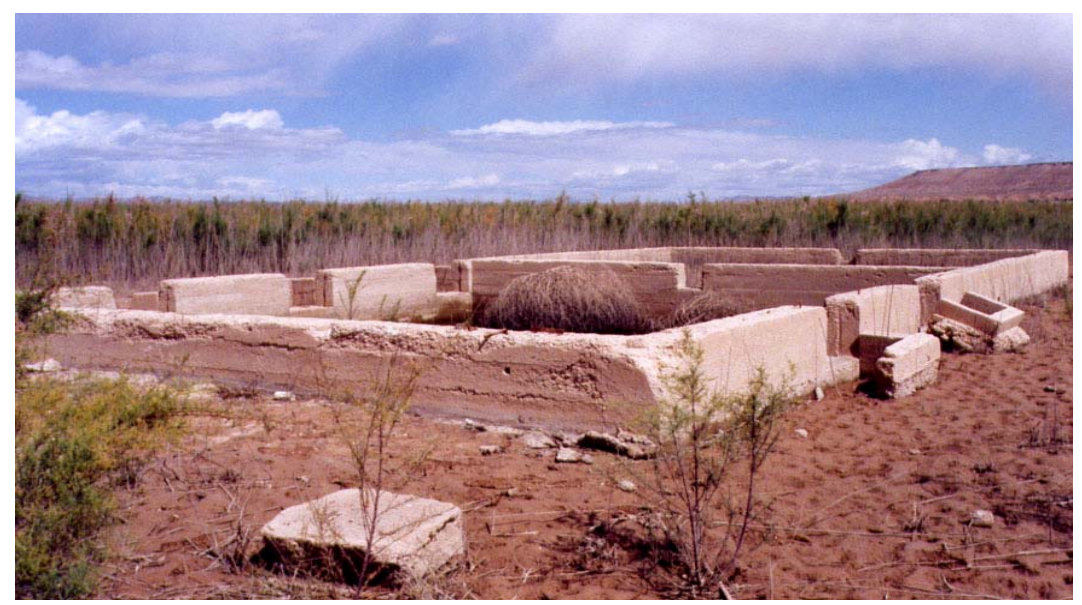

Figure 19: Blacksmith shop. Photo taken May 2005.

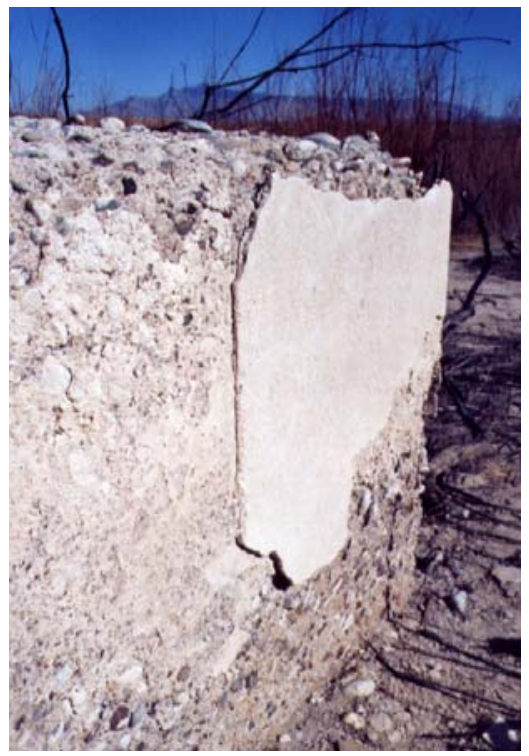

Figure 20: Spalling of concrete on the Gentry House. Photo taken January 2006.

\section{Observed Structural Decay}

Isolating the variables contributing to the decay of the remaining structures at St.

Thomas is difficult because variables often combine and actively work together to produce similar effects. Figure 20 is a typical example of spalling that occurs on the outer layers of concrete on structures. Spalling occurs when the outer layer of concrete weakens and separates from the structure to which it adhered. The typical cause of 
spalling at St. Thomas is freeze thaw action, the weakening of the outer layer due to continuous and extreme environmental changes or prolonged forces such as wind or wave action that degrade the resistance strength of the material. The second field session was devoted to deciphering additional erosional mechanisms and processes operating on site.

\section{Field Observations- January $17^{\text {th }}$ to $24^{\text {th }} 2006$}

Visual inspection of the St. Thomas area indicated that the site must be examined as a large and small scale archaeological resource to adequately represent and identify the changes occurring at St. Thomas since submersion (Lenihan et al., 1981). Examining the settlement within this perspective allows a broad overview of the processes compromising stability.

The objective of the second field session was to determine the primary variables contributing to erosion and structural instability, and deduce possible provenance and processes contributing to deposition. Two $1 \mathrm{~m}$ by $1 \mathrm{~m}$ test units were excavated. One unit was placed within the blacksmith shop and the second within the St.Thomas Schoolhouse. In addition, soil probes were placed at 11 areas of the site to determine the depth of post 1935 sediments. The remaining field time was used to conduct condition assessments on remnants of the structures, visually inspect the site to deduce erosional processes at work affecting site formation and survey the Muddy River.

The placement of $1 \mathrm{~m}$ by $1 \mathrm{~m}$ test units was limited to intact walled structures with the minimal presence of Tamarix ramosissima and no standing water. The first test unit was excavated within the blacksmith shop (Figure 19). Upon excavation, the unit was located $\sim 100$ meters from the shoreline and is in fair condition. The walls are $41 \mathrm{~cm}$ high and the structure is approximately $8 \mathrm{~m}$ by $5 \mathrm{~m}$. 
The blacksmith floor plan shows two rooms with a basement. The test unit was placed in the upper room (Figure 21). The uppermost C stratum consisted of a pink (7.5YR 8/4), silty sand. This horizon contained historic material from early 20th Century occupation: amethyst- clear-, milk-, and brown-glass fragments; ceramics; finishing nails; miscellaneous metal objects; a button and wood splinters. The lower boundary of this stratum was reached at approximately $11 \mathrm{~cm}$ where a distinct color and texture change was identified. Faunal disturbance from Asiatic freshwater clams (Corbicula fluminea) were present throughout the $\mathrm{C}$ stratum.

The stratum below the $\mathrm{C}$ was identified as brown (7.5yr 5/4), silty medium-grained sand. This stratum retained considerable moisture and was sterile of cultural material and Asiatic clams (Corbicula fluminea). Excavating this stratum unearthed the cement footer of a center support structure, a burn stain in the eastern portion of the unit and an oxidized stain in the northern portion of the unit (Figures 22 and 23). The burn could be evidence of the tendency for citizens of St. Thomas to burn their residences at departure, to show their disdain for having been forcibly evicted from their homes and property. A considerable amount of oxidized metal fragments and nails were found throughout the upper C stratum and possibly leached into the lower A stratum, causing the stain. No metal was found in the A stratum. Due to the absence of artifacts, compactness of the soil, and the location of the cement footer, this horizon is thought to constitute the original A horizon of the settlement soil. Excavation continued $5 \mathrm{~cm}$ into the stratum, which was determined to constitute the original settlement soil. 


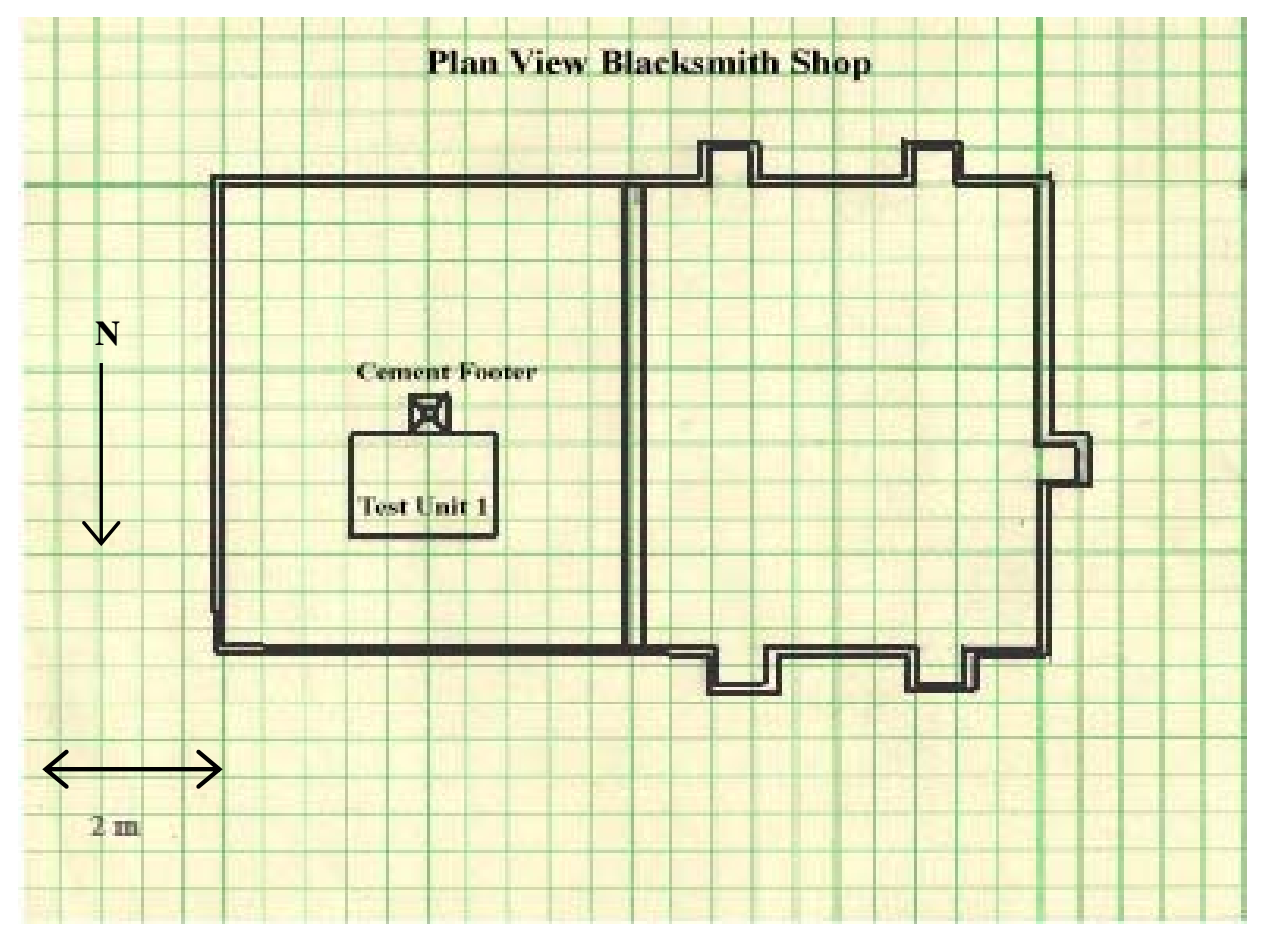

Figure 21: Plan view of the blacksmith shop indicating placement of Test Unit 1.

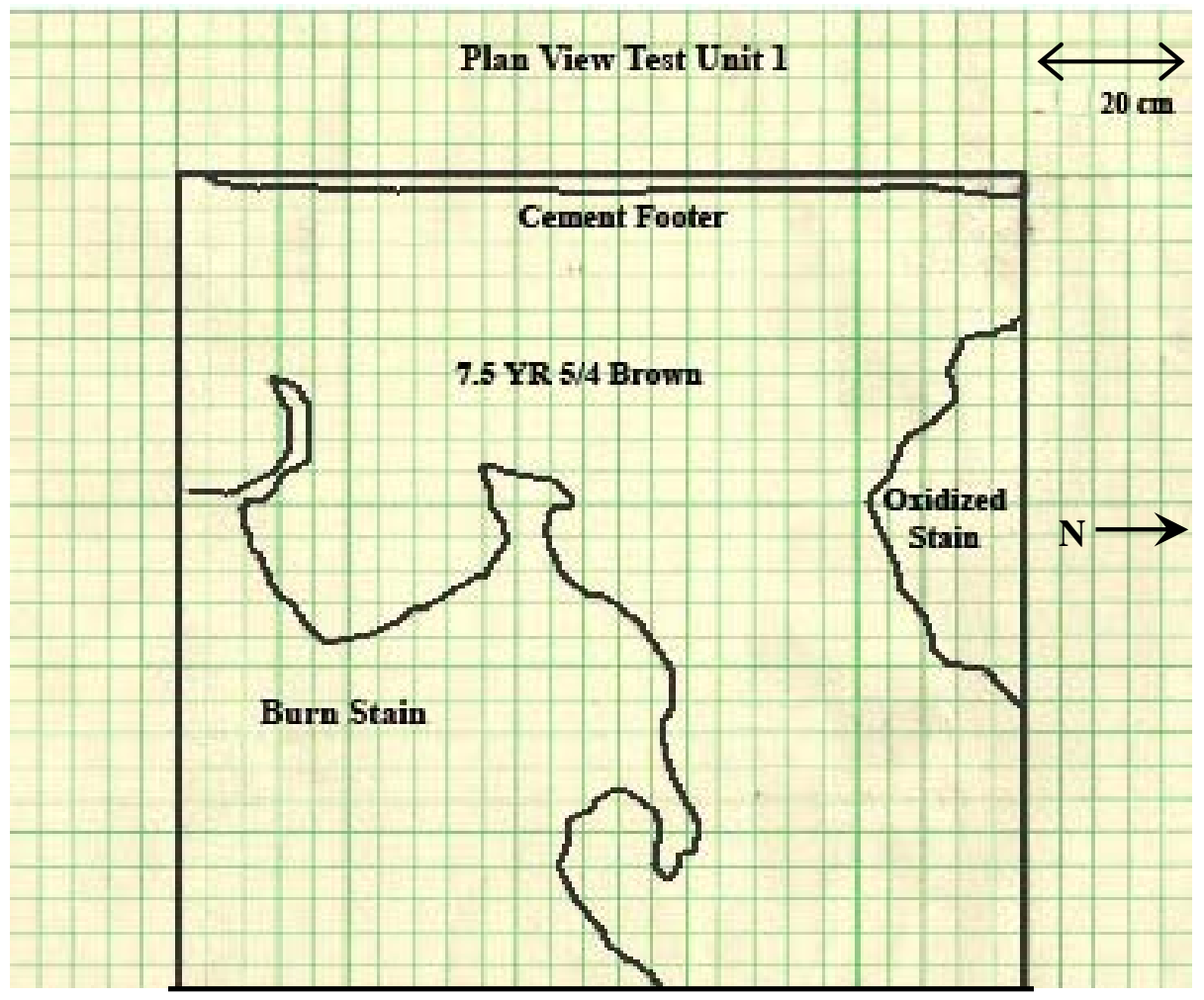

Figure 22: Plan view of Test Unit 1 at terminus of excavation. 


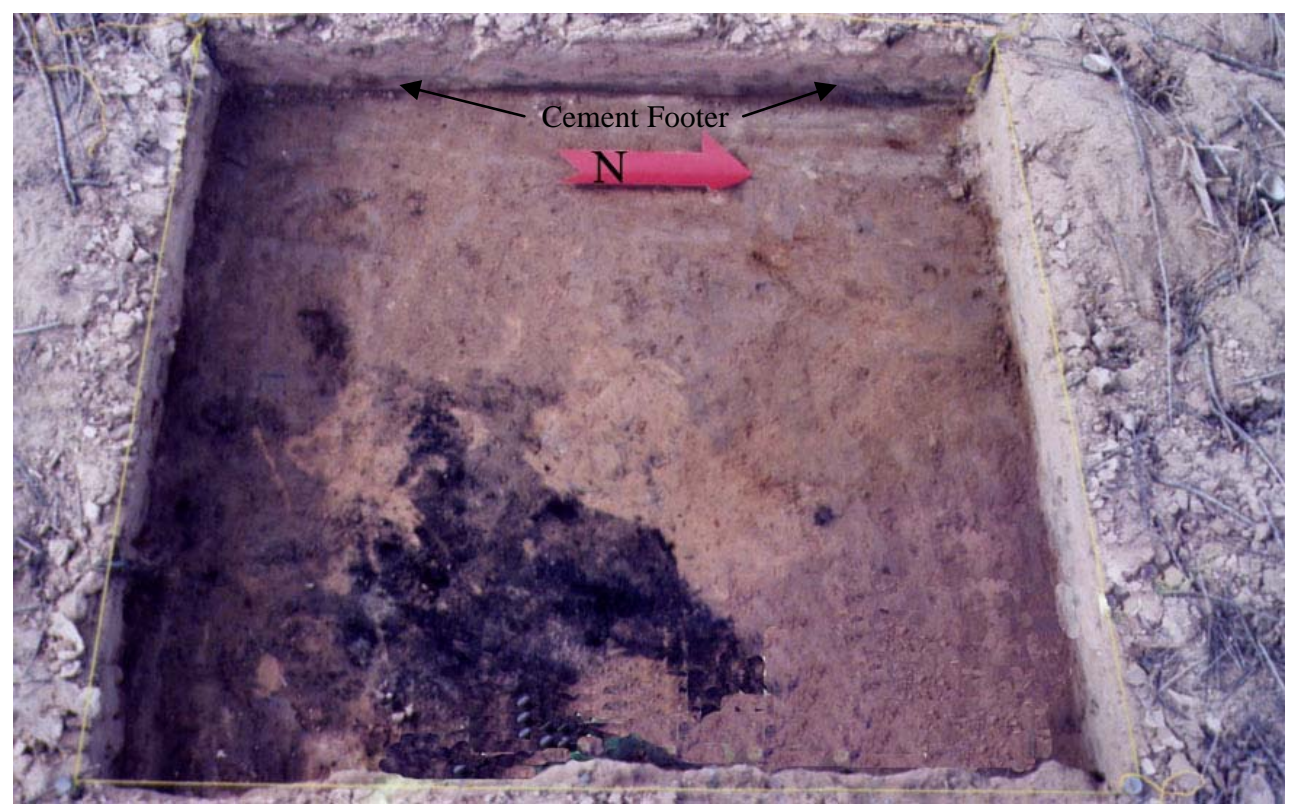

Figure 23: Test unit one terminus of excavation. Note burn stain in lower left, oxidized stain to the right center and cement footer slightly protruding from the west wall. Photo taken January 2006.

The second test unit was placed inside the schoolhouse. This structure's walls are 107 cm high. The areal dimensions of the structure are approximately $25 \mathrm{~m}$ by $13 \mathrm{~m}$.

Placement of this test unit was used to deduce if erosional and depositional activities occured within larger structures. The plan view inspection of the sediments within the interior of the schoolhouse indicates a concave build up of sediments near the exterior east and west walls, shallowing in the center suggests that wind-wave action has caused uneven deposition (Figure 24). 


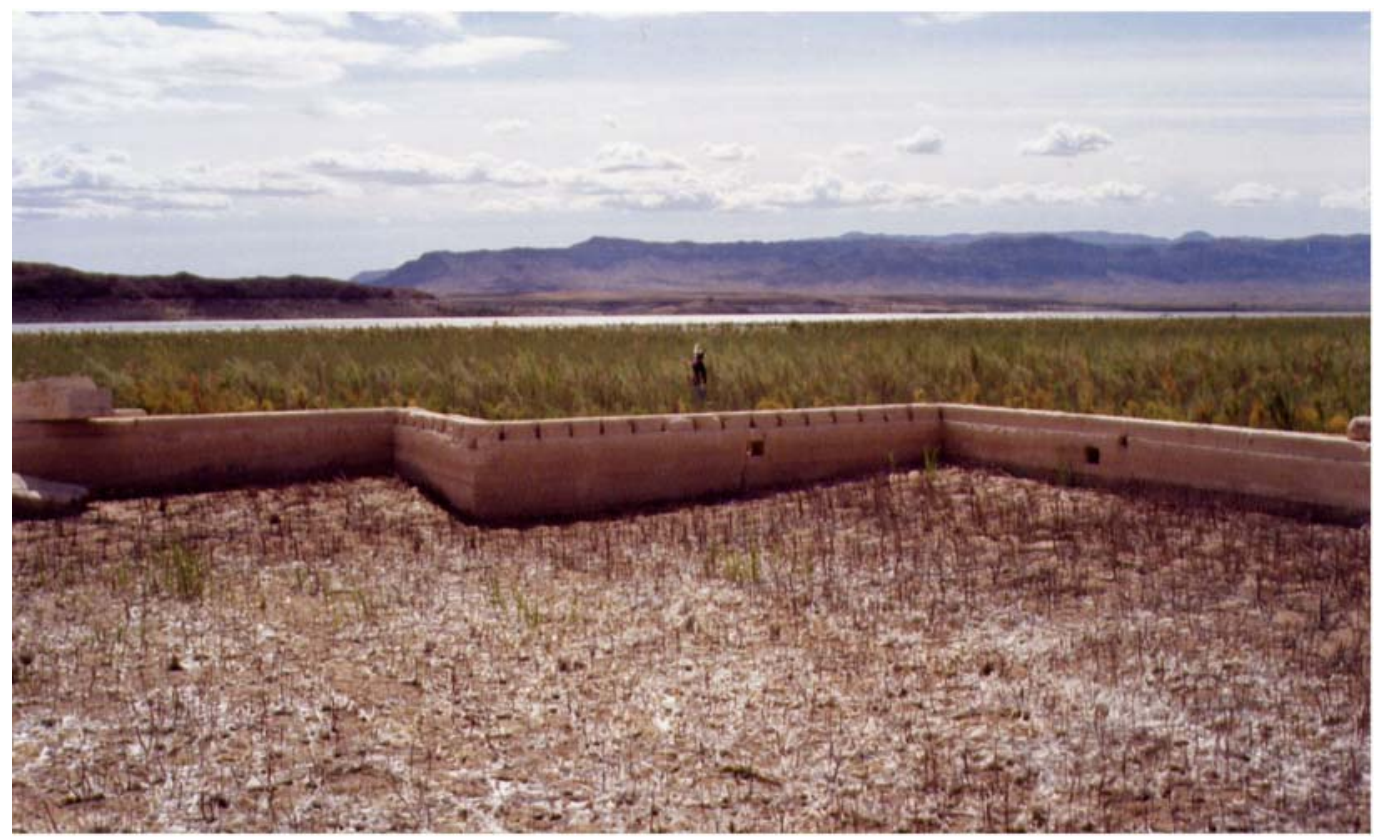

Figure 24: Portion of the foundation of the St. Thomas Schoolhouse, looking southwest toward Lake Mead. Note concave distribution of sediment from the center of the photo to the walls. The person in the foreground marks the standing water boundary. Photo taken May 2005.

The test unit was placed in the center of the schoolhouse structure (Figure 25).

Excavation of the unit revealed a similar depositional sequence to the unit located in the blacksmith shop. Two distinct soil strata that share the same color and textural characteristics as unit one were found in unit two. However, the C stratum in the schoolhouse showed disturbance in the southeastern, northeastern and northwestern corners. An excavation $9 \mathrm{~cm}$ deep into this stratum unearthed remnants of a collapsed structural support with considerable $20^{\text {th }}$ Century cultural material, such as glass, miscellaneous metal, finishing nails and ceramics scattered throughout the stratum. A circa $1980 \mathrm{Hi}-\mathrm{C}$ soda pop can was found $18 \mathrm{~cm}$ deep in the stratum near the southeast corner and possibly was discarded by fishermen during elevated water levels. This artificial fill is light grey (10yr 7/2), with a coarse sandy silt texture. 


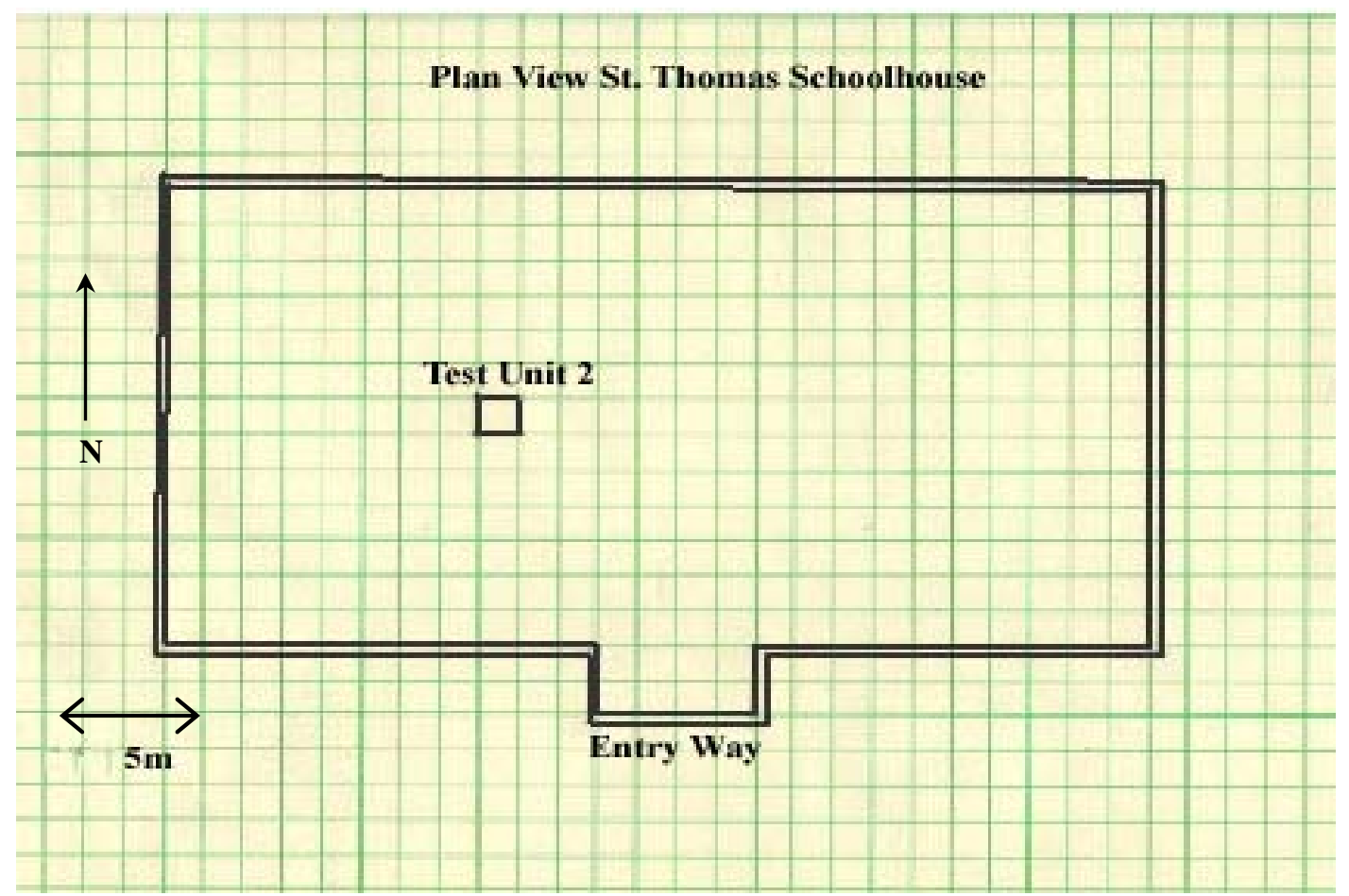

Figure 25: Plan of St. Thomas Schoolhouse indicating approximate location of Test Unit 2.

The A stratum is a brown (7.5yr 5/4), silty medium sand, as found in test unit one. The stratum was reached in the southwest and center portion of unit two. Excavation ceased in the remaining portions of the unit when cement structures and intact timbers were uncovered (Figures 26 and 27). The purpose of this structure is unknown, but its location in the center of the schoolhouse and the presence of timbers suggests a bracing feature used to support a wood floor. 


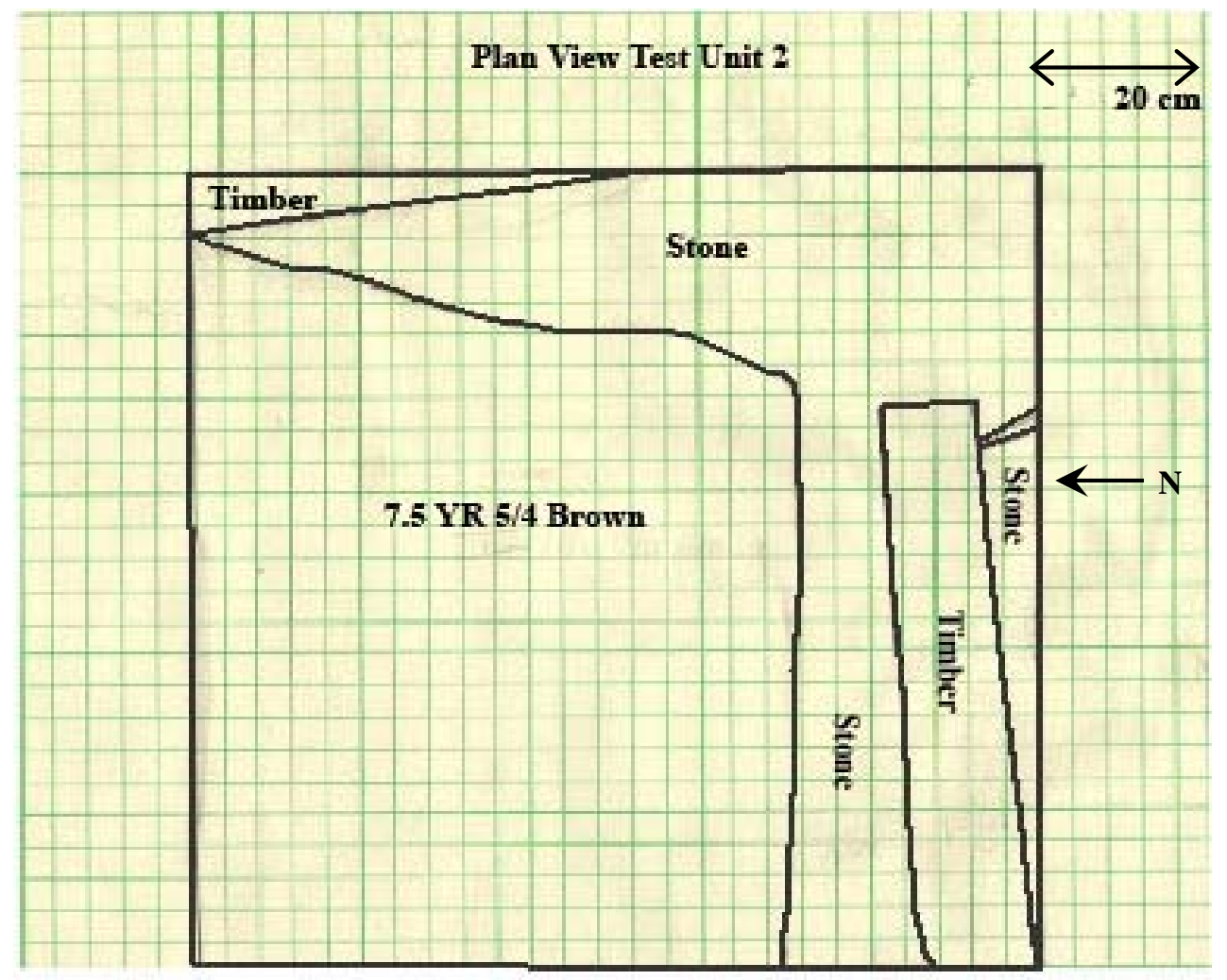

Figure 26: Plan view of Test Unit 2 at terminus of excavation.

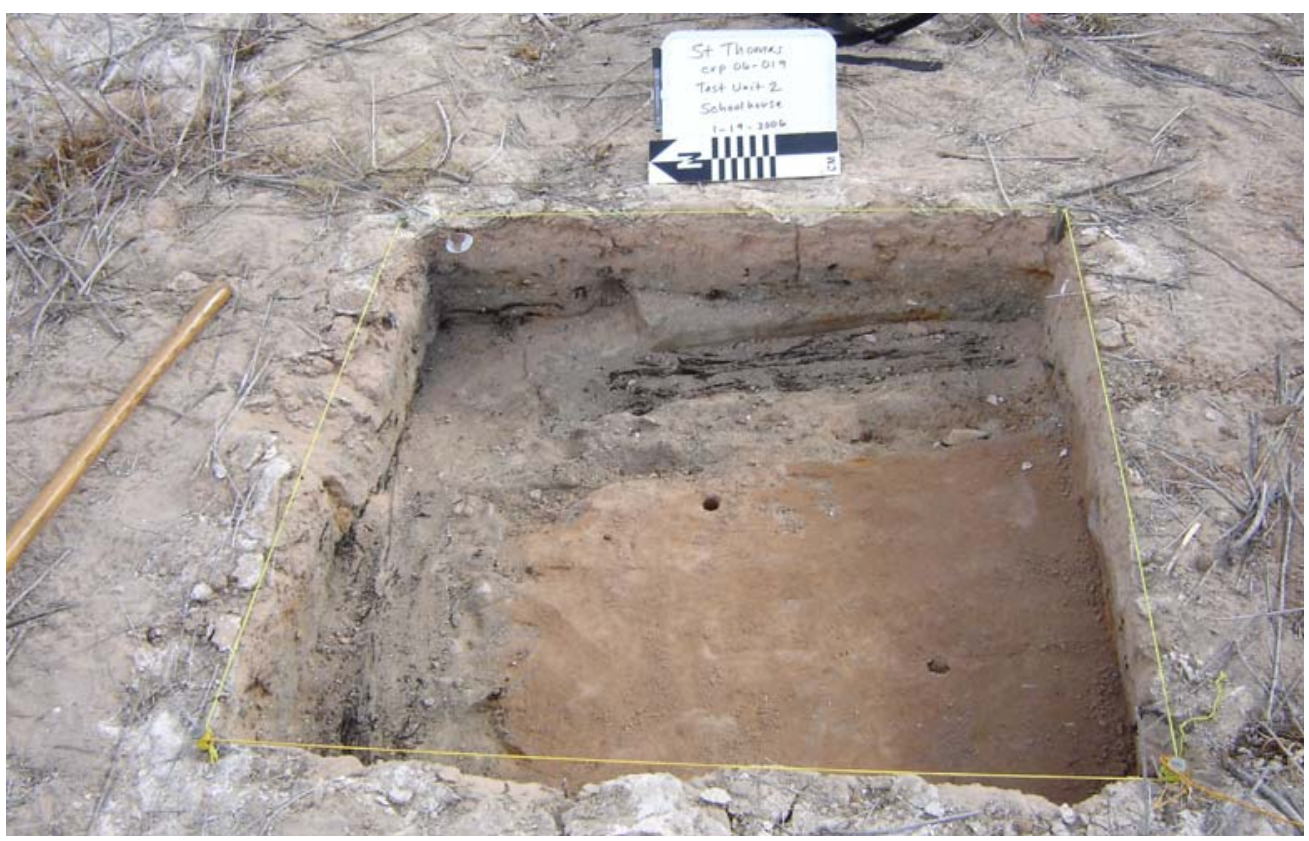

Figure 27: Test unit two at terminus of excavation. Note brown color in southwest portion, and light grey sediments with timbers and concrete structure in the remainder of the unit; the light grey sediments are artificial fill. Photo taken January 2006. 
The survey during the January field session was more productive than the previous session conducted in May for visibility was less obstructed due to the leaf-off status of the tamarisk (Figures 28 and 29). However, as visible in figures 28 and 29, the dense tamarisk made it difficult or impossible to conduct survey or visual inspection of many areas within the study site.

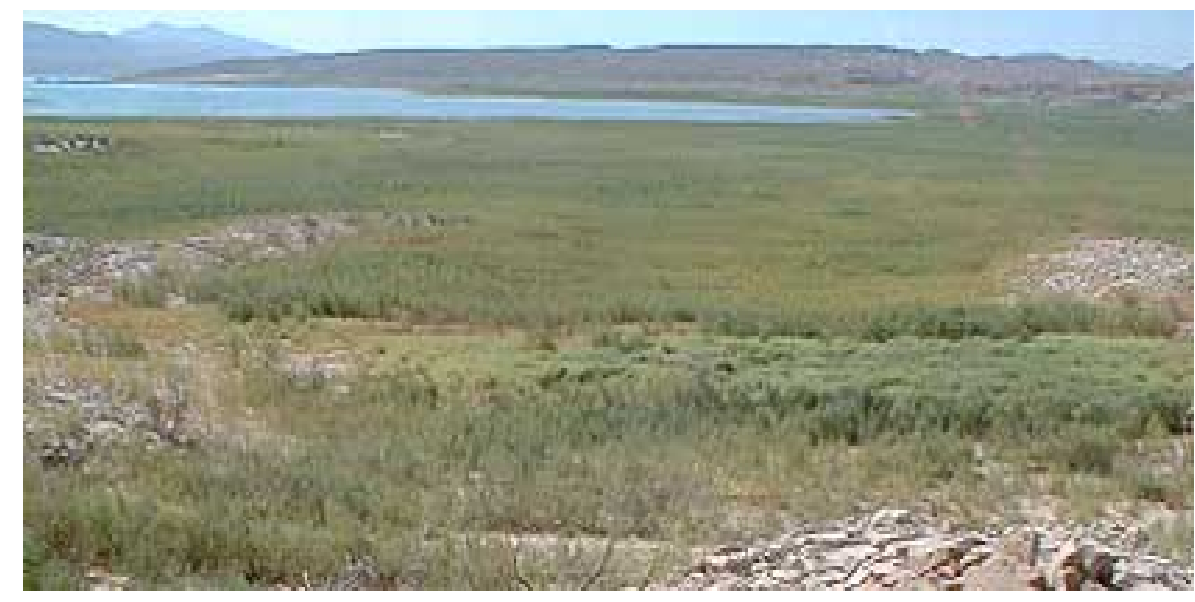

Figure 28: St. Thomas Point overlooking re-emerged area. Note abundant tamarisk growth. Photo taken May 2006.

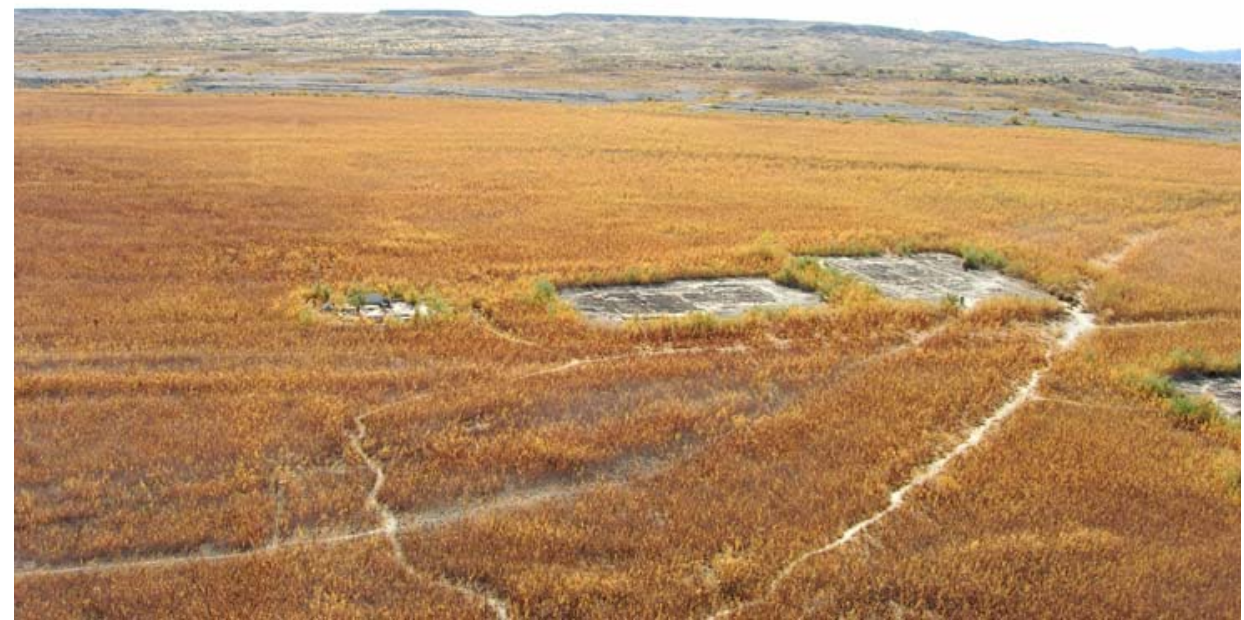

Figure 29: Aerial photo taken during Tamarisk leaf-off. Note abundance of tamarisk and burn areas around remaining structures. Photo source: Lake Mead NRA, January 2003. 
Probes were placed in 11 areas of the study site (Figure 30). Numerous attempts were made to place probes outside of walled structures but, only three were possible due to impenetrable soil. Eight probes were placed inside structures and, each probe indicated that the walled structures contained deposits even though the area surrounding the structure had been severely eroded. 


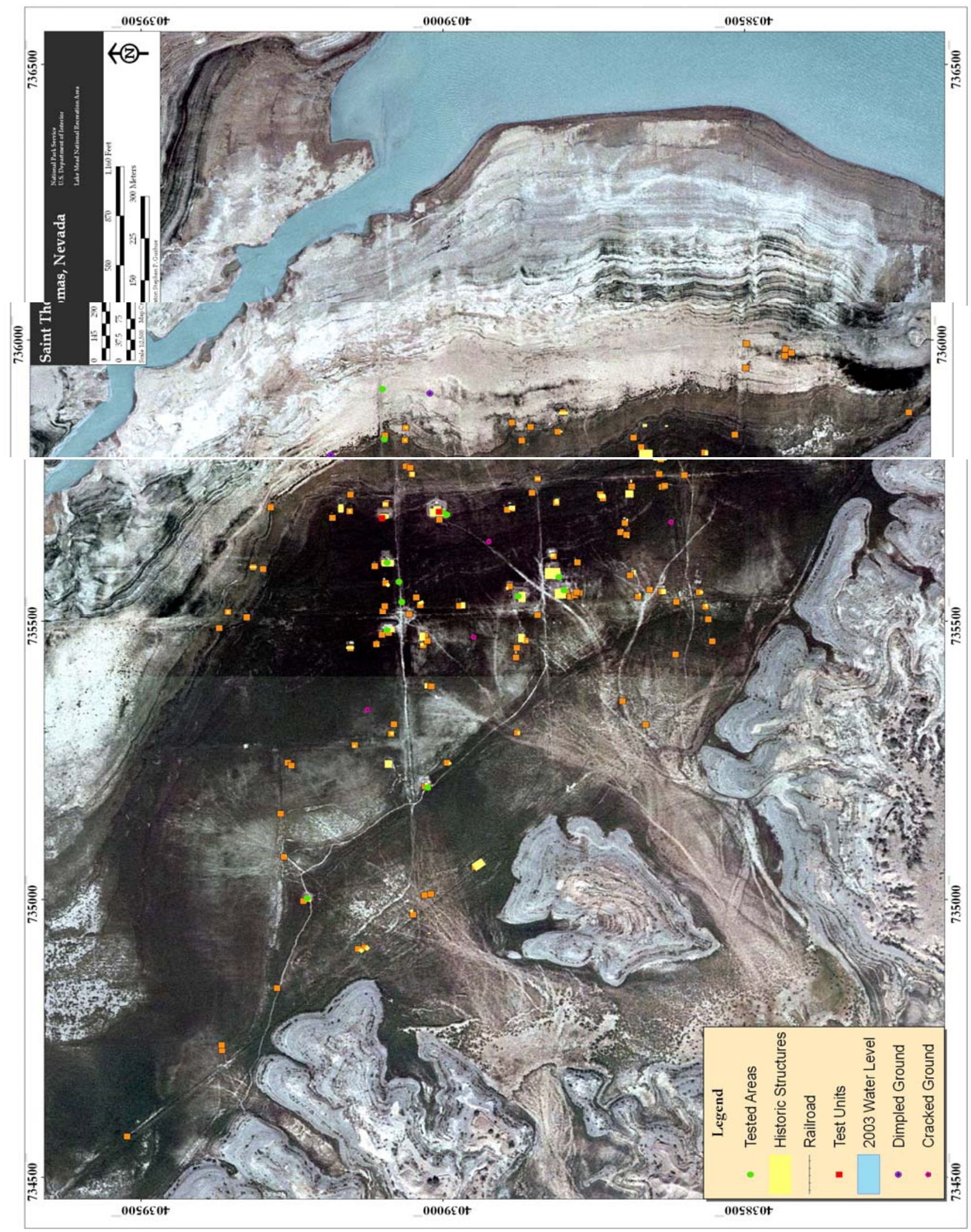

Figure 30: Site map of St. Thomas depicting exposed cultural features, tested areas, excavated test units and ground patterns. Map modified from Gushu, 2005. 
The depth of sediments inside the structures varied from $8 \mathrm{~cm}$ to $>63 \mathrm{~cm}$; which corresponded to the wall height. Structures with basement features and walls extending $10 \mathrm{~cm}$ or less from the ground surface, or containing structural gaps such as doors or windows, contain the most sediment. Evidence supporting this conclusion was found in the oil-changing pit of the auto garage and in the basement of a two level structure where deposits $>63 \mathrm{~cm}$ (Figures 31 and 32). Depth measurement was limited by the probe length and probes placed in the auto garage and oil-changing pit did not reach the terminus of the deposits.

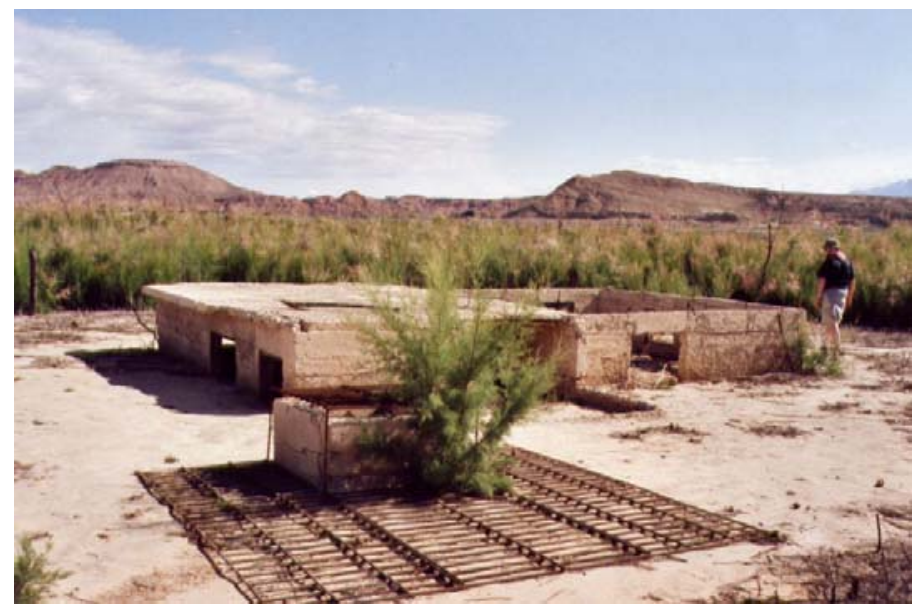

Figure 31: Two level home where deposits are $>63 \mathrm{~cm}$. Photo taken May 2005. 


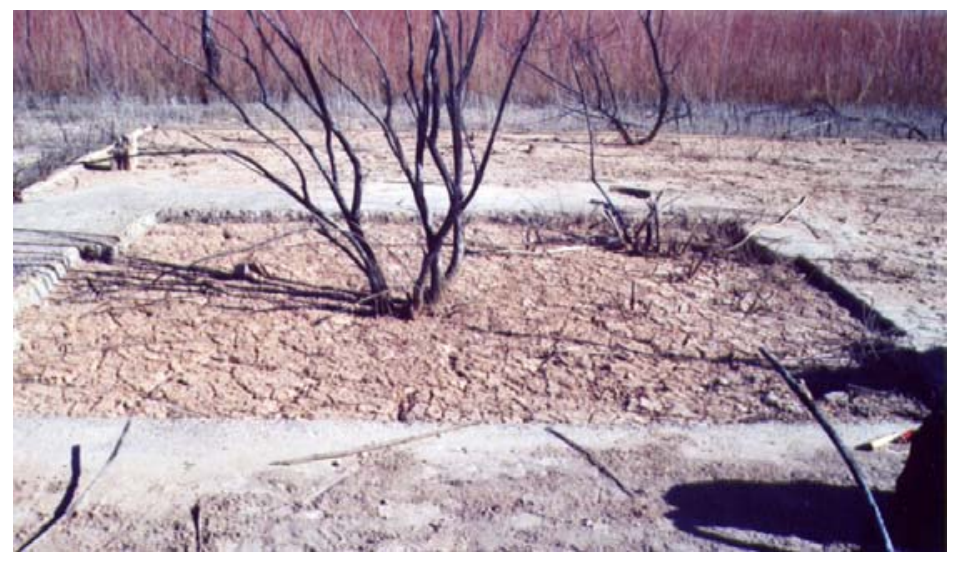

Figure 32: Oil changing pit where deposits are $>63$ cm. Photo taken January 2006.

Visual inspection from the foreshore to the backshore revealed two differing types of ground pattern that are present throughout the case study area. A dimpling pattern was observed within $100 \mathrm{~m}$ of the foreshore (Figure 33). Degassing from pockets in underlying deposited sediments, as seen in Gregg Basin, is ruled out due to the lack of interference with acoustic signaling in the 2001 Woods Hole survey. The origin of this patterning is uncertain and could be the product of spawning or feeding by laucustrine fauna, or could be formed from tamarisk germination. Probes placed in the foreshorepenetrated $5 \mathrm{~cm}$ to cobbles. The surface in the foreshore region recently emerged and supports a habitat of wetland flora and fauna and patches of water worn cobbles occur throughout the area. 


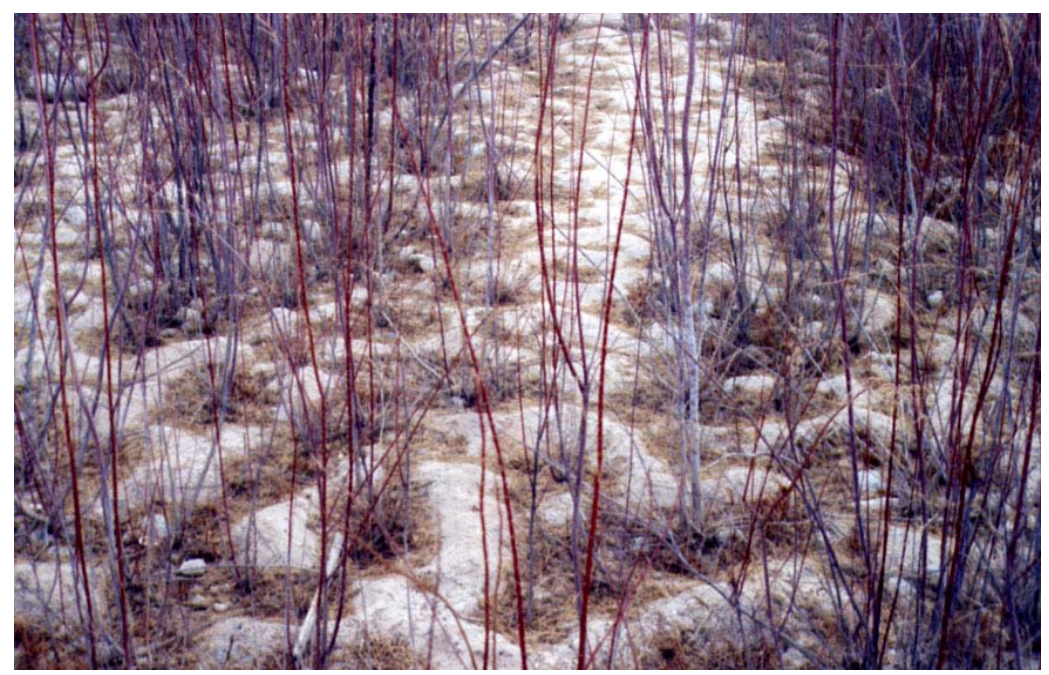

Figure 33: Dimpled pattern observed in the foreshore region. Note tamarisk emerging from center of the dimpled feature. Photo taken January 2006

Further backshore, the dimpled ground changes to cracked ground with fractures as deep as $8 \mathrm{~cm}$ (Figure 34). The placement of probes inside the fractures to penetrate further into the underlying soil proved unsuccessful due to impenetrable soil. Further upslope, the cracked ground gives way to the typical impenetrable flat surface common to the area surrounding Lake Mead. The sediments found throughout this alluvial landscape are characterized by the U.S Department of Agriculture (2006) as the Carrizo series and the texture is a sandy loam. Typically, the sediment of this series are moderately alkaline, contain 0 to 12 percent clay, and average 10 to 85 percent rock fragments depending on geographic setting (U.S. Department of Agriculture, 2006). Particle size analysis conducted for sediment samples collected during this field session confirm the textural description and clay percentages identified by U.S. Department of Agriculture (Table 2) (2006). Gravel percentages do not correlate because flow velocities needed to transport particles $>500$ microns occurred infrequently or not all at St. Thomas. 


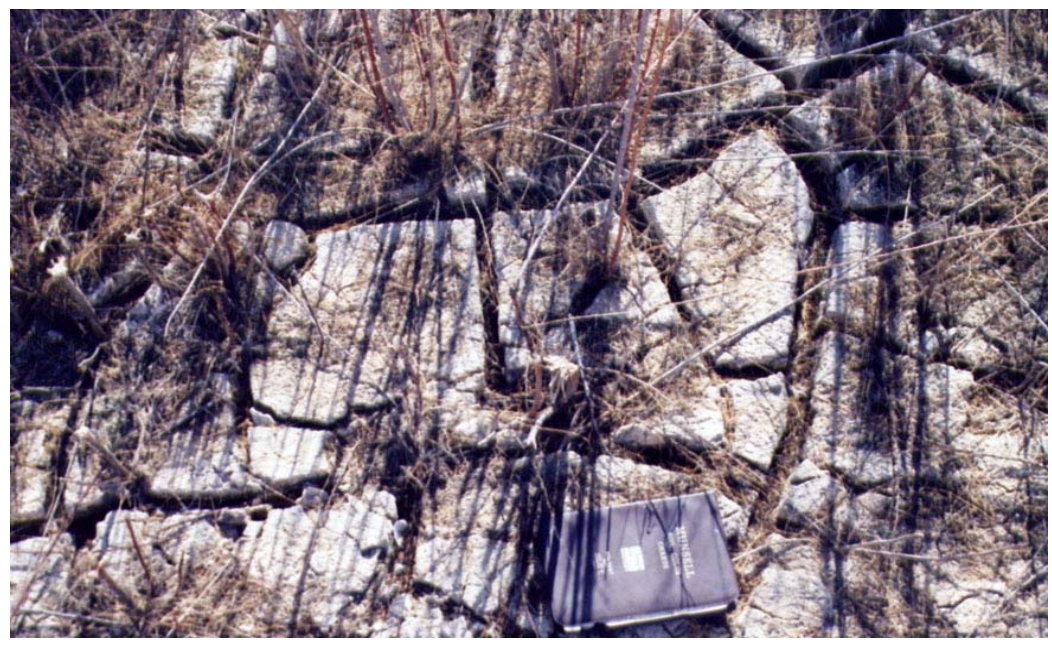

Figure 34: Cracked ground observed further backshore. Mud plates are $~ 5 \mathrm{~cm}$ thick. Photo taken January 2006.

\begin{tabular}{||l|r|r|r|r|r|r||}
\hline \hline & Texture & $\begin{array}{c}\text { \%Gravel } \\
>2000(\mu \mathrm{m})\end{array}$ & $\begin{array}{c}\text { \%Sand } \\
2000 \text { to 62.5 } \\
(\mu \mathrm{m})\end{array}$ & $\begin{array}{c}\text { \%Silt } \\
62.5 \text { to } 3.9 \\
(\mu \mathrm{m})\end{array}$ & $\begin{array}{c}\text { \%Clay } \\
<3.9(\mu \mathrm{m})\end{array}$ & Total \\
\hline $\begin{array}{l}\text { Test Unit 1 } \\
\text { A Stratum }\end{array}$ & $\begin{array}{c}\text { Sandy } \\
\text { Loam }\end{array}$ & $2.62 \%$ & $86.21 \%$ & $8.06 \%$ & $3.07 \%$ & $\sim 100 \%$ \\
\hline $\begin{array}{l}\text { Feature 6 } \\
\text { C Stratum }\end{array}$ & $\begin{array}{r}\text { Silty } \\
\text { Loam }\end{array}$ & $1.90 \%$ & $16.56 \%$ & $66.10 \%$ & $15.42 \%$ & $\sim 100 \%$ \\
\hline $\begin{array}{l}\text { Test Unit 1 } \\
\text { C Stratum }\end{array}$ & $\begin{array}{c}\text { Sandy } \\
\text { Loam }\end{array}$ & $1.42 \%$ & $52.02 \%$ & $30.93 \%$ & $15.61 \%$ & $\sim 100 \%$ \\
\hline $\begin{array}{l}\text { Garage Pit } \\
\text { C Stratum }\end{array}$ & $\begin{array}{c}\text { Sandy } \\
\text { Loam }\end{array}$ & $2.48 \%$ & $69.06 \%$ & $19.58 \%$ & $8.86 \%$ & $\sim 100 \%$ \\
\hline
\end{tabular}

Table 2: Percent of gravel, sand, silt and clay fraction in each sediment sample.

The type of clay present at St. Thomas is of particular interest to this research. Four soil samples were tested using XRD to determine if smectictes were present. Smectites are a group of 2:1 phyllosilicate clay minerals, with two tetrahedral silica sheets sandwiching a central octahedral alumina sheet. Expansion occurs when smectites are wetted, due to a potassium deficiency that creates weak interlayer bonds, that allows water to penetrate the interlayer space (Warshaw and Roy, 1961). This shrink-swell activity could also be a factor contributing to structural instability. To determine the presence or absence of smectites in deposits at St. Thomas, XRD analysis of four 
sediment samples were prepared following procedures outlined by Warshaw and Roy (1961) and Kite and Bell (1992). Figure 34 is a visual indicator of the type of ground cracking that typically occurrs when smectites are present.

\section{Aerial Photography}

At the beginning of this research it was hypothesized that the origin of depositional sediments at St. Thomas derived from turbidity currents of one or a combination of three river sources: Muddy, Virgin or Colorado rivers. Eight specific stereoscopic aerial images found at Whittier College's Fairchild Collection proved valuable in assessing St. Thomas's pre-inundation land-use patterns. These images confirm written documentation describing the intensive agricultural practiced at St. Thomas prior to inundation (Figure 35). 


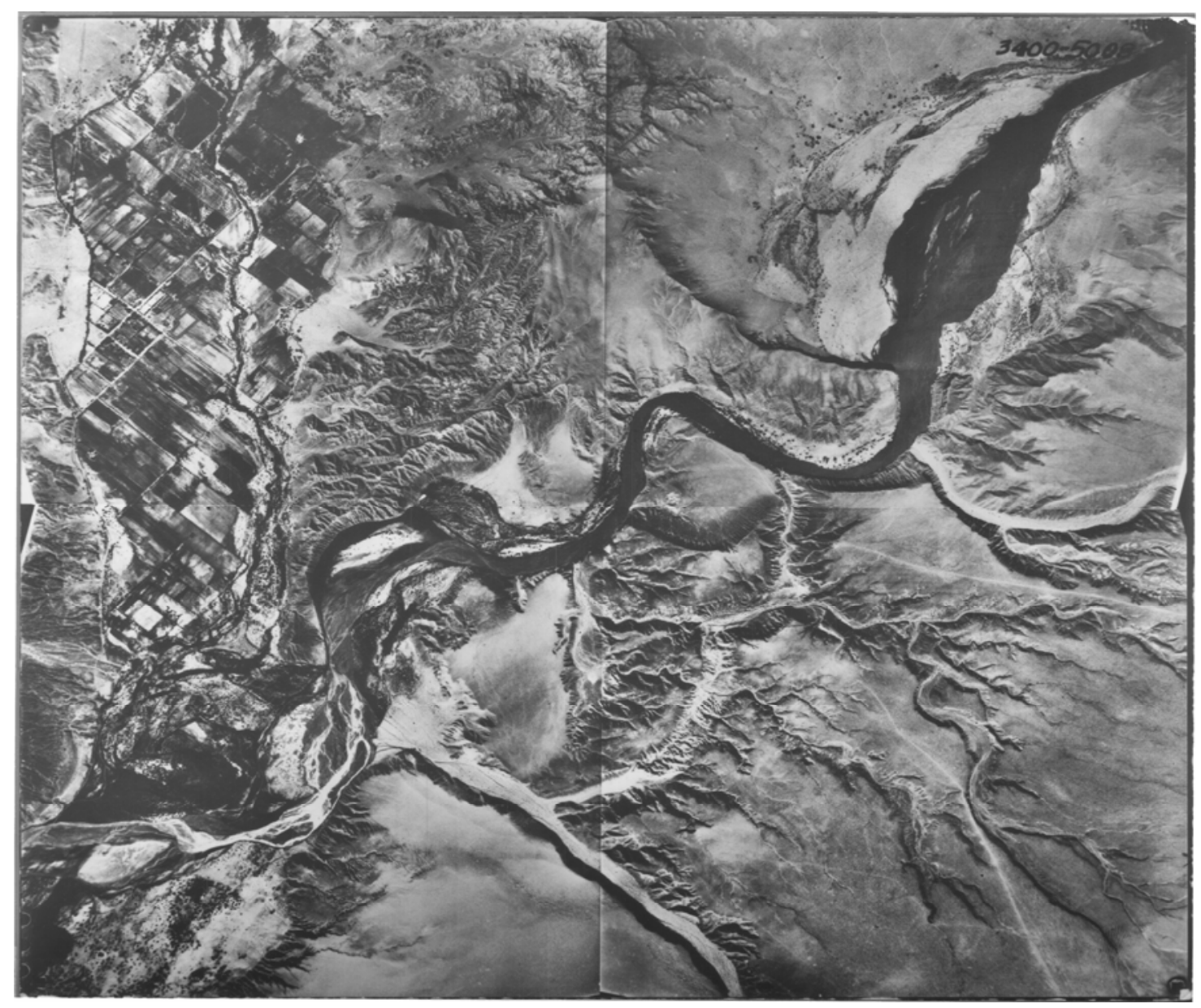

Figure 35: Aerial photo acquired in 1925 by the Fairchild Corporation prior to submersion of St. Thomas and surrounding area. Note agriculture in the upper and central left portion of the image. The Virgin River is flowing from the upper right corner to the southwest and the Muddy River from the upper left to the south. Photo source: Whitter College Fairchild Collection Whitter, California.

These images also provided information as to another possible source of deposits that accumulated within the structures at St. Thomas. Mansfield (1937), while researching flood deposits after the 1937 Ohio River flood, noted the presence of thick sediments within structures after floodwaters receded. Since then, local, state and government agencies have recognized sediment accumulation within structures as a serious hazard to human safety and now prescribe detailed instructions as to the best methods of removing the deposits (Ulirsch et al., 2002). 
Agricultural lands are typically mantled by loose uncompacted sediments found along the floodplains. Sediments in floodplains will remain in storage within the fluvial system until a stream exceeds the threshold basal stream stress for bedload entrainment (Knighton, 1998). Loose, uncompacted, stored sediments become active and are entrained by increased flow velocities and remain in transport until flow velocities decrease to create deposits (Knighton, 1998). Examples of this were seen in the 1993 flood of the Missouri and Lower Mississippi River Valleys (U.S. Army Corps of Engineers, 1993). During this flood event agricultural communities sustained the most damage and post-flood reports indicated that the flood left farmland covered with sand, silt, driftwood and other debris (U.S. Army Corps of Engineers, 1993).

Similar effects may have occurred at St. Thomas when the waters of Lake Mead were rising. Loose uncompacted agricultural sediments in an inactive state became entrained and dispersed throughout the site until flood velocities decreased and lake elevations increased sufficient to deposit the material and create a stable submerged environment. Structures with intact walls or basements acted as sinks and preserved these deposits, while the remaining sediments were eroded or scoured away during re-emergence. As discussed, these situations are typically seen in areas where flooding occurred and sediment is often found in basements, closets, and enclosed foundations.

A visual inspection of St. Thomas supports this hypothesis and confirms the theory that intensive erosional processes were occurring in periods of reservoir down-draw. For instance, structures such as the St. Thomas Schoolhouse or blacksmith shop contain deposits of $20 \mathrm{~cm}$ or more. The forepart of the structure shows wind-wave erosion where waves have lapped against the walls and eroded the historic settlement strata away 
leading to structural undercutting typically seen in reservoirs experiencing pool-level shallowing (Figure 37) (Thorne, 1991 and 2004). In the rear-part of the structure, where wave action dissipates after initial contact with the front of the structure, C and A strata remain.

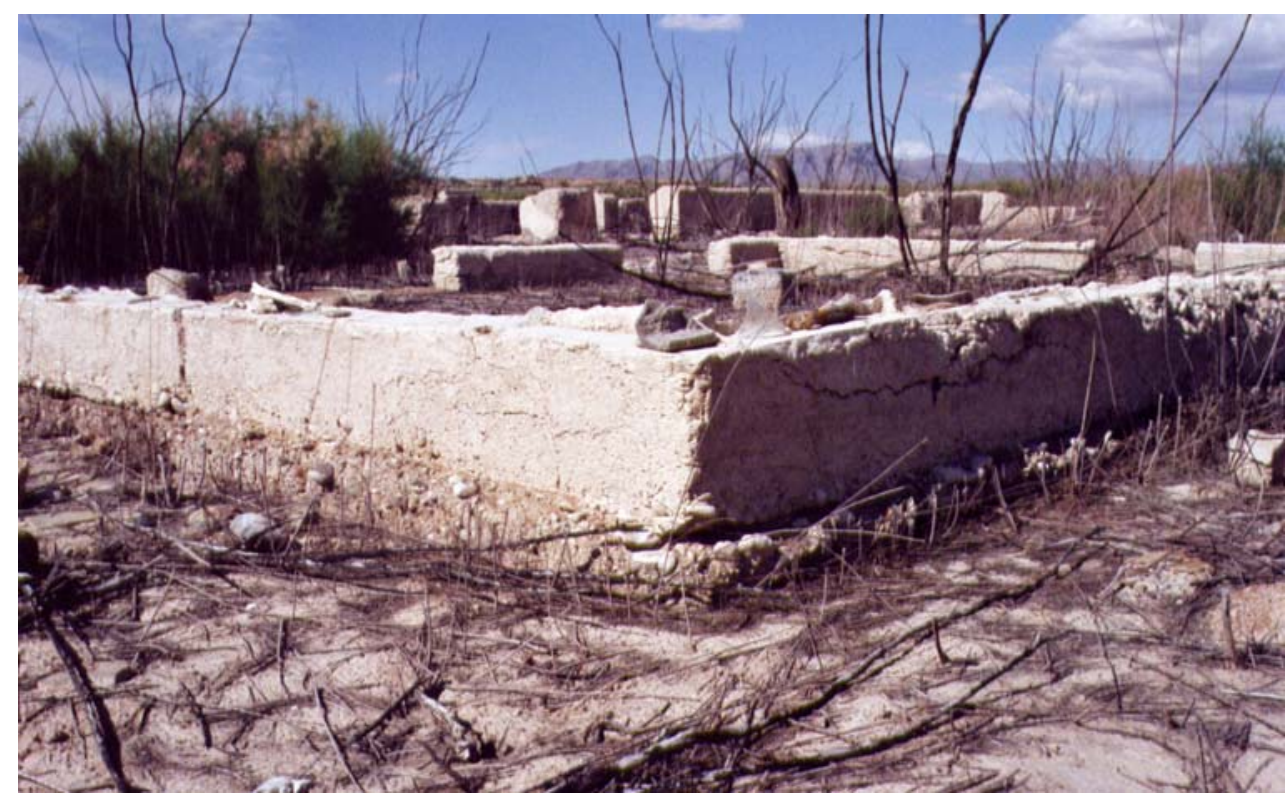

Figure 36: Gentry garage. Note cracks in walls where tamarisk have penetrated. Photo taken May 2005.

\section{Submerged Environment}

Distinct thermal layers and boundaries exist in lakes and reservoirs: including epilimnion, thermocline and hypolimnion (Figure 37) (Lenihan et al., 1981). The uppermost epilimnion layer supports photosynthetic activity needed to establish aerobic organisms, while the cooler hypolimnion supports bacterial activity (Lenihan et al., 1981). Distinct thermoclines exist in Lake Mead during the summer months. The first thermocline occurs around $9 \mathrm{~m}$ to $13 \mathrm{~m}$ with the upper epilimnion averaging $\sim 21{ }^{\circ} \mathrm{C}$ to $\sim 26{ }^{\circ} \mathrm{C}$, that supports algae and aerobic activity (U.S. National Park Service, 2006). A second thermocline occurs at $18 \mathrm{~m}$ with the waters in between averaging $\sim 15{ }^{\circ} \mathrm{C}$ to $\sim 21$ ${ }^{\circ} \mathrm{C}$. This thermocline supports a lesser density of algae, below $18 \mathrm{~m}$ temperatures range 
from $\sim 15 \quad{ }^{\circ} \mathrm{C}$ to $\sim 11 \quad{ }^{\circ} \mathrm{C}$ (U.S. National Park Service, 2006). Typically, no thermoclines exist during winter months when the entire water column remains at $\sim 10{ }^{\circ} \mathrm{C}$ (U.S. National Park Service, 2006).

St. Thomas becomes submerged under $\sim 18 \mathrm{~m}$ of water during high water episodes. Intact timbers found in test unit two, along with exposed wood fence posts and tree stumps, indicates that extended periods of anaerobic activity occurred when water levels are high enough to decrease oxygen and sunlight. This submerged environment creates ideal anoxic, oxygen restricted, conditions that regulate aerobic organisms.

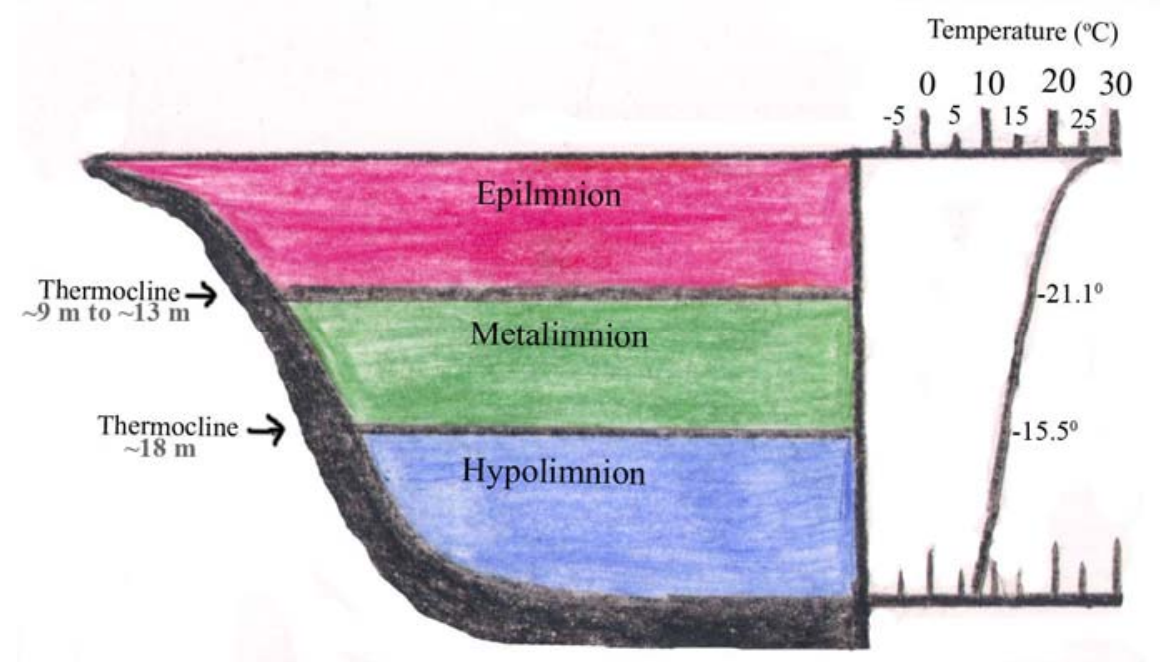

Figure 37: Thermal stratification of Lake Mead during summer months.

Asiatic freshwater clams (Corbicula fluminea) occur in abundance in test units one and two. This invasive burrowing clam was introduced to the western United States in the 1920s. This species thrives in well oxygenated lotic and lenthic habitats with substrates comprised of fine sand, clay or coarse sand (Figure 38) (Blalock and Herod, 1999). Lotic habitats are characterized as moving water environments such as are found in the littoral zone of lakes and other large bodies of water that experience changes in water level (figure 38) (Blalock and Herod, 1999). Lenthic environments pertain to still or slow moving water habitats as found in the limnetic zone of deep lakes (Figure 38) 
(Blalock and Herod, 1999). Bioturbation from this species of freshwater clam obliterated the horizontal bedding of deposited sediments and erased any evidence of bedding or lamina as seen during excavation of test units one and two.

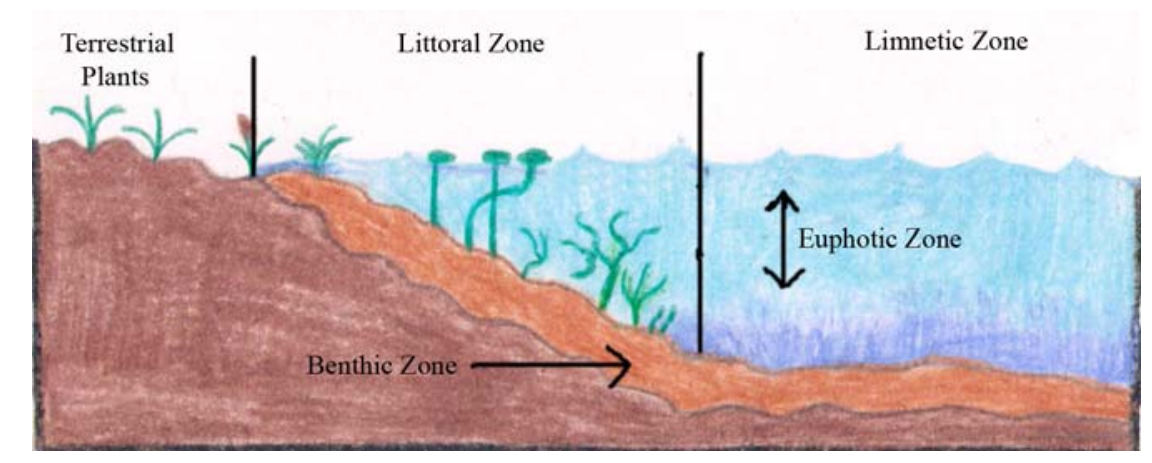

Figure 38: Biological zones associated with the physical structure of lakes.

During inundations, impacts upon cultural resources, especially organics, from invasive biological species are regulated by dissolved oxygen concentration and light penetration (Lenihan et al., 1981). These variables regulate the presence and activity of aerobic organisms and bacteria that degrade submerged cultural resources and alter site stability by limiting the oxygen concentration needed to sustain nutrient sources that ensure and support their viability.

A visual survey of St. Thomas identified several wood fence posts and remnant trees from historic occupation. Excavation of the St. Thomas Schoolhouse and blacksmith test units unearthed considerable wood fragments and intact timbers in the C strata, and to a lesser extent in the A strata. The intactness of these artifacts suggests that biologic activity was negligible, especially within structures containing deposits. As discussed by Lenihan et al. (1981), sedimentation can enhance preservation by buffering biological 
and mechanical processes that degrade artifacts, by regulating the presence of dissolved oxygen, light and water-borne nutrients and acting as a protective buffer from erosional forces caused by water oscillation or other fluid forces. This evidence suggests that during continual submergence, anoxic conditions create an anaerobic environment that is optimal for artifact preservation.

\section{Variables Contributing to Erosion}

Fieldwork sessions conducted in May 2005 and January 2006 revealed erosion occurring at small and large scales. This section takes an in-depth look at those variables most responsible for site degradation and instability.

Tamarix ramosissima has taken over the lake margins at St. Thomas and continues to propagate in areas where pool-level shallowing occurs. Written documentation suggests a coniferous, less invasive species of tamarisk, Athel tamarisk, was cultivated during the 1890s at St. Thomas for shade and as an erosion control along irrigation ditches (McClellan et al., 1980). Photos taken circa 1935 (Figures 39 and 40), during the initial evacuation of St. Thomas, shows mature Athel tamarisk lining roadways and ditches. This species of tamarisk is an evergreen variety, not the deciduous species that inhabits monotypic stand at St. Thomas today. 


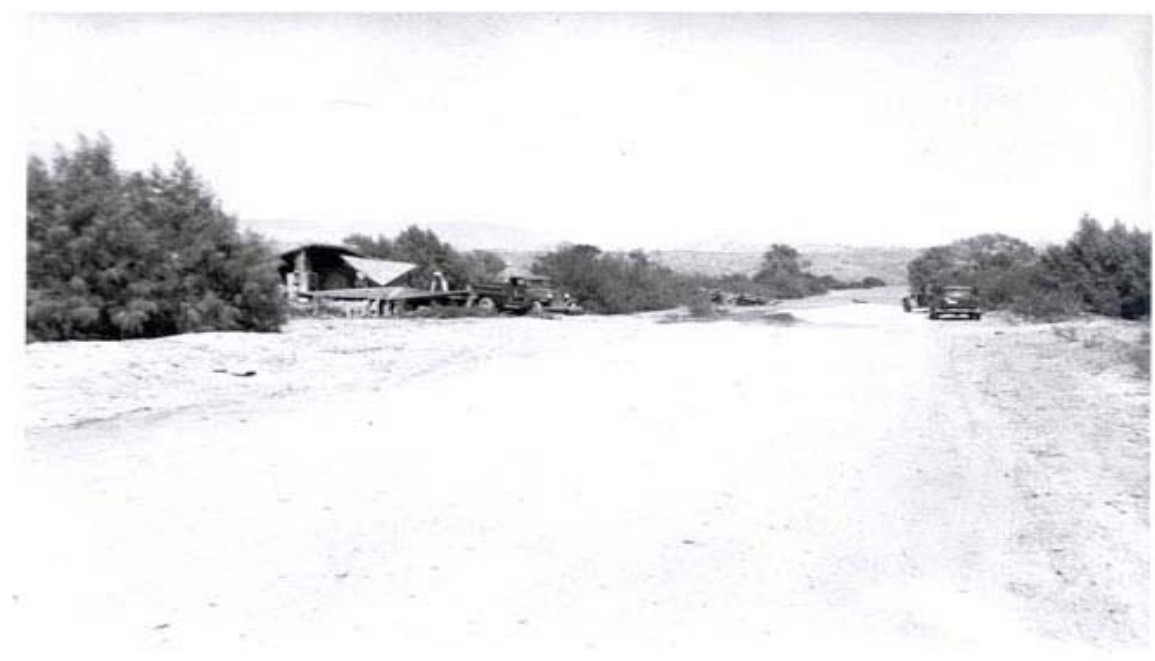

Figure 39: Homestead removal circa 1935. Note Athel tamarisk lining both sides of roadway. Photo source: University of Las Vegas Lied Special Collections Library.

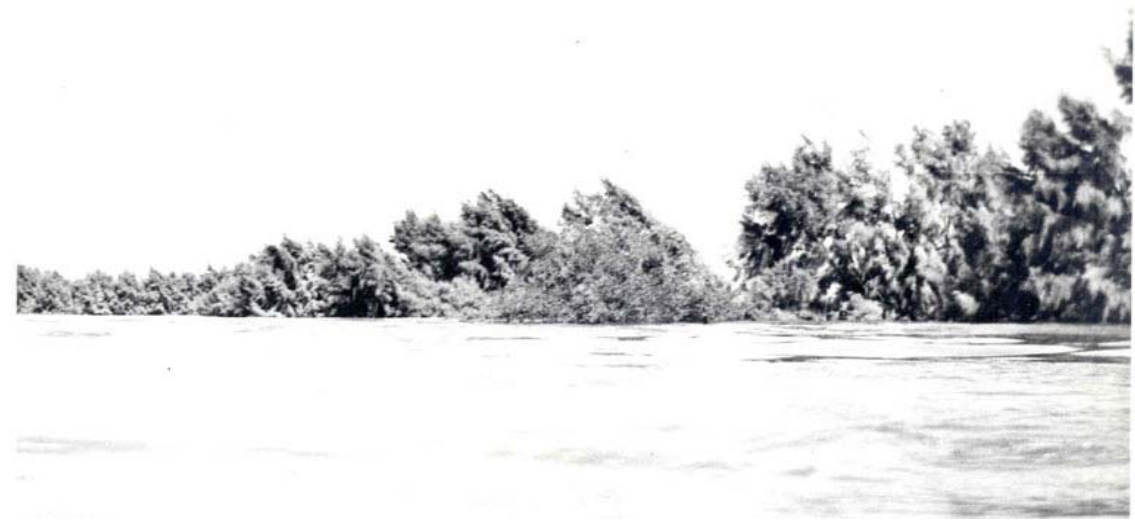

Figure 40: Rising Lake Mead waters on highway 91. Note Athel tamarisk lining roadway. Photo source: University of Las Vegas Lied Special Collections Library.

Tamarix ramosissima propagates well in lake side margins. This species of tamarisk produces massive quantities of seeds that are wind dispersed and can remain viable for up to 45 days until germination upon contact with water. Germination can take place within 24 hours of contact with water (Carpenter, 1998). 
The area around St. Thomas supports the habitat needed to spread and grow deciduous tamarisk. Factors that facilitate the spread of tamarisk within the reservoir margins of Lake Mead include large areas of fine sediment along the reservoir margins that provide the ideal substrate for tamarisk colonization, gradual reservoir down-draw and abundant ground water. These factors result from regulating the water flow along the Colorado River.

The presence of tamarisk at St. Thomas compromises the stability of structures through the ability of the plant to break foundations and walls (Figure 36). Prescribed burn efforts made by Lake Mead NRA’s Exotic Plant Management Team were successful in removing tamarisk from specific structures. However, the fecundity of the species in combination with increases in pool-level during the spring, and shallowing in mid to late summer, allows seeds cast during the months of October through April an opportunity to germinate during the moister spring conditions and take hold during the hotter months. Deterring further damage to the remaining structural features will require theaggressive removal and maintenance of tamarisk. Prescriptive burns have been the standard method of removal. These burns must be closely monitored in order to deter cultural resource losses from fire damage. The total removal of tamarisk is required to restore the noninvasive willow and cottonwood habitats that typically populate the reservoir's margins and will restore ecological equilibrium throughout St. Thomas. However, Tamarix ramosissima's ability to thrive and spread within the lake margins makes this scenario unlikely. 


\section{Mechanical- Seiche/Wind-Wave Action}

The magnitude of erosion from wind-wave action is dominant in sites experiencing intermittent inundation due to pool level fluctuation. Water depth determines the magnitude of wave erosion at St. Thomas. Thus, when Lake Mead is in a state of downdraw, sites that were once in a deep-water state of relative equilibrium become susceptible to mechanical erosion induced by pool level shallowing.

Seiches are defined as a standing wave or the oscillation of water in a partially or fully enclosed body of water (Leifson, 1948). Wind speed, wind direction and water depth are the primary variables controlling seiche patterns in Lake Mead. A survey of Lake Mead by the U.S. Geological Survey (1948) revealed considerable seiche action during periods of moderate to strong winds. Varying patterns exist from short-period, small-amplitude oscillations to long-period cycles of varying amplitude (Leifson, 1948). The axis of prevailing wind in Lake Mead is north and south (Leifson, 1948). Re-emergent beach ridges that appear as crenulations in the foreshore of photos taken in June 2003 of St. Thomas indicate that the predominant wind direction orientate the waves approaching land (Figures 41, 42 and 43). Also visible in Figure 42 is a re-emerging structure and waves striking the walls, lending evidence to the mechanical stresses that structures incur from lapping waves during reservoir down-draw. 


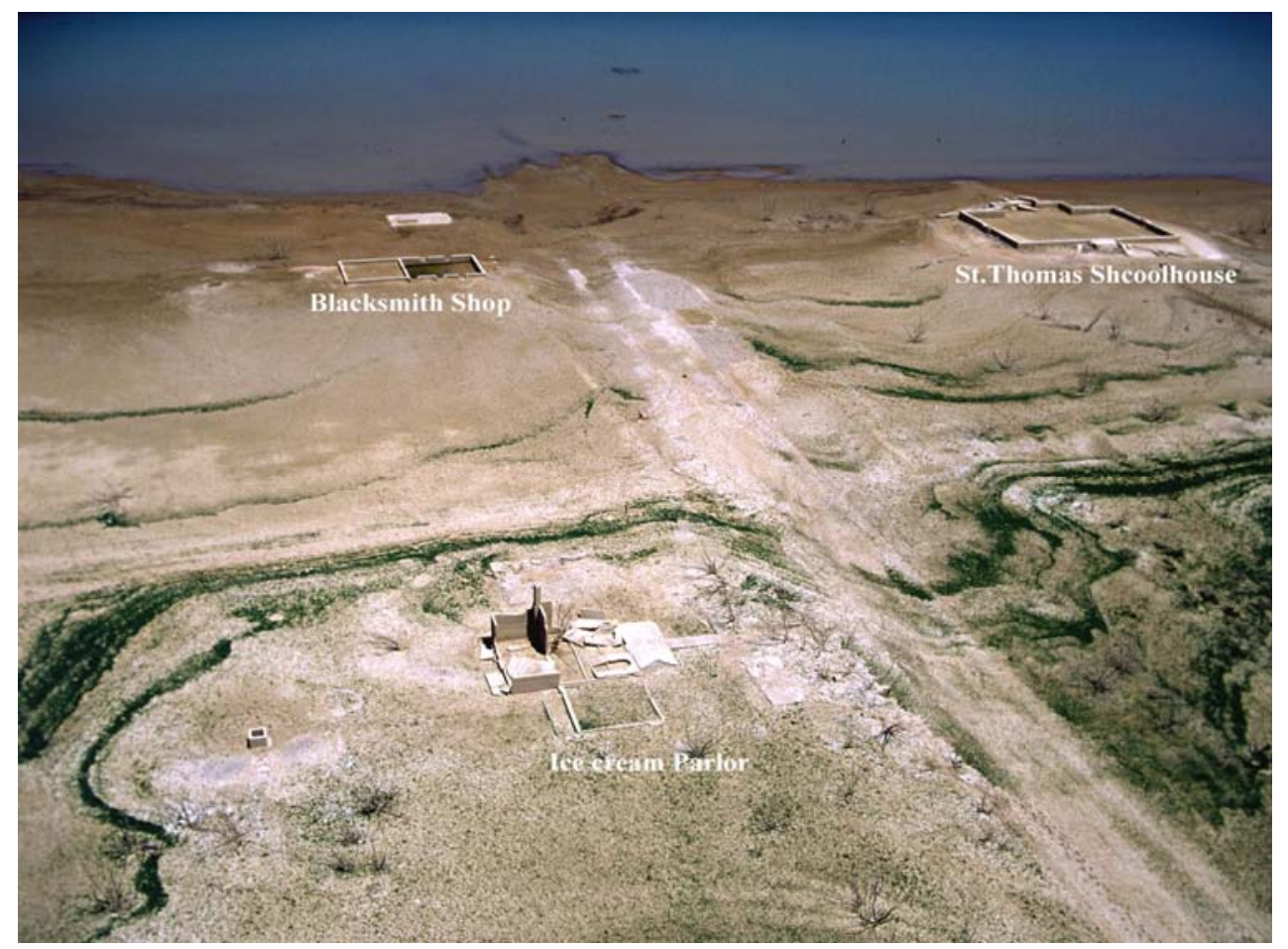

Figure 41: Aerial photo taken June 2003. Re-emergent beach ridges appear as crenulations in the foreshore. Same as figure 42 and 43 but from opposite direction. Photo source: Lake Mead NRA.

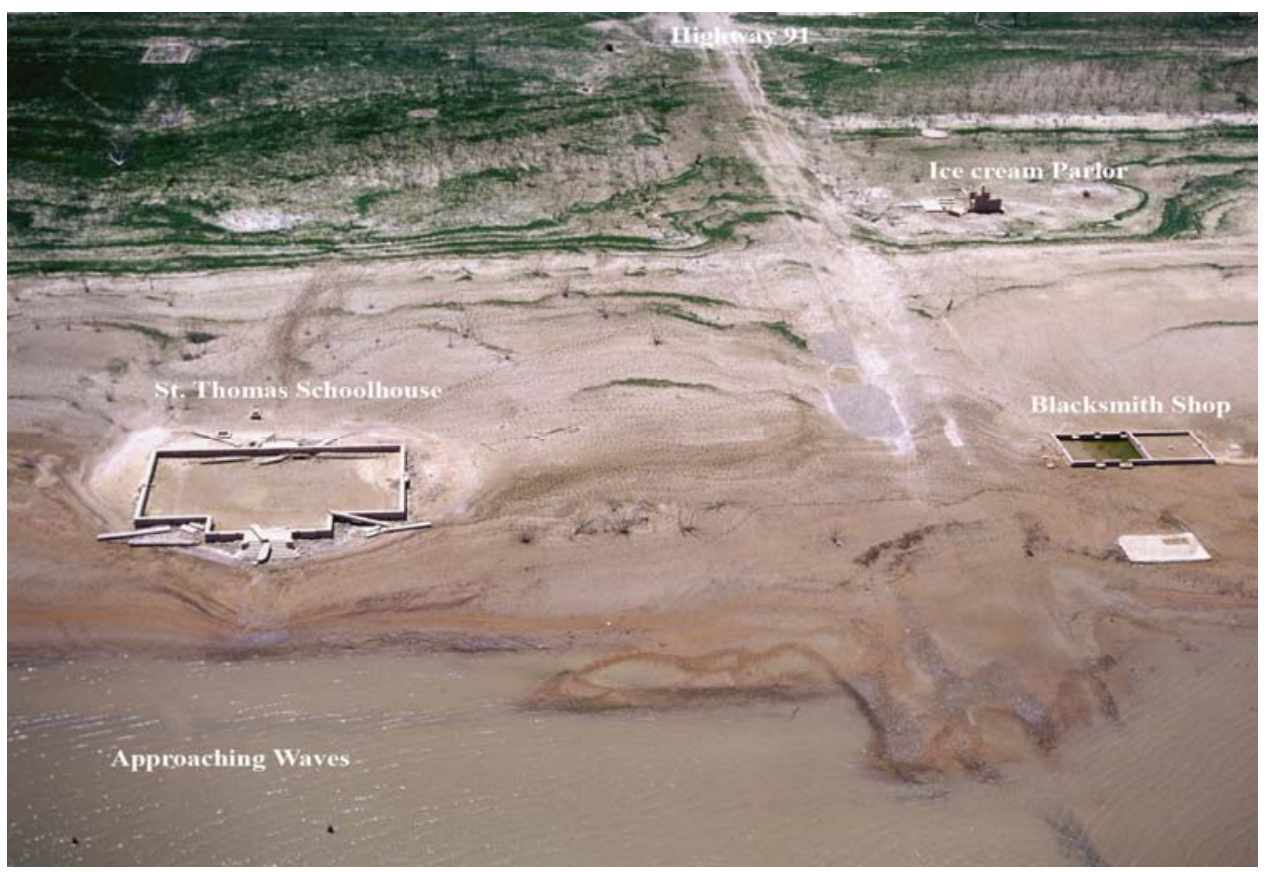

Figure 42: Aerial photo taken June 2003. Re-emergent beach ridges appear as crenulations in the foreshore and note re-emerging structure. Note orientation and direction of approaching waves. Photo source: Lake Mead NRA. 


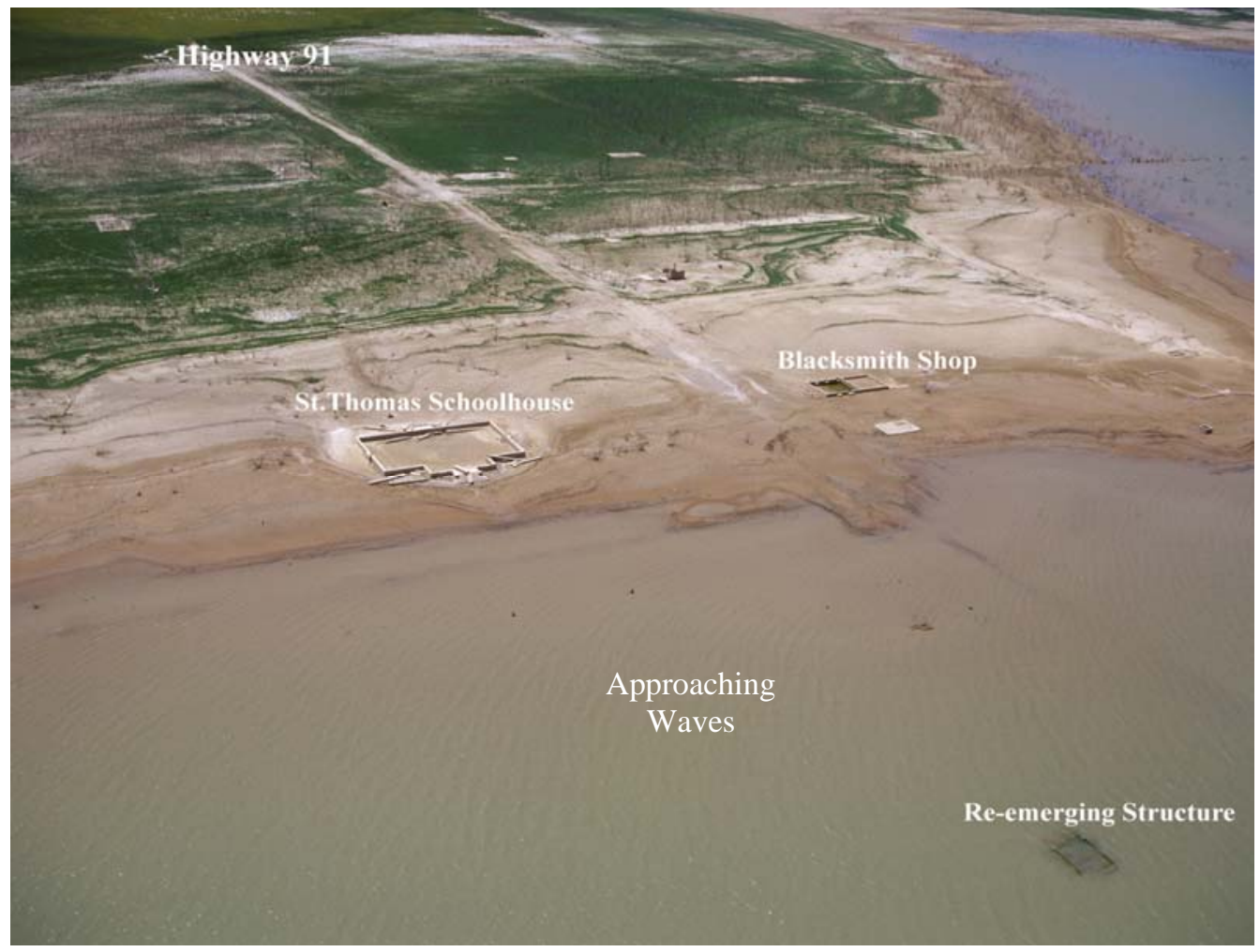

Figure 43: Aerial photo taken June 2003. Re-emergent beach ridges appear as crenulations in the foreshore and note re-emerging structure. Photo source: Lake Mead NRA.

\section{Large-Scale Erosional Activity}

The erosional processes discussed thus far operate on a small scale. Small-scale processes alter the stability of the landscape and structures through physical erosional forces generated from wind-wave action and biologic intrusions affecting the ecological equilibrium between native and invasive species.

Other forms of erosion occurring at St. Thomas operate on a large scale. These processes do not alter the stability and equilibrium of larger landforms. Rather, they operate on a feature-by-feature basis. The freeze thaw (Figure 20) and mineralogical composition (Figure 44) of sediments deposited within structures affect the foundational stability of the remaining features at St. Thomas. As previously discussed, spalling 
occurs throughout St. Thomas (Figure 20). Although St. Thomas is situated in the Mohave Desert, which is known for its extreme heat, desert environments experience extreme temperature fluctuations throughout the day. The average minimum temperature for the area around St. Thomas from November to February is at, or near, freezing, creating an ideal environment for freeze-thaw action to occur (U.S. National Park Service, January 2006). Figures 44 and 45 illustrate the types of damage that a structure may incur if shrink-swell clays are present. Foundations may become warped due to the constant expansion and contraction, or walls may begin to crack and separate (Figure 45). The movement generated from both freeze-thaw and shrink-swell weakens the structural material and increases instability. 


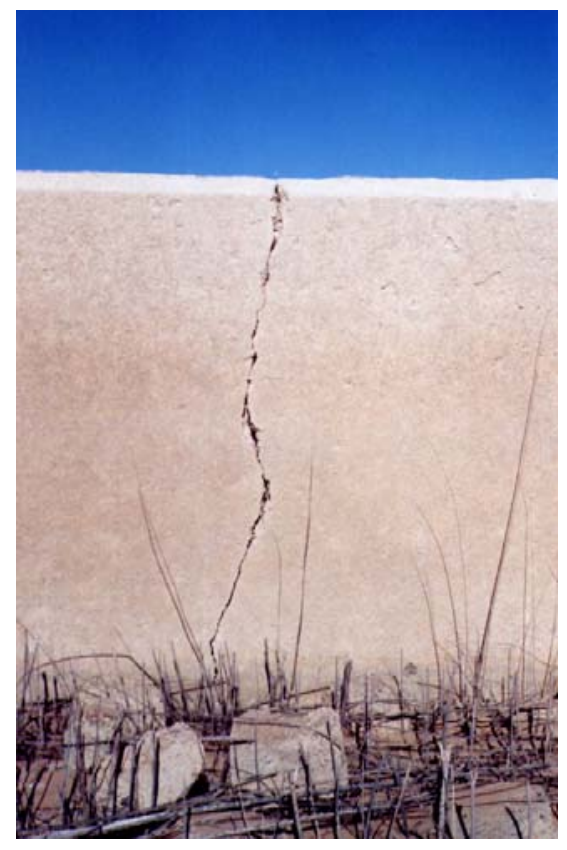

Figure 44: Cracking on St. Thomas Schoolhouse wall. Photo taken January 2006.

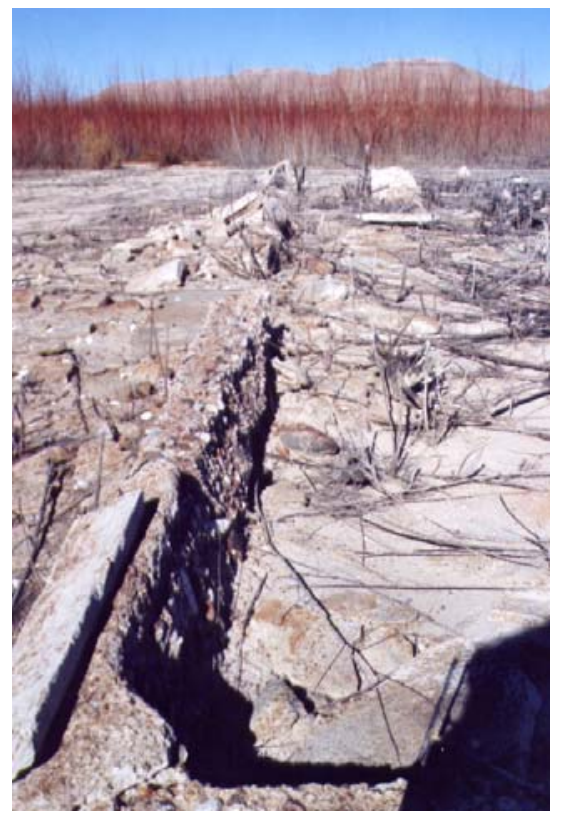

Figure 45: Foundation separation on Gentry Store. Photo taken January 2006.

Deposits accumulated within structures compromise structural stability if smectites, shrink-swell clays, are present. The interlayer distance or d-spacing between silicate sheets prior to the introduction of an expansion agent, ethylene glycol, typically are $14 \AA$ but reach $17 \AA$ after glycolation. Table 3 lists characteristics such as origin, strata 
location and the treatment number of each sample. Figures 46 to 55 illustrate d-spacing, peaks and patterns for identified minerals in each sediment sample before and after glycolation.

\begin{tabular}{|c|c|c|}
\hline Sample Strata & Non-glycolated sample & Glycolated Sample \\
\hline $\begin{array}{c}\text { Feature 6 C Stratum Two } \\
\text { Level House }\end{array}$ & TT_3 & TT_3_A \\
\hline Garage Pit C Stratum & B_51 & B_51_A \\
\hline Test Unit 1 A Stratum & DS_24 & DS_24_A \\
\hline Test Unit 1 C Stratum & E_1 & E_2_A \\
\hline
\end{tabular}

Table 3: Sediment sample origins and test numbers. 


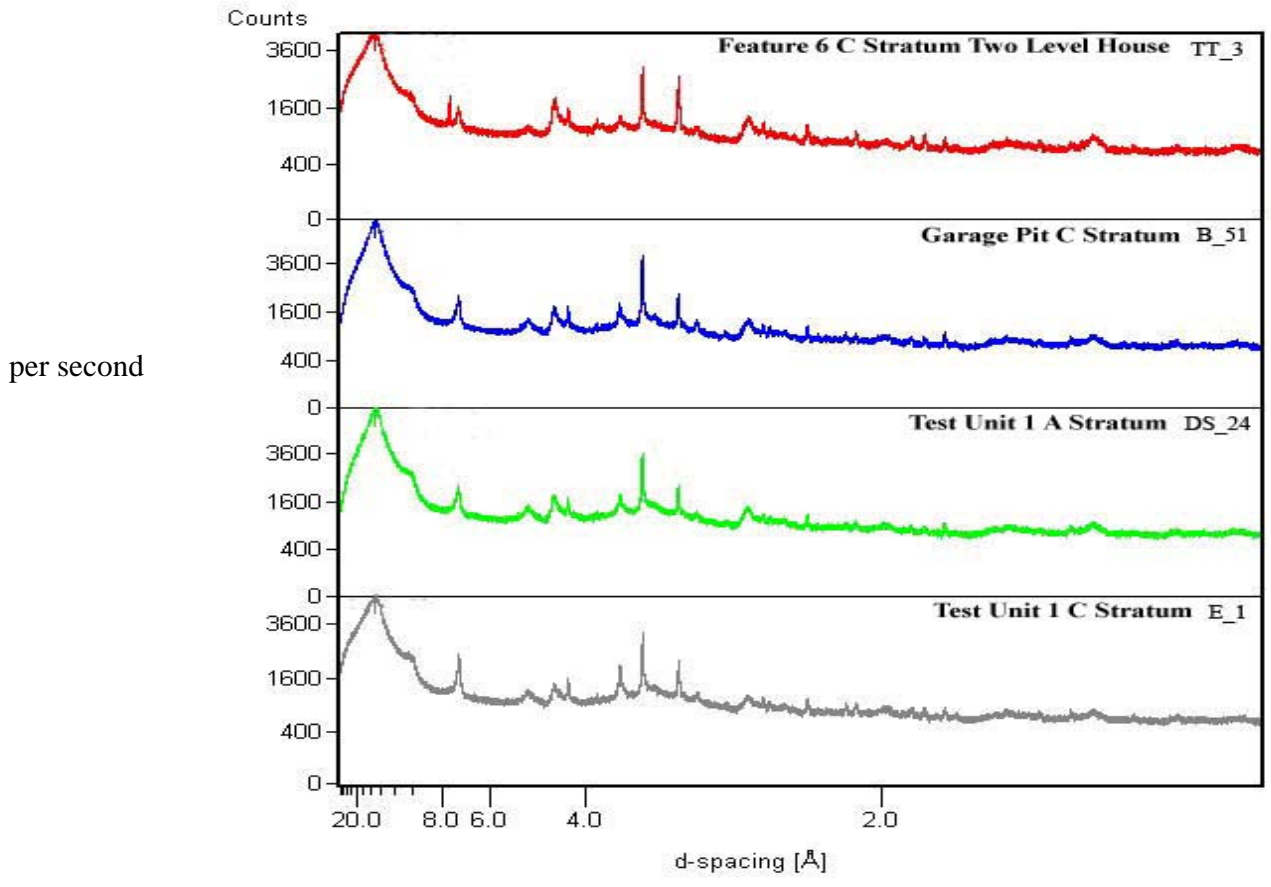

Figure 46: Clay mineral peaks and patterns for four sediment samples. Note similar profile and mineral peaks for each sample.

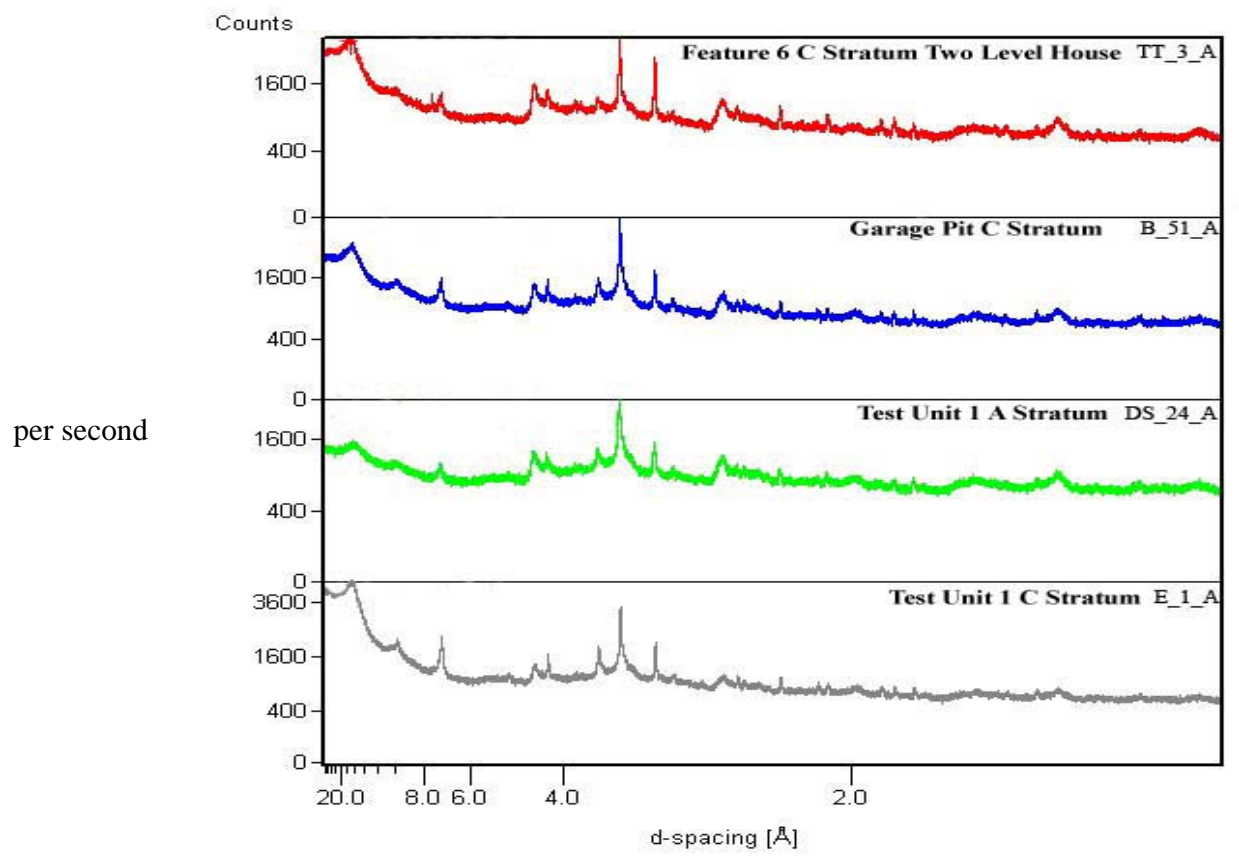

Figure 47: Clay mineral peaks and patterns for four sediment samples after ethylene glycol treatment. Note similar shift in smectite peak in each sample. 


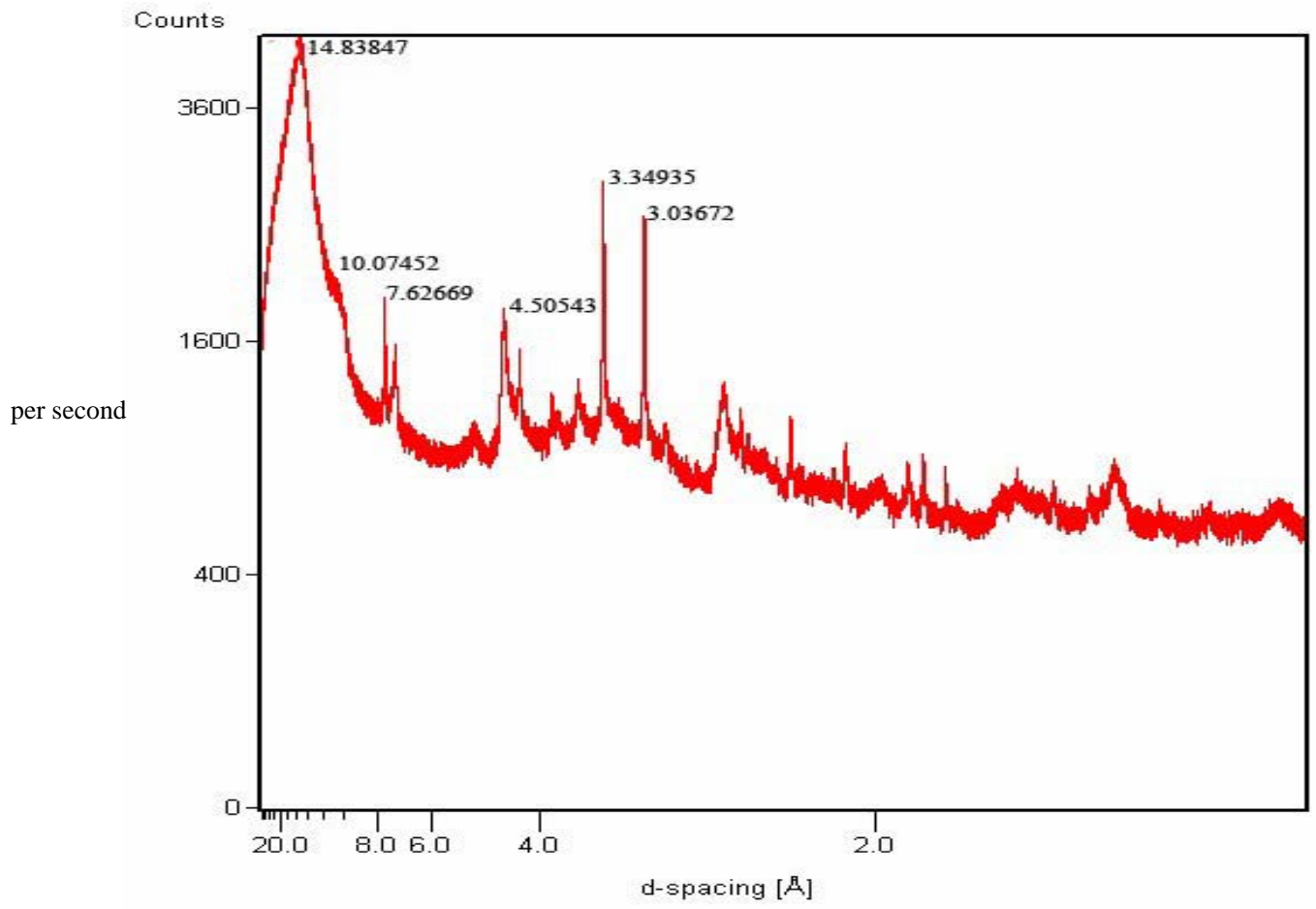

Figure 48: Sample TT_3, from Feature 6, d-spacing and peaks for identified minerals.

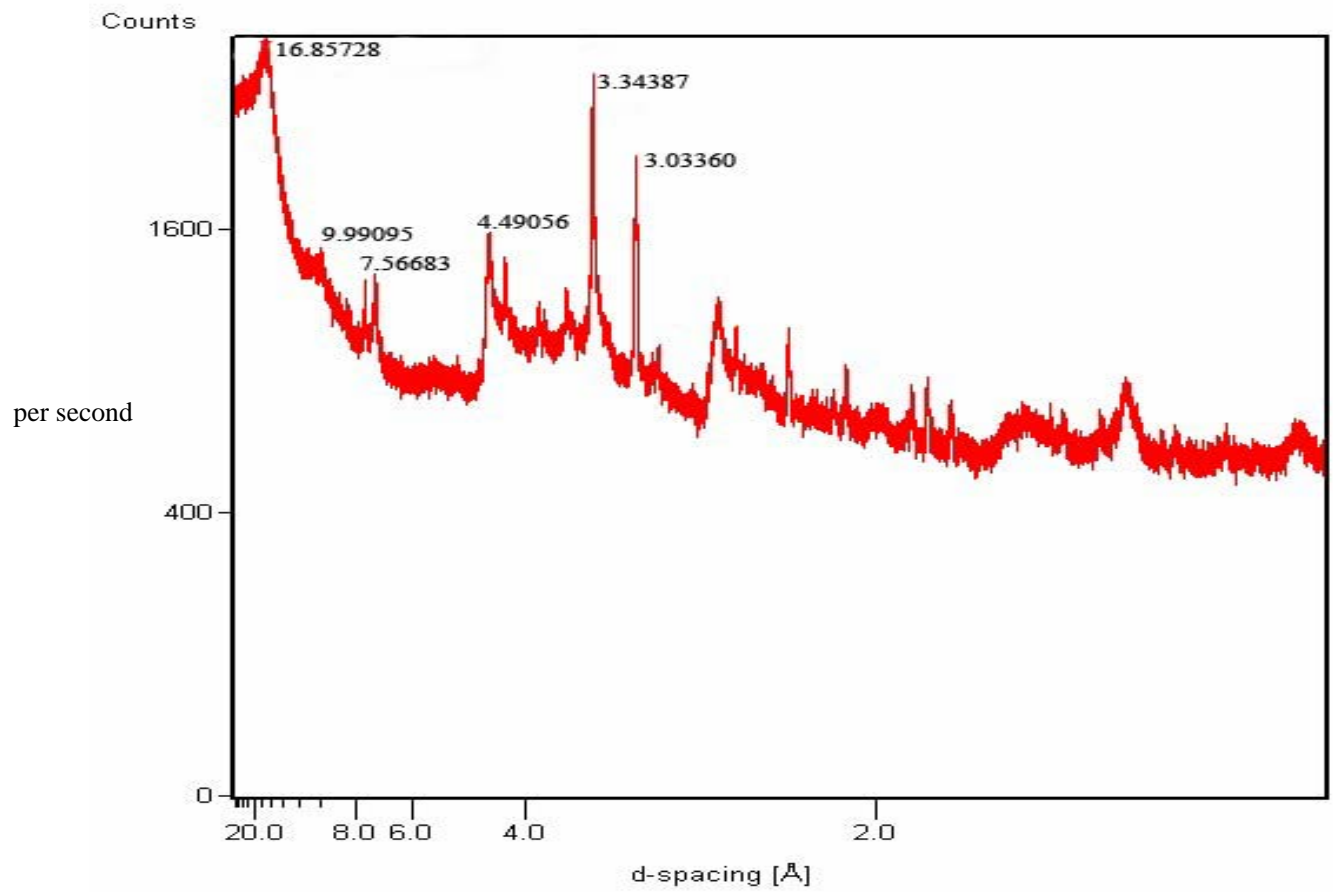

Figure 49: Sample TT_3_A, from Feature 6, d-spacing and peaks for identified minerals after ethylene glycol treatment. Note shift in smectite peak. 


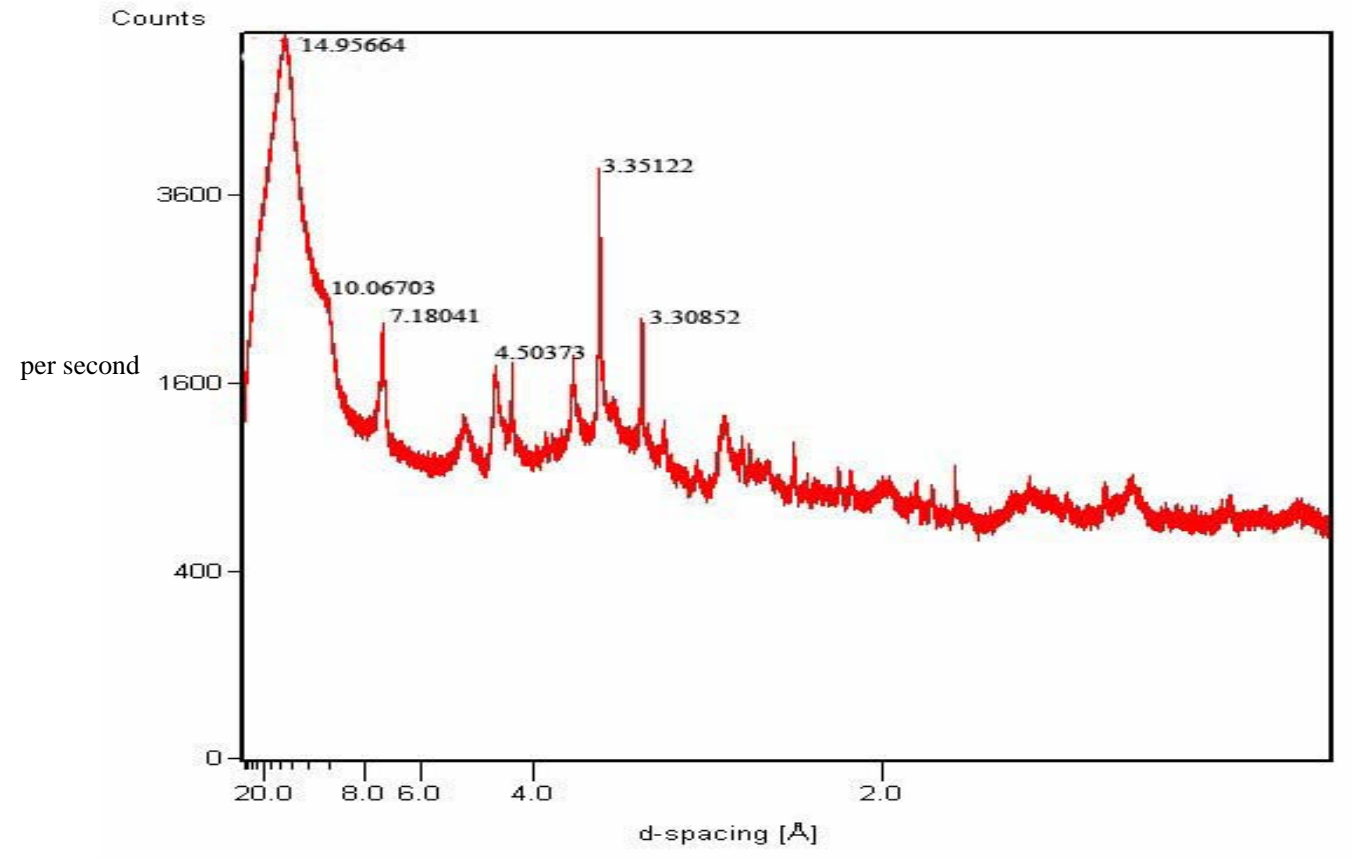

Figure 50: Sample B_51, from the garage pit, d-spacing and peaks for identified minerals.

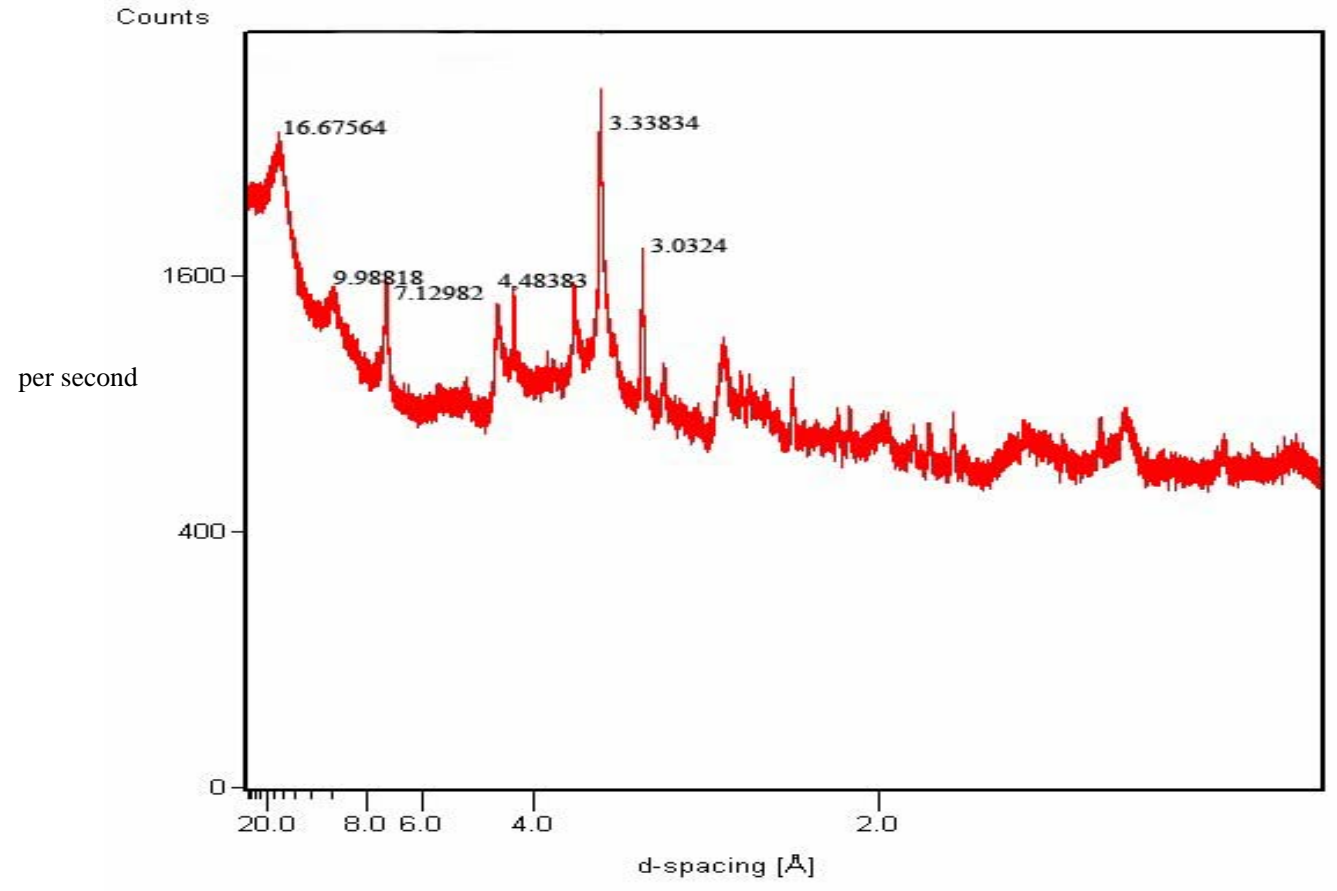

Figure 51: Sample B_51_A, from the garage pit, d-spacing and peaks for identified minerals after ethylene glycol treatment. Note shift in smectite peak. 


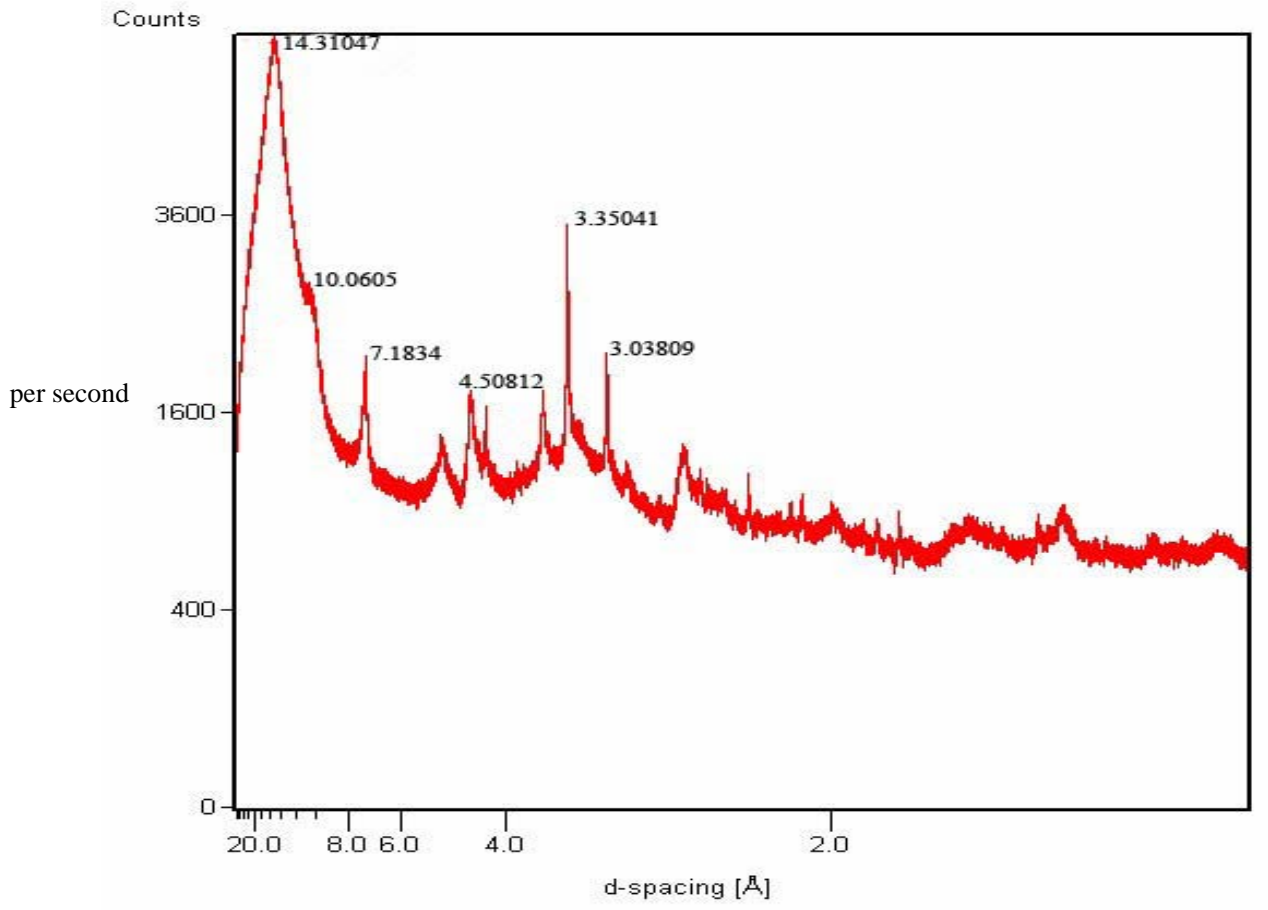

Figure 52: Sample DS_24, from Test Unit 1 A stratum, d-spacing and peaks of identified minerals.

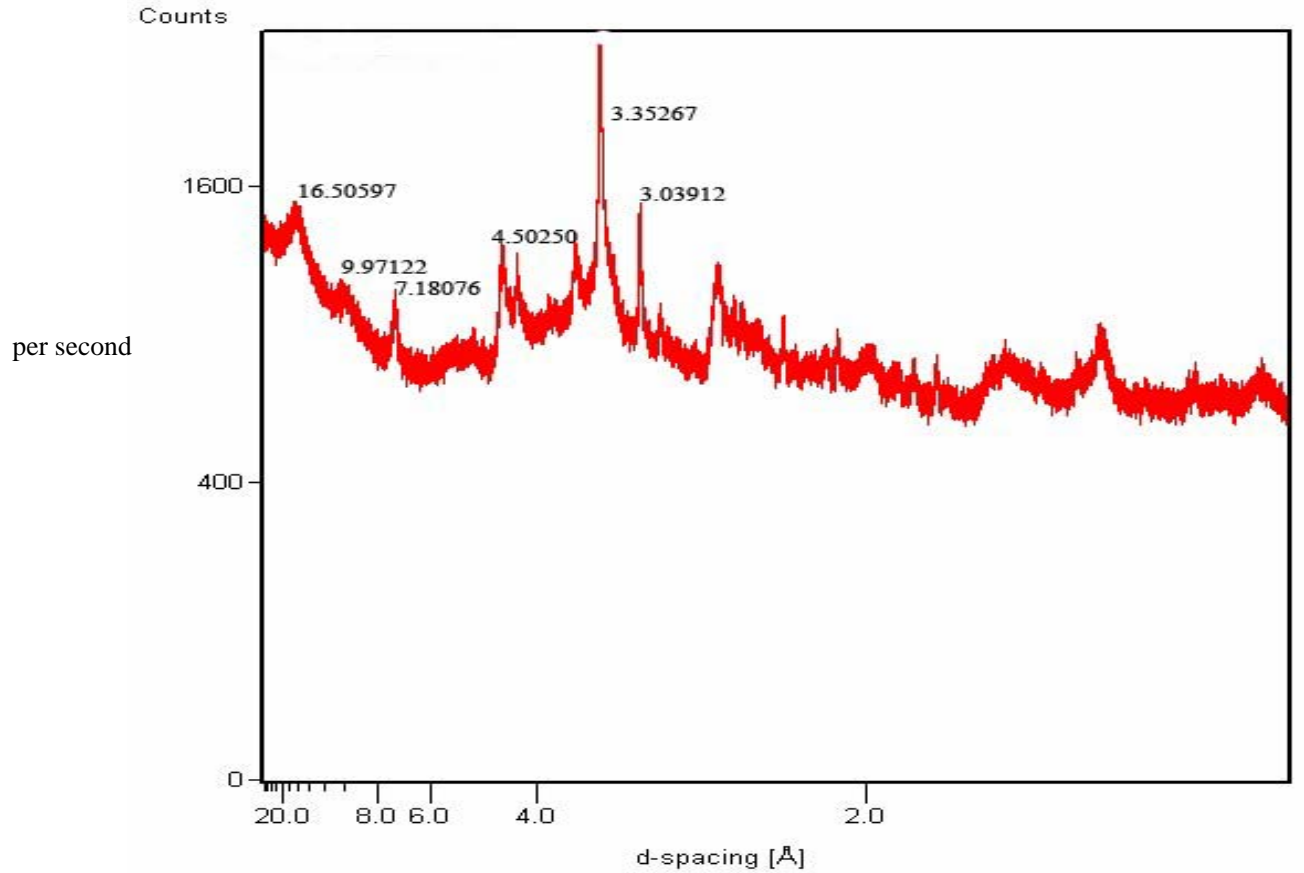

Figure 53: Sample DS_24_A, from Test Unit 1 A stratum, d-spacing and peaks of identified minerals after ethylene glycol treatment. Note shift in smectite peak. 


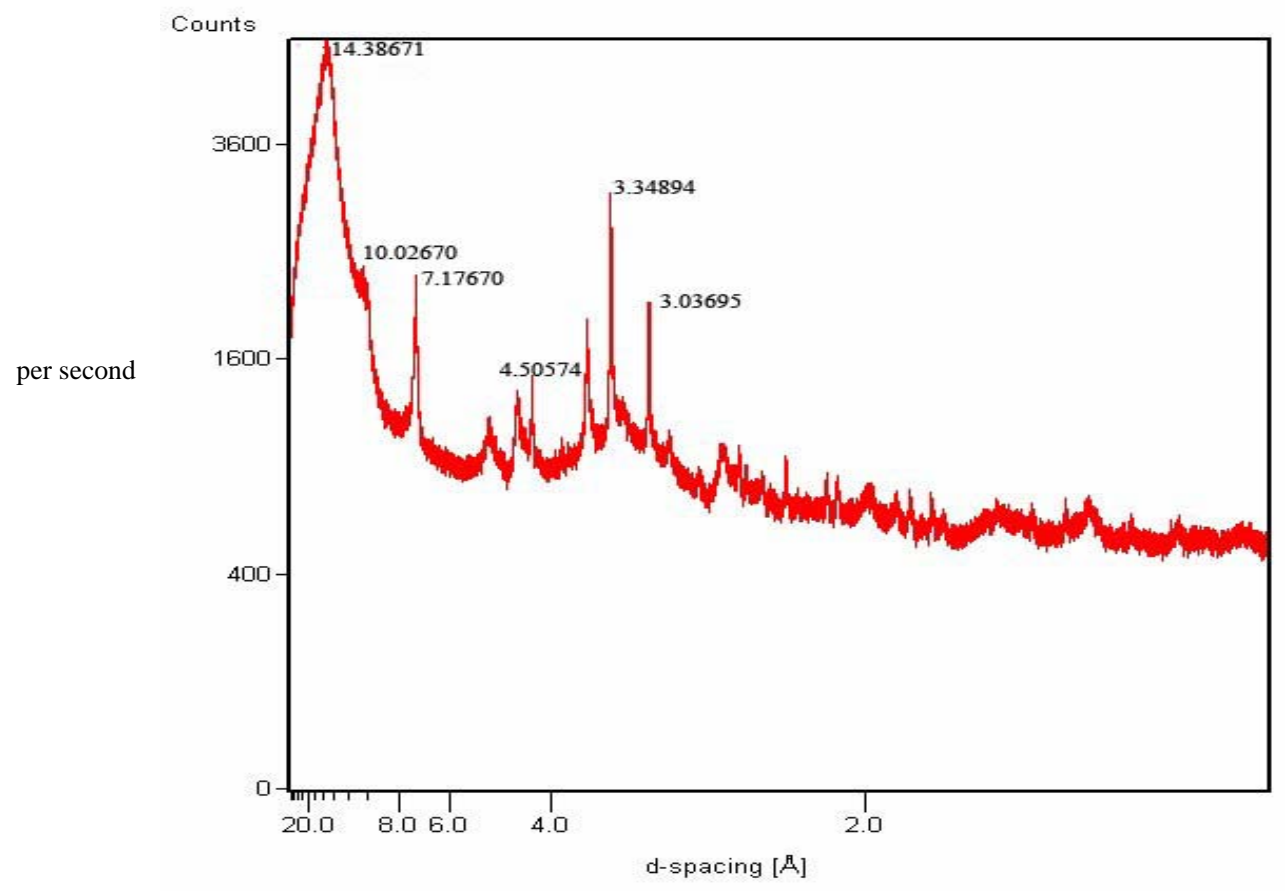

Figure 54: Sample E_1, from Test Unit 1 C stratum, d-spacing and peaks of identified minerals.

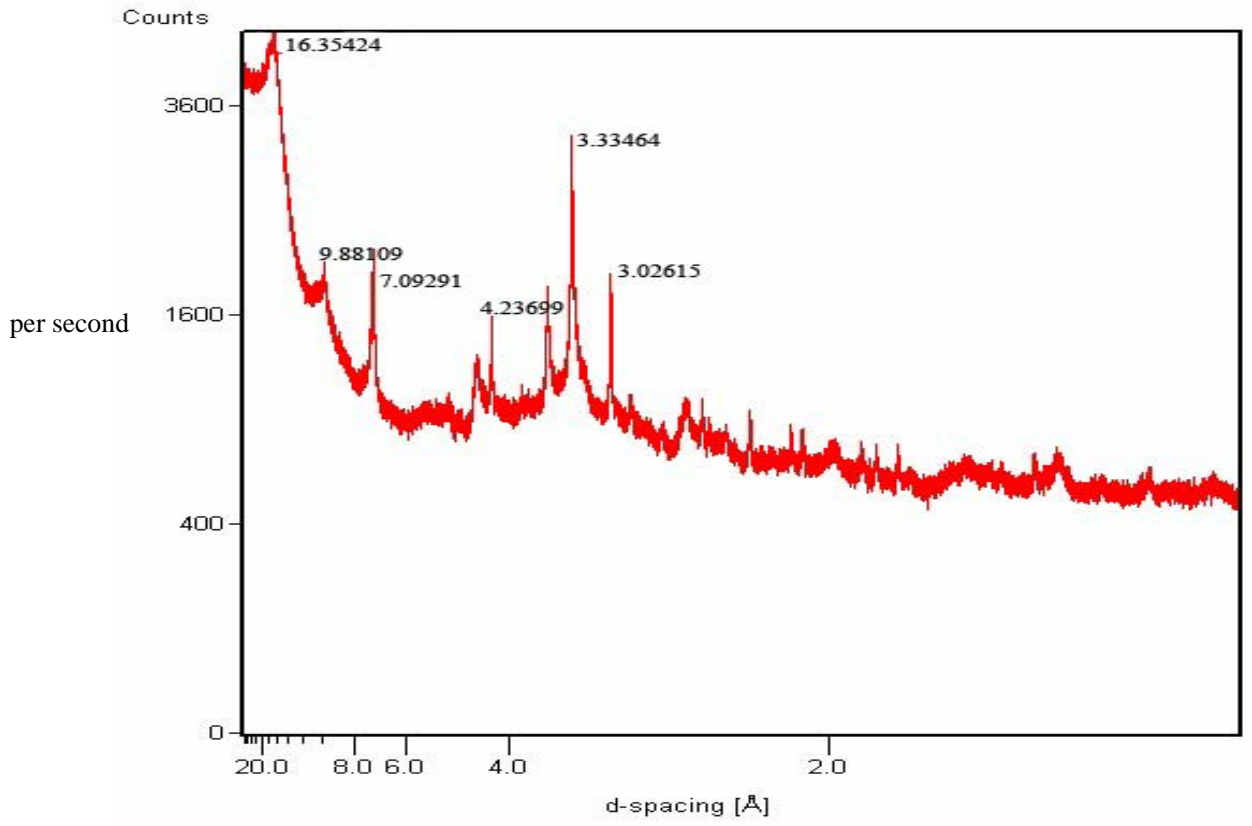

Figure 55: Sample E_1_A, from Test Unit 1 C stratum, d-spacing and peaks of identified minerals after ethylene glycol treatment. Notice shift in smectite peak. 
As shown in Figure 46 each sample had similar mineral and smectite peak patterns prior to glycolation. After glycolation each sample shifted its smectite peak, but other minerals retained similar profiles (Figure 47). Prior to glycolation $\sim 14 \AA$ peaks were found in each sample. After glycolation the peaks shifted to $\sim 16 \AA$ (Figures 48 to 55). These shifts are indicative of clay minerals with mixed layers containing predominantly smectites, and lesser amounts of vermiculite (Warshaw and Roy, 1961). The remaining peaks in each sample are identified as the following: $3 \AA$ and shorter peaks indicate either calcite or quartz; 3.3Å peaks indicate kaolinite; 4.2 to $4.5 \AA \AA$ peaks indicates

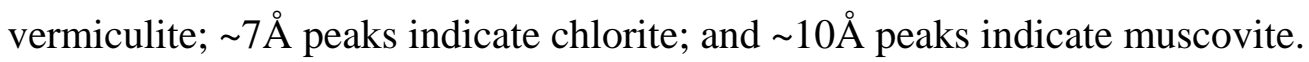




\section{Discussion}

St. Thomas is situated in a complex and dynamic environment that is exposed to several erosional and depositional processes that complicate attempts to interpret site formation. Any attempt to understand the site formation and degradation processes at St. Thomas is further complicated by six prior re-emergence episodes (Figure 12). These episodes, varying in their length of emergence, constitute additional erosional phases contributing to site destabilization.

This research has explored numerous possible sediment sources and processes contributing to deposition at St. Thomas yet no definitive source can be established. It is unlikely that the Colorado River is contributing significant amounts of sediment due to the distance and path the sediments would be required to travel up the remnant Virgin River Valley. It is probable that accumulated sediments within the St. Thomas structures are derived from uncompacted agricultural soil loosened during the initial flooding of St. Thomas and from seasonally highly turbid inflow currents associated with the Muddy River. Accumulated sediments outside the structures are sparse, but small low energy pools resulting from pool-level shallowing within the reservoir have created areas where fine grained material, such as silt and clay, can settle during times of highly turbid inflow.

Fieldwork has shown that the erosional processes at St. Thomas are operating at different scales. Small-scale processes are compromising landform stability and result primarily from pool-level shallowing caused by a decrease in snowfall in the Colorado Rockies that recharge Colorado River and its reservoirs, and also from the exploitation and overuse of water from urban expansion. Erosional processes like those operating on beaches, such as wave action, undercut structures and erode sediments from the re- 
emergent landscape. Biologic activity from tamarisk chokes out native species and break through foundations to destabilize the remaining structures. Human activity at St. Thomas during periods of re-emergence has thus far been negligible and is not considered a significant threat to site stability.

Large-scale erosional activity acting on a structure by structure basis further compromises the structural integrity of the remaining features. Extensive periods of exposure make the remaining structures susceptible to freeze-thaw weathering that causes spalling and cracking (Figure 19). As discovered during XRD analysis of sediment samples, the smectite content of deposited soils corresponds with physical evidence of structural cracking (Figure 39) and foundational warping (Figure 40). Smectities pose a degradational threat to feature stability due to their shrink-swell tendencies, that expand upon contact with rain water or when lake levels rise, and shrink when dryer conditions persist or lake levels decrease. In the long term, smectite expansion and contraction causes cracking and structural instability.

Together these processes are severely degrading the structural stability of the remaining features at St. Thomas. While submerged, the site is in a relatively static environment, but the structures become susceptible to degradation during re-emergence. Most of the remaining features are in poor condition and show visible signs of degradation from the aforementioned processes. Prescriptive measures to reduce erosion within a site such as St. Thomas are limited. Lake Mead NRA has made attempts to reduce erosion and increase site accessibility through controlled burns to remove tamarisk. This method has proven effective in creating trails to St. Thomas and paths to selected structures. However, this method can have adverse effects if not properly 
monitored and controlled. A massive burn of the entire landscape is not suggested. No other erosion deterrents have been attempted. The uncertainty whether water levels will once again rise and submerge St. Thomas, as historical trends have indicated, make it difficult for park officials to spend costly time and resources on endeavors that could be lost if water levels increase.

Research thus far suggests that the current environmental conditions in place will not lead to successful preservation, and climatic uncertainty deters possible preservation plans. To date, the Cultural Resource Management Team at Lake Mead NRA has devoted countless man hours recording and documenting the remaining structures at St. Thomas and contacting previous residents. Whether St. Thomas becomes submerged once again is unsure, but the data collected and generated by this research and the U.S. National Park Service will ensure a more complete understanding of the processes and mechanisms operating at St. Thomas if submergence and re-emergence continue in the future. 


\section{Conclusions}

Dam construction is and continues to be one of the most destructive mechanisms erasing human history and prehistory. Sandouping in China, the site chosen for the construction of Three Gorges Dam, the largest hydroelectric plant in the world, will regulate the Yangtze River. This huge dam is the most recent example of massive human displacement and cultural loss that societies are experiencing on behalf of water regulation. Often these losses could be guarded against, but, organizations such as the World Bank, who sponsor many hydroelectric projects throughout the world, do not enforce or ensure that archaeological investigations or thorough environmental impact displacement studies are conducted prior to reservoir filling, as occurred during the construction of the Urral Dam on the upper Sinu River in Colombia.

Within the United States dams such as Hoover, Grand Coulee, Glen Canyon and Kinzua have submerged millions of acres and thousands of cultural sites. However, if current environmental conditions persist and dam removal becomes an option for stream restoration, more sites will re-emerge and be susceptible to many of the erosional processes operating at St. Thomas. Perhaps in the future, sites submerged by the Three Gorges Dam, Urral Dam, Glen Canyon and etc. will also face this peril; as time has shown, damming is only a short term fix to long term societal problems.

St. Thomas is not an isolated phenomenon, reservoir down-draw is occurring in lakes throughout the United States from Lake Powell, Arizona, to Table Rock Lake, Missouri. Resource managers must be prepared to prescribe preservation measures for re-emerged cultural resources, whether temporarily or permanently re-emerged. This research is an initial stepping-stone providing insight into the erosional mechanisms and processes 
operating in sites located in areas experiencing environmental changes and climatic

fluctuation. Once these processes are identified, conservation and preservation management plans can be created and implemented to ensure that the cultural heritage, history and education about these places will not be obscured by urban development, but will persist into the future. 


\section{References Cited}

Abbey, E., 1971. Beyond the Wall. New York, Henry Holt and Company, LLC.

Allen, J. and Simmon, R., 2003. Drought Lowers Lake Mead. NASA Earth Observatory. http://earthobservatory.nasa.gov/Study/LakeMead/

Bayer, P., 2005, Journal of Geomorphology Special Edition 71: 27-47.

Blalock, H.N. and Herod J.J.,1999, A Comparative Study Of Stream Habitat And Substrate Utilized By Corbicula Fluminea In The New River, Florida. Florida Scientist 62:145-151.

Brandt, S. and Hassan, F., 2000, Dams and Cultural Heritage Management. Cape Town, South Africa, World Commission on Dams.

Brandt, S. A. and Hassan, F.A., yet to be released, Damming the Past: Dams and Cultural Heritage Management. Lanham, MD, Lexington Publishing.

Brink, E., 2004, Beyond Dams: Options and Alternatives. A report by American Rivers and International Rivers Network. http://www.irn.org/basics/alternatives/pdf/BeyondDams.Intro.Overview.pdf

Brown, E., Park, D. and Wright, J.,1999, Waves, Tides and Shallow-Water Processes. Oxford, The Open University.

Carpenter, A. T.,1998, Element Stewardship Abstract. Boulder, Colorado, The Nature Conservancy.

Covay, K. and Beck, D., 2001, Sediment-Deposition Rates and Organic Compounds in Bottom Sediment at Four Sites in Lake Mead, Nevada, May 1998, U.S. Geological Survey Open-File Report 01-282. http://pubs.usgs.gov/of/2001/ofr01282/.

Darron, S., 2006, Archaeologist Lake Mead National Recreation Area. Boulder City: Nevada.

Davis, C. V. and Sorensen, K.E.,1969, Handbook of Applied Hydraulics. New York, McGraw-Hill.

Gould, H. R., 1948, Turbidity Currents: U.S. Geological Survey Professional Paper 295, p. 201-207.

Gould, H. R., 1948, Character of the Accumulated Sediment: U.S. Geological Survey Professional Paper 295, p. 149-186. 
Graf, W.L., 2005, Geomorphology and American dams: The scientific, social, and economic context.: Geomorphology 71: 3-26.

Grubb, R., Sheley, R. and Carlstrom,.R., 2002, Saltcedar (Tamarisk). Montana State University Extension Service. http://www.montana.edu/wwwpb/pubs/mt9710.html.

Gushu, S., 2005, Lake Mead National Recreation Area. Boulder City, Nevada.

Hafner, A. L., 1967, 100 Years on the Muddy. Springville, Utah, Art City Publishing Company.

Howard, C. S., 1948, Water of the Lake: U.S. Geological Survey Professional Paper 295, p. 103-146.

Jensen, E., Oral Communication January 2006. Archeologist/Curator I Lost City Museum Overton, Nevada.

Kite, J.S. and Bell, A., 1992, Particle-size analysis at the Quaternary Geology Laboratory, Morgantown, WV, West Virginia University.

Knighton, D., 1998, Fluvial Forms and Processes A New Perspective. Arnold, London.

Koelzer, V., 1969, Reservoir Hydraulics. Handbook of Applied Hydraulics. Sorensen. New York, McGraw Hill: 4-1 through 4-24.

Leifson, G., 1948, Survey of the Lake: U.S. Geological Survey Professional Paper 295, p. 39-81.

Lenihan, D., Carell, T., Fosberg, S., Murphy, L., Rayl, S. and Ware, J., 1981, The Final Report of the National Reservoir Inundation Study. Technical Reports. Santa Fe, New Mexico, United States Department of the Interior National Park Service Southwest Cultural Resources Center.

Leopold, L., 1994, A View of the River. Cambridge, Massachusetts, Harvard University Press.

Longwell, C.R., 1936, Bulletin of the Geological Society of America. Plates 2-4: Volume 47. University of Las Vegas Lied Special Collections Library.

Longwell, C. R., 1948, Geologic Setting of Lake Mead: U.S. Geological Survey Professional Paper 295, p. 11-20. 
Mansfield, G.R., 1937, Flood deposits of the Ohio River, January-February 1937. U.S. Geological Survey Water-Supply Paper 837.

McClellan, C., Phillips, D. and Belshaw, M., 1980, The Archaeology of Lake Mead National Recreation Area: An Assessment. Tucson, Arizona, Western Archeological Center.

Morris, G. L. and Fan, J., 1998, Reservoir Sedimentation Handbook, Design and Management of Dams, Reservoirs, and Watersheds for Sustainable Use: New York, McGraw-Hill.

Petts, G.E., 2005, Dams and geomorphology: Research progress and future directions. Geomorphology 71: 27-47.

Thomas, H. E., 1948, Drainage Basin Tributary to Lake Mead: U.S. Geological Survey Professional Paper 295, p. 21-30.

Thorne, R., 1991, Site Stabilization Information Sources. Washington D.C., DOI Departmental Consulting Archaeologist/NPS Archaeology and Ethnography Program. http://www.cr.nps.gov/archaeology/pubs/techbr/tch12A.htm.

Thorne, R., 2004, Protecting Archaeological Sites on Eroding Shorelines: A Hay Bales Approach. R. Thorne. Washington D.C., DOI Departmental Consulting Archaeologist/NPS Archaeology and Ethnography Program. http://www.cr.nps.gov/archaeology/pubs/techbr/tch/18A.htm.

Trimble S. W., 1983, A Sediment Budget for Coon Creek Basin in the Driftless Area, Wisconsin, 1853-1977: American Journal of Science, v. 283, p. 454-474.

Twichell, D. C., Cross, V.A. and Belew, S.D., 2003, Mapping the floor of Lake Mead (Nevada and Arizona): Preliminary discussion and GIS data release, Woods Hole U.S. Geological Survey Open-File Report 03-320. http://pubs.usgs.gov/of/2003/of03-320/htmldocs/geology.htm.

Ulirsch, G., Hayes, L. and Chute, S., 2002, Public Health Implication of Direct Exposure to Byram River Sediment: Greenwich, Fairfield County, Connecticut. Connecticut Department of Public Health and Agency for Toxic Substances and Disease Registry. http://www.atsdr.cdc.gov/HAC/PHP/byramriver/byr_p1.html.

U.S. Army Corps of Engineers, 1993, The Great Flood of 1993 Post-Flood Report. North Central Division. http://www.mvr.usace.army.mil/PublicAffairsOffice/HistoricArchives/Flood of1993/pafr.htm. 
U.S. Army Corps of Engineers, 2006, National Inventory of Dams. http://www.crunch.tec.army.mil/nid/webpates.nid.cfm.

U.S. Department of Agriculture, 2006, Natural Resource Conservation Service Official Soil Series Descriptions. http://ortho.ttw.nrcs.usda.gov/cgi-bin/osd/osdname.cgi

U.S. Geological Survey, 2005. National Map. http://www.nationalmap.gov.

U.S. National Parks Service, 2006, Official Lake Mead Expanded Web Page: Scuba Scuba Diving. http://www.nps.gov/lame/scuba.html.

Warshaw, C. M. and Roy, R., 1961, Classification and a scheme for the identification of layer silicates. Geological Society of America Bulletin 72: 14551492. 
Appendix

\begin{tabular}{||l|r|r|r|r|r||}
\hline & $\begin{array}{c}\text { Gravel } \\
>2000(\mu \mathrm{m})\end{array}$ & $\begin{array}{c}\text { Sand } \\
2000 \text { to 62.5 } \\
(\mu \mathrm{m})\end{array}$ & $\begin{array}{c}\text { Silt } \\
62.5 \text { to } 3.9 \\
(\mu \mathrm{m})\end{array}$ & $\begin{array}{c}\text { Clay } \\
<3.9(\mu \mathrm{m})\end{array}$ & $\begin{array}{c}\text { Total } \\
\text { Weight }\end{array}$ \\
\hline $\begin{array}{l}\text { Test Unit 1 A } \\
\text { Stratum DS_24 }\end{array}$ & $1.62 \mathrm{~g}$ & $52.71 \mathrm{~g}$ & $4.93 \mathrm{~g}$ & $1.88 \mathrm{~g}$ & $\mathbf{6 1 . 1 4 \mathrm { g }}$ \\
\hline $\begin{array}{l}\text { Feature 6 } \\
\text { C StratumTT_3 }\end{array}$ & $1.44 \mathrm{~g}$ & $12.53 \mathrm{~g}$ & $50 \mathrm{~g}$ & $11.67 \mathrm{~g}$ & $75.64 \mathrm{~g}$ \\
\hline $\begin{array}{l}\text { Test Unit 1 } \\
\text { C Stratum E_1 }\end{array}$ & $1.46 \mathrm{~g}$ & $53.41 \mathrm{~g}$ & $31.76 \mathrm{~g}$ & $16.03 \mathrm{~g}$ & $102.66 \mathrm{~g}$ \\
\hline $\begin{array}{l}\text { Garage Pit } \\
\text { C Stratum B_51 }\end{array}$ & $1.9 \mathrm{~g}$ & $52.76 \mathrm{~g}$ & $14.96 \mathrm{~g}$ & $6.77 \mathrm{~g}$ & $76.39 \mathrm{~g}$ \\
\hline
\end{tabular}

Weights of gravel, sand, silt and clay fractions after wet sieving sediment sample.
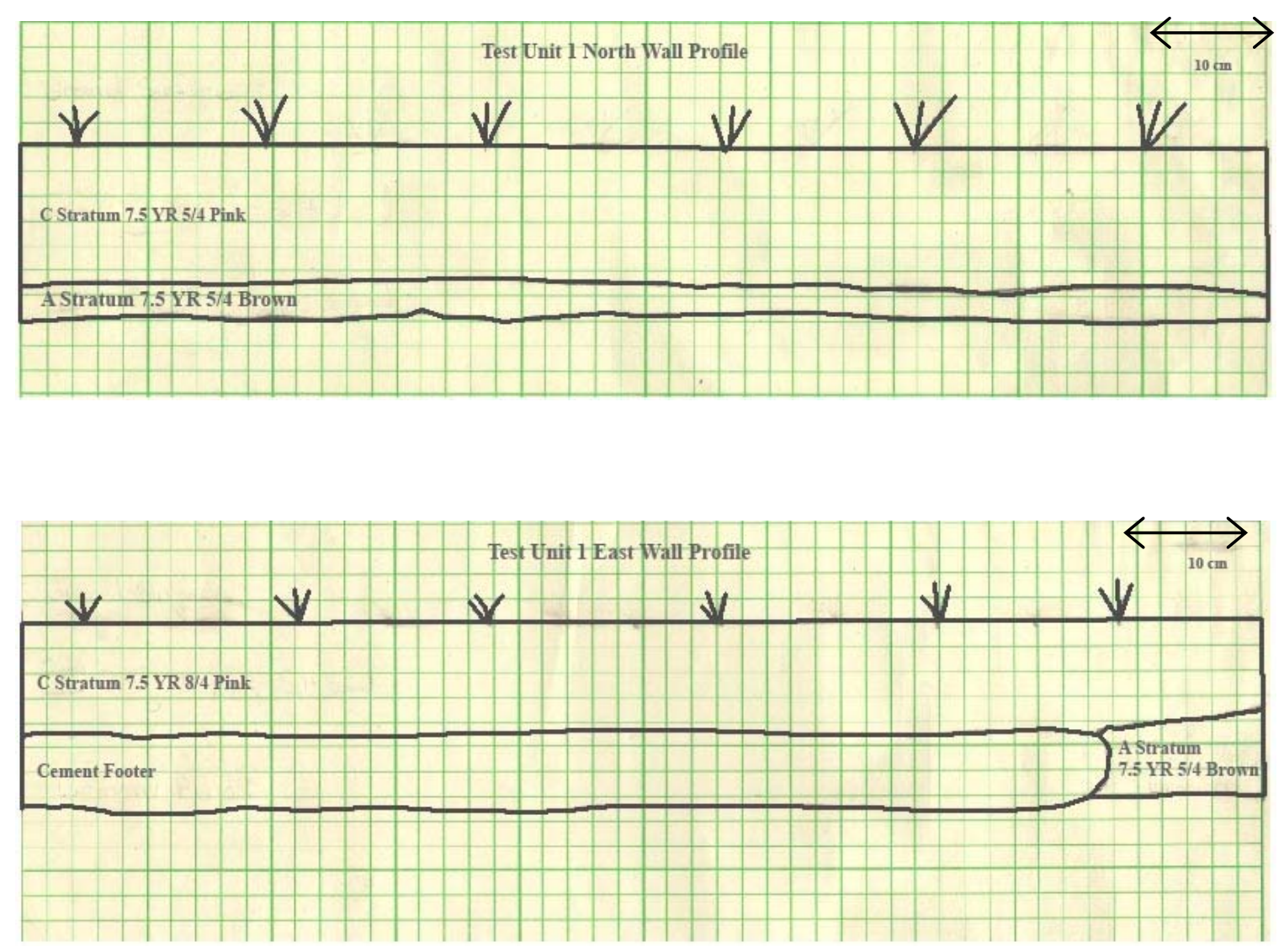

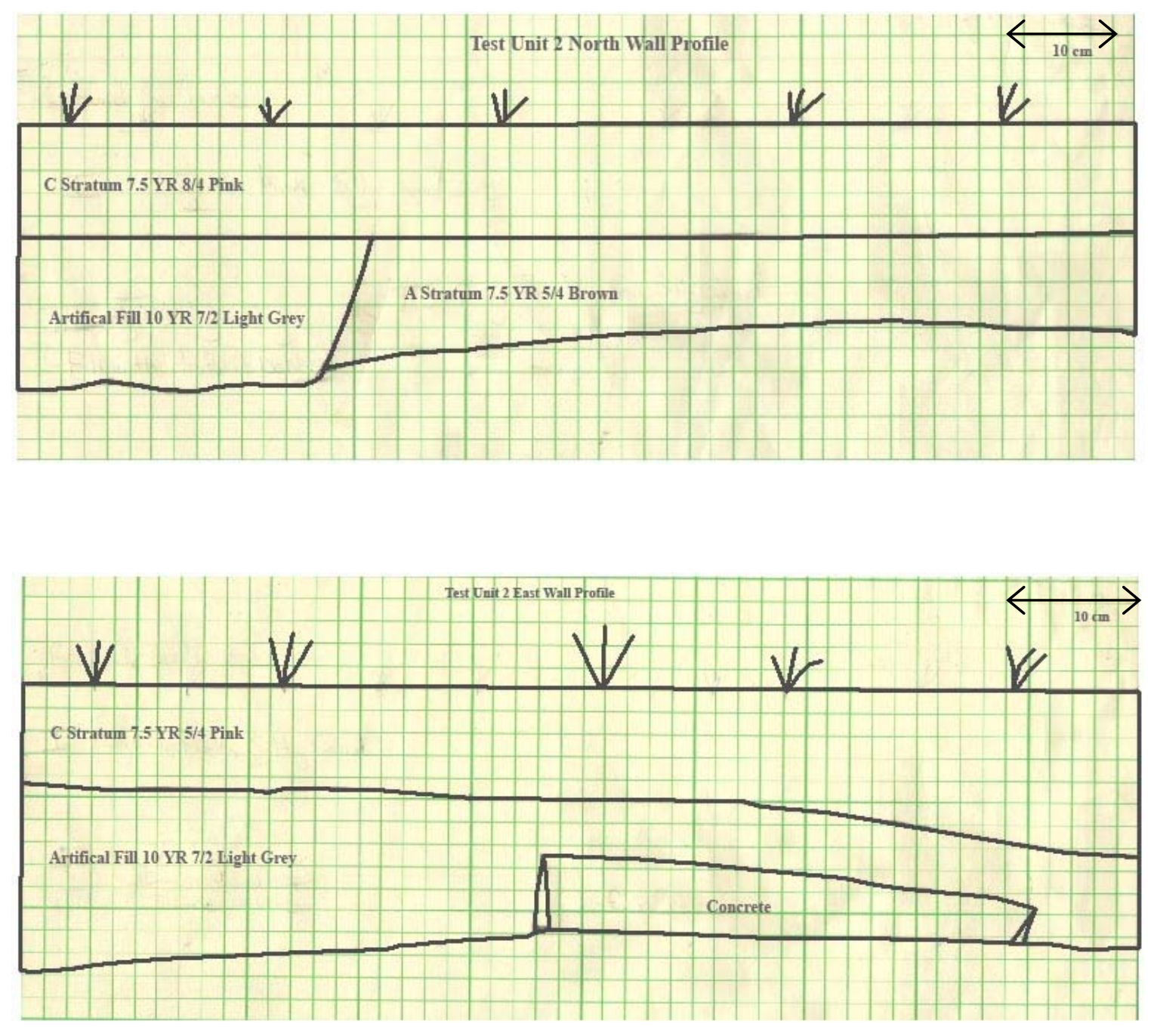